U.S. Department of the Interior

U.S. Geological Survey

\title{
Flood Potential of South Prairie Creek, Pierce County, Washington
}

Water-Resources Investigations Report 98-4009

U.S. Department of the Interior

U.S. Geological Survey

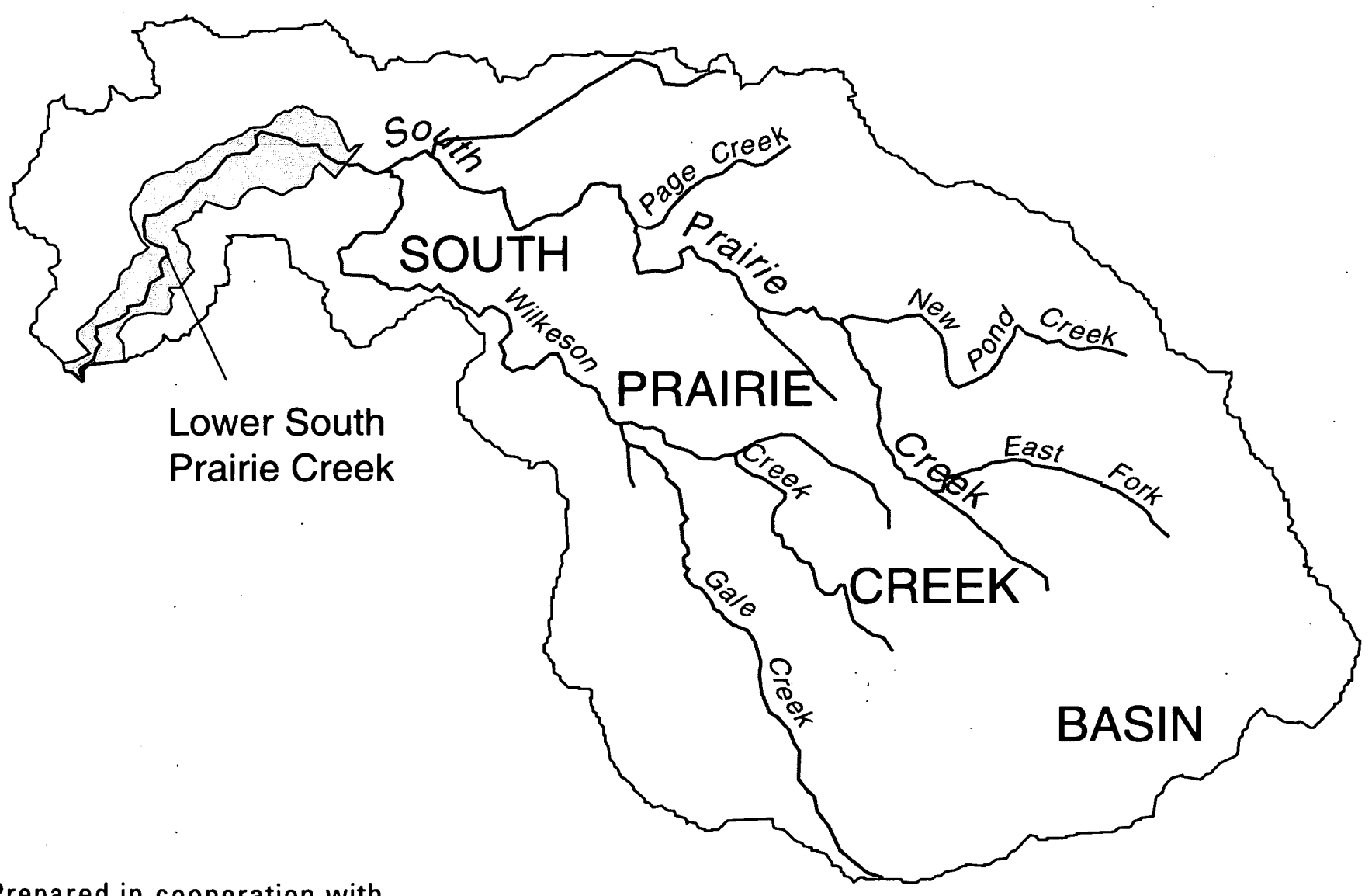

Prepared in cooperation with

Pierce County Department of Public Works

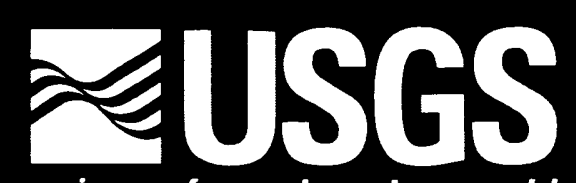




\section{Flood Potential of South Prairie Creek, Pierce County, Washington}

By M.C. Mastin

U.S. Geological Survey

Water-Resources Investigations Report 98-4009

Prepared in cooperation with

PIERCE COUNTY DEPARTMENT OF PUBLIC WORKS

Tacoma, Washington

1998 


\section{U.S. DEPARTMENT OF THE INTERIOR \\ BRUCE BABBITT, Secretary}

\section{U.S. GEOLOGICAL SURVEY}

Thomas J. Casadevall

Acting Director

Any use of trade, product, or firm names is for descriptive purposes only and does not imply endorsement by the U.S. Government.

For additional information write to:

Copies of this report may be purchased from:

District Chief

U.S. Geological Survey

1201 Pacific Avenue - Suite 600

Tacoma, Washington 98402
U.S. Geological Survey

Branch of Information Services

Box 25286

Denver. Colorado 80225-0286 


\section{CONTENTS}

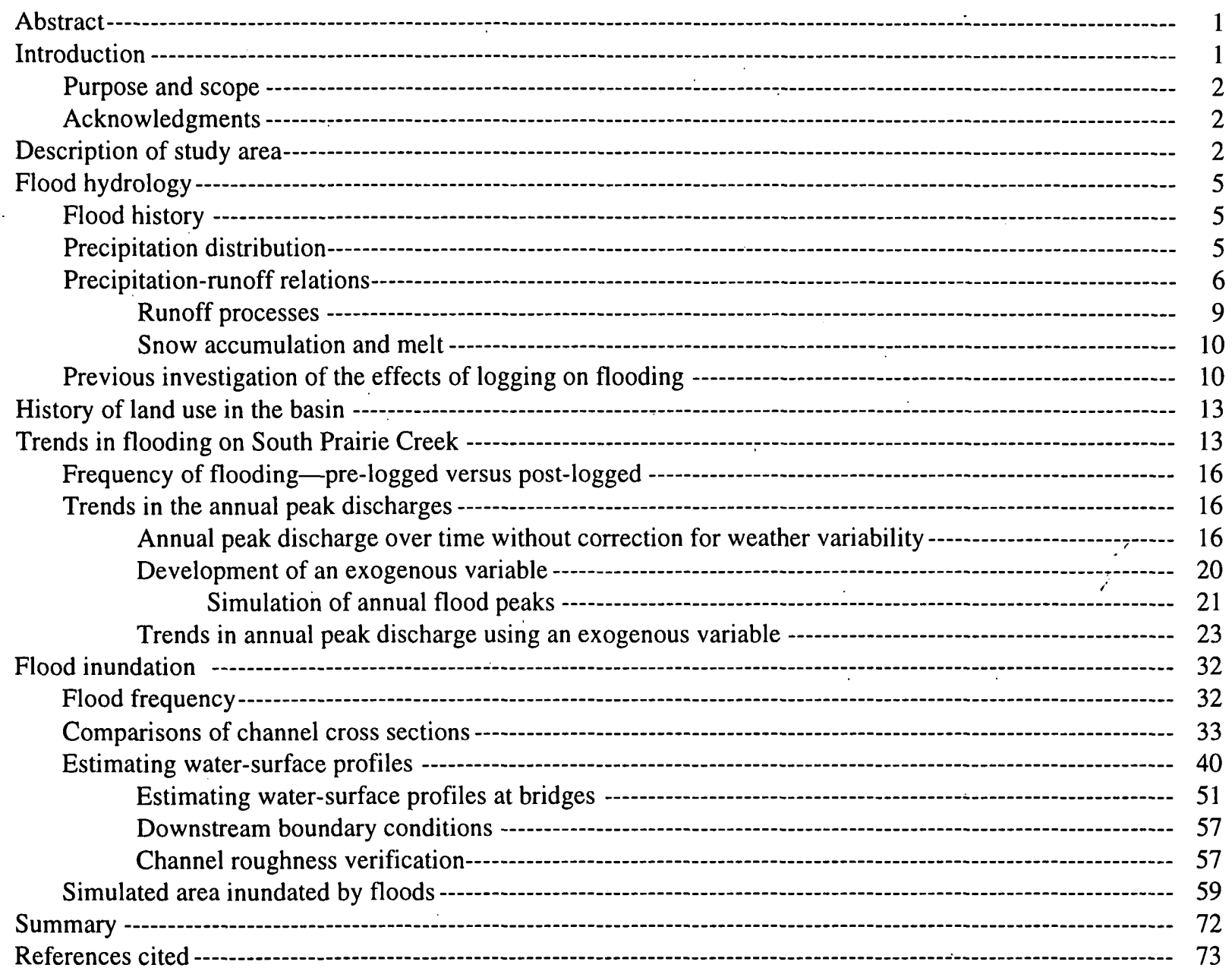

\section{FIGURES}

1. Map showing study area showing South Prairie Creek and its basin boundaries and the Puyallup River system and its basin boundaries

2. Map showing lower South Prairie Creek, showing the approximate extent of the valley floor, the stream-gaging station, and the confluence with the Carbon River

3. Map showing South Prairie Creek Basin, nearby weather stations, and mean annual precipitation

4. Graph showing mean annual precipitation as a function of elevation in South Prairie Creek Basin, Washington

5. Hydrographs showing discharge at South Prairie Creek (station no. 12095000) and precipitation at Mud Mountain Dam for two storms in 1994-

6. Maps showing clearings and roads determined from aerial photo interpretation, South Prairie Creek Basin, Washington-

7. Graph showing area of clearings and length of roads in South Prairie Creek Basin from 1965 to 1990

8. Graph showing number of times per year that peak discharge exceeds 1,400 cubic feet per second for two periods, pre-logging (1950-71) and post-logging (1988-96) for South Prairie Creek at South Prairie, Washington- 


\section{FIGURES--Continued}

9. Graph showing the distribution of the number of peaks above base discharge per water year for the post-logging and pre-logging periods for South Prairie Creek at South Prairie, Washington -

10. Time series graph showing observed annual peak discharge at South Prairie Creek at South Prairie, Washington

11. Graphs showing observed and simulated discharge and basin-averaged rain and snowmelt for February 4-10, 1996, at South Prairie Creek (Station No. 12095000)

12. Graph showing observed and simulated annual peak discharge of South Prairie Creek (station number 12095000) during water years 1950-79 and 1988-96-

13-14. Time series graphs showing:

13. Residuals from the model of South Prairie Creek at South Prairie, Washington

14. Residuals from regression of observed annual peak discharge with simulated annual peak discharge of South Prairie Creek at South Prairie, Washington -

15. Graph showing Locally Weighted Scatterplot Smoothing (LOWESS) regression of observed annual peak discharge against simulated annual peak discharge of South Prairie Creek at South Prairie, Washington

16. Time series graph showing residuals of Locally Weighted Scatterplot Smoothing (LOWESS) fit of observed with simulated annual peak discharges of South Prairie Creek at South Prairie, Washington

17. Time series plots showing annual precipitation and mean temperature from 1950 to 1995 at four National Weather Service stations in Pierce County, Washington

18. Graph showing annual peak flow frequency for South Prairie Creek at South Prairie Washington (station number 12095000)

19. Index to maps (fig. 20-23 and 41-44) of lower South Prairie Creek, Washington --a-c-o- 35

20-23. Maps showing cross-section locations on lower South Prairie Creek, Washington:

20. Map 1 of 4-- 36

21. Map 2 of 4-- 37

22. Map 3 of 4-.-1-.- 38

23. Map 4 of 4-a

24-26. Channel cross sections on South Prairie Creek:

24. At the downstream end of Washington State Route 162, Bridges 1 and 2

25. At the downstream end of Washington State Route 162, Bridges 3 and 4

26. At the downstream end of Washington State Route 162, Bridge 5 and downstream end of the railroad bridge, Bridge 6

27-29. Exit and approach floodplain and channel cross sections, at Washington State Route 162 over

South Prairie Creek, to:

27. Bridge 3

28. Bridge 4

29. Bridge 5

30-33. Floodplain and channel cross sections on South Prairie Creek:

30. Cross sections 10 and 20

31. Cross sections 240 and 250

32. Cross sections 275 and 280

33. Cross sections 380 and 390

34. Graphs showing overflow rating curves for cross sections OVRFL3 and OVRFL5,

South Prairie Creek, Washington

35. Graphs showing simulated water-surface profiles for five discharges computed as freesurface flow or orifice flow in the vicinity of Bridge 5 on South Prairie Creek, Washington

36. Graphs showing beginning water-surface profiles from cross sections 10 to 50 for discharges for the 10-, 50-, 100-, and 500-year floods on South Prairie Creek, Washington 


\section{FIGURES--Continued}

37-40. Graphs showing step-backwater water-surface profiles for South Prairie Creek, Washington from:

37. Cross section 10 to $110-$

38. Cross section 110 to EXIT3 - 64

39. Cross section EXIT3 to 340 - 65

40. Cross section 340 to 440 -.-. 66

41. Map of lower South Prairie Creek, Washington, showing areas of inundation for the 100- and 500-year floods, area of shallow flooding, and cross-section locations (Map 1 of 4) --------- 67

42-44. Maps of lower South Prairie Creek, Washington, showing areas of inundation for the 100- and 500 -year floods and cross-section locations --- 68

42. Map 2 of 4-10 68

43. Map 3 of 4- 4 - 69

44. Map 4 of 4---on 70

45. Map of the vicinity of Spring Site Road showing cross sections used in the step-backwater model, the areas of inundation for the 100-and 500-year floods, and elevations surveyed on November 12, 1996-

\section{TABLES}

1. Annual peak discharge and relative rank for South Prairie Creek at South Prairie, Washington, for water years 1950 through 1996

2. Five-day precipitation totals and the percent of mean annual precipitation for two storms for several nearby U.S. Geological Survey and National Weather Service stations -

3. Two annual peak discharges, 3-day basin precipitation, and 3-day snow-melt index contrasting the influence of snowmelt on peak discharges in South Prairie Creek Basin, Washington

4. Results of linear regression of the annual peak discharges, in cubic feet per second, at South Prairie Creek (U.S. Geological Survey station number 12095000) with the 5-, 3-, and 1-day precipitation totals for the indicated National Weather Service stations

5. Observed and simulated annual peak discharges and their difference, 3-day simulated basin-averaged rain, and 3-day simulated snowmelt totals for water years 1950 to 1979 and 1988 to 1996 at South Prairie Creek at South Prairie, Washington

6. Results of multiple linear regression of observed annual peak discharge with water years and simulated peak discharge -

7. Results of linear regression of year with annual precipitation and annual mean temperature and Mann-Kendall trend test with the available record at four National Weather Service stations for calendar years 1950-95 in or near the South Prairie Creek Basin, Washington-

8. Selected annual peak flow exceedance probabilities for South Prairie Creek at South Prairie, Washington (Station number 12095000)

9. Cross-section identifiers, stationing upstream of the mouth, and year of field survey for cross-section data for South Prairie Creek, Washington

10. Elevations of high water marks surveyed near indicated cross sections and water-surface elevations from $n$-verification step-backwater runs for two peaks on South Prairie Creek, Washington

11. Cross-section identifiers, stationing above the mouth, minimum streambed elevations, and step-backwater results showing estimated water-surface elevations and the discharge corresponding to the 10-, 50-, 100-, and 500-year floods for South Prairie Creek, Washington 


\section{VERTICAL DATUM}

Sea Level: In this report "sea level" refers to the National Geodetic Vertical Datum of 1929 (NGVD of 1929)--a geodetic datum derived from a general adjustment of the first-order level nets of both the United States and Canada, formerly called Sea Level Datum of 1929. 


\title{
FLOOD POTENTIAL OF SOUTH PRAIRIE CREEK, PIERCE COUNTY, WASHINGTON
}

\author{
By M. C. Mastin
}

\begin{abstract}
South Prairie Creek, Wash., has experienced several large, destructive floods in the last few years that have caused concern from some residents that the potential for flooding on the creek has increased in recent years because of clear-cut logging and timber-access road construction in the upper watershed. Analysis of aerial photo data from 1965 to 1990 indicated that the percentage of basin area that has been cleared and the total mileage of roads in the basin have dramatically increased. Clearings increased from 11.2 percent of the total area in 1965 to 34.5 percent in 1990. Road length, which was 119.6 miles in 1965 , grew to 237.0 miles by 1990 . Although current literature suggests that increases in clearings and road length may increase peak runoff, no statistically significant trend was detected in the 39 years of annual peak-discharge data recorded at the South Prairie Creek at South Prairie gaging station. In the statistical analysis, a watershed model simulated the 39 annual peak discharges while holding all the runoff parameters constant throughout the simulations. Simulated peak discharge was used as an exogenous variable in both parametric and non-parametric statistical tests for trends. The mean of the annual number of peaks above a base discharge of 1,400 cubic feet per second is higher (3.3) in recent times (1988-96) than the mean (2.5) in the past (1950-71), but the difference is not statistically significant at the 5-percent level.
\end{abstract}

A log-Pearson Type III flood frequency analysis of the 39 years of annual peak discharge at the South Prairie Creek gage determined the 10-, 50-, 100-, and 500-year floods to be 5,$520 ; 7,910 ; 8,960$; and 11,500 cubic feet per second, respectively.
Comparison of flood-plain and channel-cross-section data surveyed for a flood insurance study in 1976-77, for this investigation in 1995, and again for this investigation after the peak-of-record flooding in 1996 indicates little change in the channel or flood-carrying capacity. These cross-section data were used in a numerical step-backwater model to determine the water-surface profiles for the 10-, 50-, 100-, and 500-year floods. Areas of flood inundation along the lower part of South Prairie Creek for the 100- and 500-year floods were delineated using the calculated water-surface profiles in conjunction with available topographic maps. Flooding of the Town of South Prairie is estimated to occur only for the 500-year flood as shallow, wide-spread flooding, whereas overbank flooding downstream of the town is estimated to occur more frequently.

\section{INTRODUCTION}

Recent flooding on South Prairie Creek, Pierce County, Wash., especially in January 1990 and February 1996, has caused considerable damage to many homes, farms, roads, and levees along the lower part of South Prairie Creek. There is concern that the frequency of floods in the basin is increasing and suspicion has fallen on land-use practices, especially timber harvesting and timber-access road building in the upper portions of the watershed, for creating or contributing to conditions that increase flooding on South Prairie Creek. Also, timber harvesting, which has probably increased erosion in the upper watershed, may have resulted in increased deposition of sand and gravel in the downstream channel, thereby reducing the capacity of the channel to convey floodwaters. 
The Surface Water Management Utility (SWM) within the Pierce County Department of Public Works is responsible for reducing hazards and property damage that flooding may cause. Design and engineering for land-use planning near streams and rivers in general rely on information collected during flood insurance studies published by the Federal Emergency Management Agency (FEMA) that define flood-risk data within the floodplains. The most recent flood-insurance study on South Prairie Creek (Federal Emergency Management Agency, 1987) was generated from cross-sectional data surveyed in 1976 and 1977. Because sufficient time has passed since the last study to justify incorporating new annual peak-flow data, a renewed investigation to define the flood risk and associated flood elevations on South Prairie Creek was warranted. There was also the possibility of significant channel change due to the recent passage of the largest and fourth largest recorded floods and the possibility of increased sedimentation due to the ongoing timber harvesting during the last two decades. To address these concerns, the U.S. Geological Survey (USGS) in cooperative agreement with SWM conducted this investigation of the potential flooding on the lower floodplain of South Prairie Creek.

\section{Purpose and Scope}

The purposes of this report are to (1) describe the important aspects of flood hydrology in the basin, (2) describe the recent history of land use in the basin, (3) describe any trend in flooding that may exist, (4) define the frequency of flooding in terms of the 10-, 50-, 100-, and 500-year floods, and (5) describe the areas of inundation for these floods along the lower South Prairie Creek floodplain from the Town of South Prairie to the mouth of the creek.

\section{Acknowledgments}

The author thanks the citizens of Pierce County along South Prairie Creek who allowed access to their property to survey channel and floodplain cross sections and high water marks left from the February 19, 1995, and February 8, 1996, peak flows.

\section{DESCRIPTION OF STUDY AREA}

South Prairie Creek Basin lies in the heart of the Puyallup River Basin on the west side of the Cascade Mountains in the foothills just northwest of Mt. Rainier (fig. 1). The basin has a drainage area of 90.2 square miles and ranges in elevation from 285 feet above sea level to 5,933 feet at the summit of Pitcher Mountain. The basin climate consists of warm, dry summers and cool, wet winters. Storms, which generally arrive from the west or southwest, are typically large frontal storms of low to moderate intensity and long duration precipitation.

The watershed upstream of the USGS stream gage South Prairie Creek at South Prairie, (station number 12095000) which contains 79.5 square miles, was used for the watershed and land-use analysis portion of the investigation. The lower floodplain area of South Prairie Creek extending from the Town of South Prairie to the mouth was used for the flood inundation part of the investigation (fig. 2).

The subsurface geology consists primarily of sedimentary and volcanic rock from the Eocene (the Puget Group, which includes the Spiketon, Northcraft, and Carbonado Formations), the Oligocene (Ohanapecosh Formation) and the Miocene (volcanic mudflow deposits) (Gard, 1968). The surface geology consists mostly of unconsolidated Pleistocene glacial-drift deposits known as the Vashon Drift (Crandell, 1963), with small areas of mudflow deposits. The drift consists primarily of glacial till deposited at the base of the glacier ice and stratified drift deposited by glacial meltwater. The till is well compacted and allows little infiltration of water, and the stratified drift is much less compacted and is found throughout the basin. About 4,800 years ago after volcanic eruptions on Mt. Rainier, the Osceola mudflow flowed down the White River, and a sizable lobe flowed down the South Prairie Creek valley. Much of the mudflow material remains exposed on the surface of the lower valley, and the remainder has been eroded and replaced with recently deposited gravel and cobble alluvium in the stream channel and silt and sand in the adjacent flood plain (Crandell, 1963).

The land cover in the upper basin is mostly forest, and timber harvesting by clear-cutting is common. Much of the land is under the management of the Mount Baker Snoqualmie National Forest (27.3 square miles). In the lower part of the basin, scattered dairy farms occupy a relatively broad floodplain, with pockets of residential development. Urbanization is gradually increasing, but the largest town in the basin, Wilkeson, has a population of only 370 , and second largest is the town of South Prairie, with a population of 180 (Office of Financial Management, 1991). 


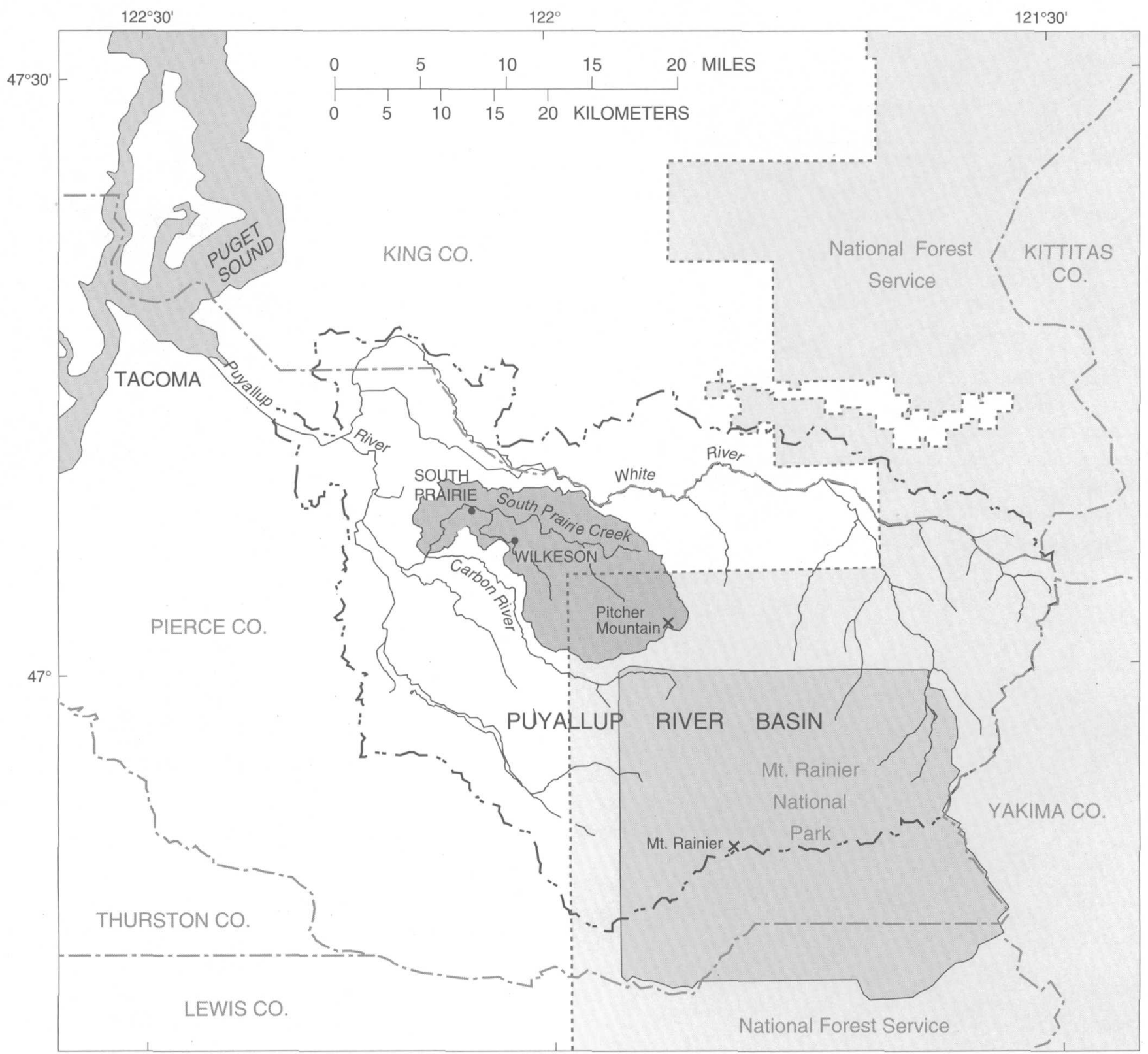

\section{EXPLANATION}
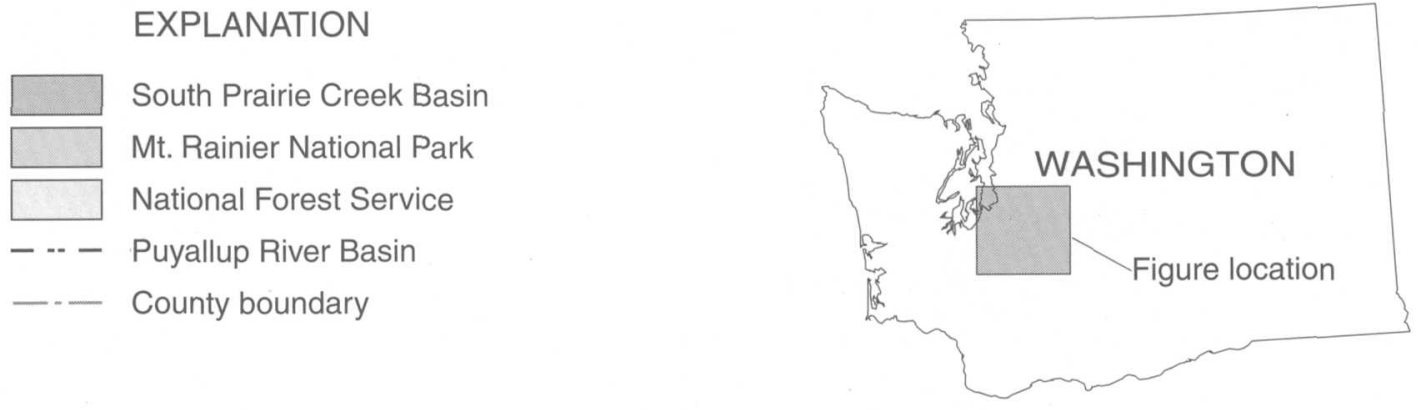

Figure 1. Study area showing South Prairie Creek and its basin boundaries and the Puyallup River system and its basin boundaries. 


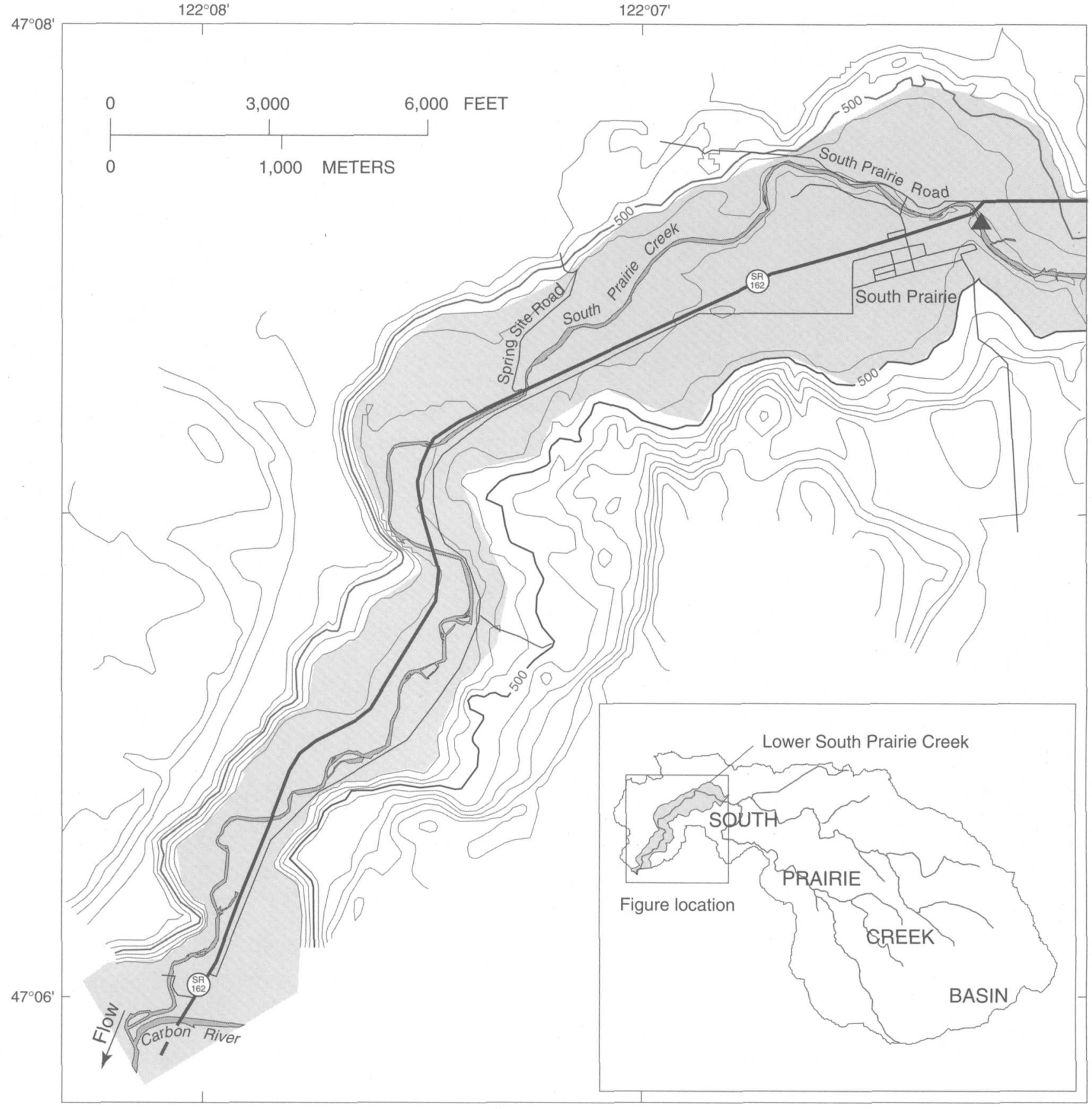

\section{EXPLANATION}

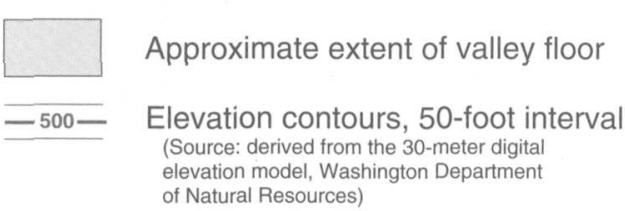

- Stream gaging station, USGS No. 12095000

Figure 2. Lower South Prairie Creek, showing the approximate extent of the valley floor, the stream gaging station, and the confluence with the Carbon River. 


\section{FLOOD HYDROLOGY}

This section briefly discusses the South Prairie Creek flood history and the most important characteristics related to flooding in the basin: precipitation distribution, precipitation-runoff relations, and land use, although there are little or no data to accurately quantify these characteristics. For example, there are no long-term precipitation stations in the basin, there are no snow gages in the basin, nor is there any comprehensive history of land use in the basin. In the South Prairie Creek Basin the precipitation-runoff process is further complicated by snow-accumulation and snowmelt processes that can vary significantly over time as the temperature changes or vary significantly over space from the headwaters to the lowland floodplain. The items discussed in this section provide some of the fundamental hydrologic information that will help to explain the approach used for the construction of the watershed model and the framework for statistical analyses discussed later in this report.

\section{Flood History}

The recent flood history of South Prairie Creek is chronicled by the records of annual peak discharges (table 1) at the USGS-operated stream gaging station, South Prairie Creek at South Prairie, Wash. The gage was operated from water year 1950 to 1979 and from 1988 to the present (1996), providing 39 years of annual peak discharge data. Records of continuous streamflow were collected during these periods except for water years 1972 to 1979 , when only a crest-stage gage (to determine peak discharges) was operated at the same location.

All the annual peak discharges occurred during the months of October through March. Most occurred during December and January (62 percent), only one occurred in October, and only two occurred in March.

Floods in the 1990 and 1996 water years (the fourth largest and largest annual peak discharges in the 1950 to 1979 and 1988 to 1996 periods) washed out an existing levee at Spring Site Road, flooded Highway 162 at several locations, and flooded many homes in the floodplain (fig. 2). The second largest peak discharge of record, which occurred in December 1955, washed out a highway bridge located 0.3 miles downstream of its present location (Bridge 5, fig. 23) (Federal Emergency Management Agency, 1981.p. 4).

\section{Precipitation Distribution}

Flood runoff, which is related to the amount of precipitation the basin receives during a storm, can vary dramatically at different locations in the South Prairie Creek Basin. Therefore, an understanding of the precipitation distribution in the South Prairie Creek Basin is needed to understand flooding and construct an accurate simulation model. This section illustrates the precipitation distribution and shows how a map of the mean annual precipitation in conjunction with a digital elevation model of the South Prairie Creek Basin can explain much of the variation that is due to elevation differences.

The distribution of precipitation over the basin and surrounding area is shown by the lines of equal mean annual precipitation on figure 3 , which is a section of a map produced for the entire state of Washington (Soil Conservation Service, 1965). The mean annual precipitation over the South Prairie Creek Basin varies from approximately 44 inches near the mouth to 85 inches near the headwaters. The distribution matches closely with the change in elevation-as elevation increases, precipitation increases. However, the relation of increased precipitation with increased elevation is sometimes disrupted by the local topography, especially with north-south trending ridges that provide a rain shadow effect (areas on the leeward side of a mountain or ridge receive less precipitation than they would with no mountain or ridge) to stations east of the ridges. For example, the Buck Creek gage, which is 900 feet higher than the nearby Greenwater gage and lies east of Huckleberry Ridge in its rain shadow, receives approximately 8 inches less precipitation per year than the Greenwater gage.

The precipitation-elevation relation for South Prairie Creek Basin was determined for the purposes of illustration and for construction of the watershed model. Using Geographical Information System (GIS) techniques, lines of equal mean annual precipitation (fig. 3) were used along with a digital elevation model of South Prairie Creek Basin to compute the average mean annual precipitation at the midpoints of eleven elevation zones (fig. 4).

The 5-day precipitation totals at the network of rain gages (fig. 3) for two flood-producing storms in the 1996 water year illustrate some of the variability of precipitation in the region. The storm in November 1995 resulted in a peak flow of 3,060 cubic feet per second $\left(\mathrm{ft}^{3} / \mathrm{s}\right)$, which overtopped the banks of South Prairie Creek at many locations in the lower floodplain. Winds during the storm 
were initially from the south until November 28 and 29 , when they came from the north (recorded at the Buck Creek Camp gage). The storm in February 1996 produced the largest recorded peak discharge on South Prairie Creek, with wind primarily from the south throughout the storm.

The 5-day precipitation totals (table 2) show that the precipitation varies considerably among stations at different elevations; however, the variation is reduced when the precipitation is expressed as percentages of mean annual precipitation. There are some notable discrepancies, however. The Electron station recorded significantly higher percentages than any other station in both storms, and percentages in all of the low-elevation stations were less than the high-elevation stations during the November storm.

\section{Precipitation-Runoff Relations}

The relation between precipitation and runoff is important to understanding flooding because the dominant type (or types) of runoff processes that occur determines the timing and magnitude of the peak flows. Snow accumulation and melt in the basin is often a key hydrologic process that determines whether or not a particular storm will produce a notably large flood.

Table 1. Annual peak discharge and relative rank for South Prairie Creek at South Prairie, Washington, for water years 1950 through 1996

$\left[\mathrm{ft}^{3} / \mathrm{s}\right.$, cubic feet per second $]$

\begin{tabular}{|c|c|c|c|c|c|c|c|}
\hline $\begin{array}{l}\text { Water } \\
\text { year }\end{array}$ & $\begin{array}{l}\text { Month/ } \\
\text { day }\end{array}$ & $\begin{array}{l}\text { Annual } \\
\text { peak } \\
\text { discharge } \\
\left(\mathrm{ft}^{3} / \mathrm{s}\right)\end{array}$ & Rank & $\begin{array}{l}\text { Water } \\
\text { year }\end{array}$ & $\begin{array}{l}\text { Month/ } \\
\text { day }\end{array}$ & $\begin{array}{l}\text { Annual } \\
\text { peak } \\
\text { discharge } \\
\left(\mathrm{ft}^{3} / \mathrm{s}\right)\end{array}$ & Rank \\
\hline 1950 & Dec./ 28 & 2,930 & 20 & 1970 & Jan./ 20 & 1,890 & 31 \\
\hline 1951 & Feb./ 11 & 3,550 & 13 & 1971 & Jan./ 19 & 2,710 & 25 \\
\hline 1952 & Feb./. 4 & 1,460 & 36 & 1972 & Mar./ 5 & 3,410 & 15 \\
\hline 1953 & Jan./ 31 & 2,660 & 26 & 1973 & Dec./ 21 & 2,350 & 29 . \\
\hline 1954 & Dec./ 9 & 5,470 & 5 & 1974 & Jan./ 16 & 4,310 & 9 \\
\hline 1955 & Feb./ 8 & 3,440 & 14 & 1975 & Jan./ 18 & 5,020 & 7 \\
\hline 1956 & Dec./ 11 & 6,850 & 2 & 1976 & Dec./ 2 & 4,380 & 8 \\
\hline 1957 & Dec./ 9 & 2,750 & 24 & 1977 & Jan./ 18 & 710 & 39 \\
\hline 1958 & Jan./ 17 & 1,710 & 33 & 1978 & Dec./ 2 & 3,700 & 12 \\
\hline 1959 & Nov./ 12 & 3,160 & 18 & 1979 & Feb./ 6 & 2,770 & 23 \\
\hline 1960 & Nov./ 20 & 3,900 & 10 & 1988 & Dec./ 9 & 2,190 & 30 \\
\hline 1961. & Nov./ 24 & 3,340 & 17 & 1989 & Oct./ 16 & 2,440 & 28 \\
\hline 1962 & Dec./ 24 & 1,760 & 32 & 1990 & Jan./ 9 & 5,930 & 4 \\
\hline 1963 & Feb./ 3 & 3,850 & 11 & 1991 & Feb./ 19 & 5,390 & 6 \\
\hline 1964 & Jan./ 25 & 3,380 & 16 & 1992 & Nov./25 & 1,700 & 34 \\
\hline 1965 & Jan./ 29 & 6,400 & 3 & 1993 & Jan./ 25 & 2,630 & 27 \\
\hline 1966 & Jan./ 6 & 985 & 38 & 1994 & Mar./ 3 & 1,500 & 35 \\
\hline 1967 & Jan./ 28 & 1,390 & 37 & 1995 & Feb./ 19 & 2,800 & 22 \\
\hline 1968 & Dec./ 25 & 2,840 & 21 & 1996 & Feb./ 8 & 8,200 & 1 \\
\hline 1969 & Jan./ 7 & 3,060 & 19 & & & & \\
\hline
\end{tabular}



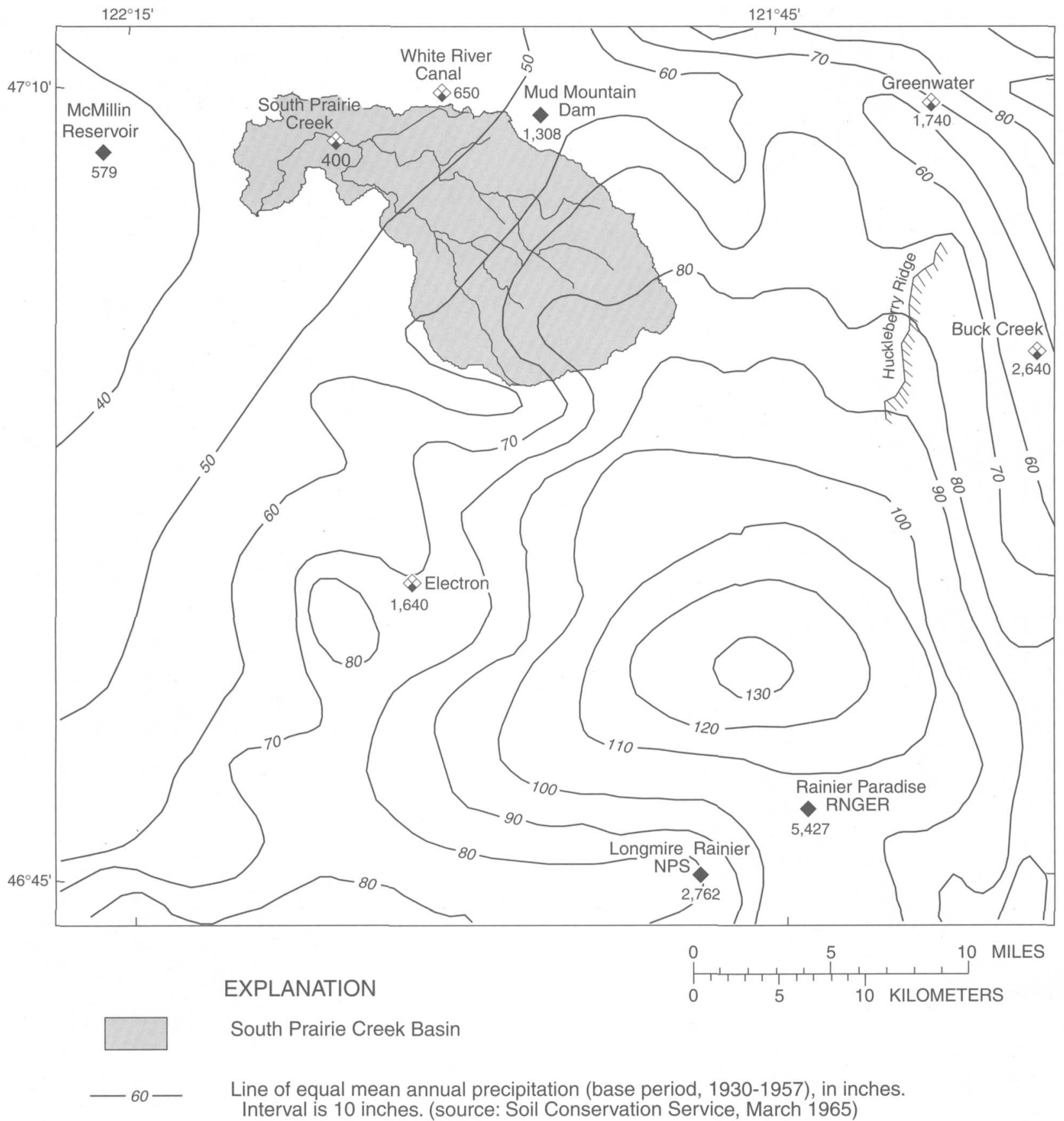

South Prairie

Creek USGS-operated precipitation gage, name, and elevation, in feet

McMillin Reservoir National Weather Service climate station location, name, and elevation, in feet 579

Figure 3. South Prairie Creek Basin, nearby weather stations, and mean annual precipitation. 


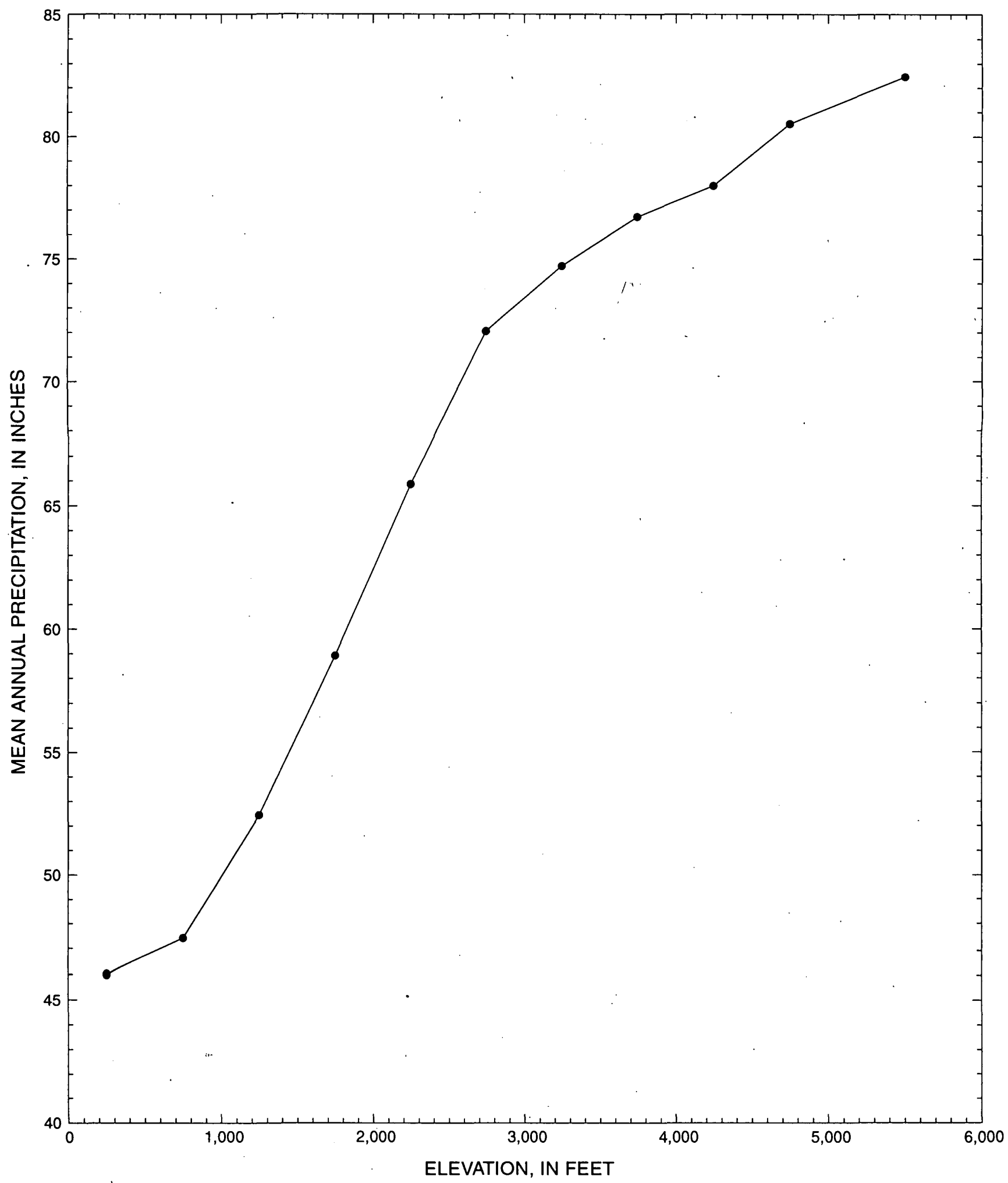

Figure 4. Mean annual precipitation as a function of elevation in South Prairie Creek Basin, Washington. 
Table 2. Five-day precipitation totals and the percent of mean annual precipitation for two storms for several nearby U.S. Geological Survey and National Weather Service stations

[Precip., precipitation; (USGS), U.S. Geological Survey operated; (NWS), National Weather Service operated; >, greater than]

\begin{tabular}{|c|c|c|c|c|c|c|}
\hline \multirow[b]{2}{*}{$\begin{array}{l}\text { Precipitation } \\
\text { station }\end{array}$} & \multirow[b]{2}{*}{$\begin{array}{l}\text { Elevation } \\
\text { (in feet) }\end{array}$} & \multirow[b]{2}{*}{$\begin{array}{l}\text { Estimated } \\
\text { mean annual } \\
\text { precipitation } \\
\text { (from fig. 3) } \\
\text { (inches) }\end{array}$} & \multicolumn{2}{|c|}{ November 25-29, 1995} & \multicolumn{2}{|c|}{ February 4-8, 1996} \\
\hline & & & $\begin{array}{l}\text { 5-day } \\
\text { precip. } \\
\text { total } \\
\text { (inches) }\end{array}$ & $\begin{array}{l}\text { Percent } \\
\text { of mean } \\
\text { annual } \\
\text { precip. }\end{array}$ & $\begin{array}{l}\text { 5-day } \\
\text { precip. } \\
\text { total } \\
\text { (inches) }\end{array}$ & $\begin{array}{l}\text { Percent } \\
\text { of mean } \\
\text { annual } \\
\text { precip. }\end{array}$ \\
\hline $\begin{array}{l}\text { South Prairie Creek at South } \\
\text { Prairie (USGS) }\end{array}$ & 400 & 47 & 3.69 & 7.9 & 7.02 & 14.9 \\
\hline McMillin Reservoir (NWS) & 579 & 39 & 2.85 & 7.3 & 5.20 & 13.3 \\
\hline $\begin{array}{l}\text { White River Canal at } \\
\text { Buckley (USGS) }\end{array}$ & 650 & 48 & 3.43 & 7.1 & 5.69 & 11.9 \\
\hline Mud Mountain Dam (NWS) & 1,308 & 54 & 4.60 & 8.5 & 7.30 & 13.5 \\
\hline $\begin{array}{l}\text { Puyallup River at } \\
\text { Electron (USGS) }\end{array}$ & 1,640 & 72 & 11.00 & 15.3 & $>13.56^{*}$ & $>18.8$ \\
\hline $\begin{array}{l}\text { Greenwater River at } \\
\text { Greenwater (USGS) }\end{array}$ & 1,740 & 66 & 8.12 & 12.3 & 8.84 & 13.4 \\
\hline $\begin{array}{l}\text { Buck Creek Camp near } \\
\text { Greenwater (USGS) }\end{array}$ & 2,640 & 58 & 5.94 & 10.2 & 7.87 & 13.6 \\
\hline Longmire Rainier NPS (NWS) & 2,762 & 80 & 10.75 & 13.4 & 9.09 & 11.4 \\
\hline Rainier Paradise RNGER (NWS) & 5,427 & 106 & 13.83 & 13.0 & 10.96 & 10.3 \\
\hline
\end{tabular}

*Missing 13 hours of data on February 8, 1996, when the flood destroyed the gage.

\section{Runoff Processes}

In basins with a humid climate and permeable soils, such as the South Prairie Creek Basin, storm runoff, as conceptualized by Hewlett and Hibbert (1967) with the variable-source concept, most likely results from a combination of Horton and saturation overland flow and subsurface flow. In the variable-source concept, areas of runoff production (source areas) within a basin will vary in size seasonally and during storms. Also, storms of similar rainfall totals may produce floods of varying sizes depending on the basin soil properties, antecedent moisture conditions, and the intensity and duration of the rainfall.
Horton overland flow occurs when the rainfall intensity is greater than the infiltration capacity of the soil (Dunne and Leopold, 1978, p. 259). In South Prairie Creek Basin, the rainfall intensities are relatively low. The average rate of rainfall over a 6-hour period exceeded on average only once in every 100 years varies from approximately 2.2 to 3.2 inches (U.S. Department of Commerce, 1973). These rates are well below the infiltration rates of 10 to 50 inches per hour for undisturbed forest soils of the Puget Lowlands (Burges and others, 1989), and Horton overland flow will rarely occur on these soils. On bare rock, pavement, or compacted ground, however, Horton overland flow can be the dominant runoff process. 
Saturated overland flow occurs when the soils become saturated and any further additions of water become overland flow (Dunne and Leopold, 1978, p. 265). It occurs most often in valley bottoms and depressions where a local water table is near the surface and in relatively flat-lying areas after a period of rainfall has saturated the soil. In Western Washington, the rainy season generally begins in October, but in order to generate significant runoff, the soil-moisture, depleted after a dry summer, must be replenished first. Figure 5 illustrates this seasonal lag between the onset of the rainy season and the flood season. The two storms on figure 5 have similar precipitation totals and intensities, similar lag-to-peak times, and similar above-freezing temperatures. (No snowfall was recorded at the Rainier Longmire National Weather Service (NWS) weather station during either storm.) The December storm had 18 percent less precipitation than the October storm, but the peak discharge was 2.5 times larger. Much of the rainfall in the October storm infiltrated the ground and was stored in the soil while in December, after two more months of rain had saturated the soil, most of the rainfall probably became overland flow.

\section{Snow Accumulation and Melt}

The heart of the South Prairie Creek Basin lies in a transient snow zone (a zone of transition between a low altitude zone where most of the precipitation is rain and a high-altitude zone where most of the precipitation is snow), and therefore rain-on-snow storms may contribute significantly to runoff. Harr (1986) defines the transient snow zone in western Oregon to be between about 350 and 1,100 meters (1,150 and 3,600 feet). For the South Prairie Creek Basin, this represents about 65 percent of the drainage area.

When precipitation falls as snow, there is little or no immediate contribution to runoff. However, if the snow melts during a rainstorm, it may significantly augment the runoff from the storm. Large differences in peak discharges often can be attributed to the contribution of snowmelt. The 1961 water year peak discharge, for example, was substantially augmented by snowmelt, as indicated by the 3-day snowmelt index (table 3). Three days prior to the 1961 water year peak, the Longmire Rainier National Park Service (NPS) station reported 13 inches of snow on the ground, 1.5 inches fell in the next 3 days, and 7 inches was on the ground on the day of the peak. Three days prior to the 1992 water year peak, the same station reported no snow on the ground. Even with a half inch more rain, the 1992 water year peak was only about half the 1961 water year peak.
The snowmelt index used in table 3 is a simple indicator of snowmelt contribution to characterize a flood peak by the contribution of water from snow. A more meaningful indicator would be the basin-wide contribution in inches of equivalent water or snow-water equivalent (SWE). The amount of snow on the ground in this zone at any given time during the flood season varies considerably, ranging from zero to several feet. A continuous areal accounting of snow accumulation and melt must be made to determine basin-wide contributions of snowmelt to runoff. Surface air temperature, which is strongly related to elevation and is the single most reliable index to snowmelt (Linsley and others, 1982, p.253), was used in a watershed model in a later section of this report to estimate snowmelt contributions to runoff for all observed annual peaks.

\section{Previous Investigations of the Effects of Logging on Flooding}

The effects of logging, primarily clear-cutting and road building, are generally believed to increase flooding; however, depending on the type of logging used, the percentage of the basin affected, or the size of the floods being analyzed, many studies conclude that there are no significant increases in flooding after logging has occurred. Road building is generally closely associated with logging, and because the South Prairie Creek Basin lies in the transient snow zone where snowmelt can often augment rainfall and significantly increase flood peaks, the effects of clear-cuts and road building are discussed with a review of some of the literature for cases in the Pacific Northwest.

Logging and road building compact soils and thus reduce infiltration capacity and increase surface runoff and peak flows (Wright and others, 1990). Roads also intercept and convert subsurface flows to surface flows, thereby increasing peak flows (Jones and Grant, 1996). Harr and others (1975) found significant increases in peak flows after road building, but only when the roads occupied at least 12 percent of the watershed. Wright and others (1990, p. 1657) found that in northwest California "storm volumes and peaks of large storms... were not significantly increased by either roads or logging even though more than 15 percent of the watershed was compacted in roads, skid trails and landings." Jones and Grant (1996, p. 970) found that road building in combination with clear-cutting in western Oregon resulted in "significant increases in all sizes of peak discharges in all seasons." 

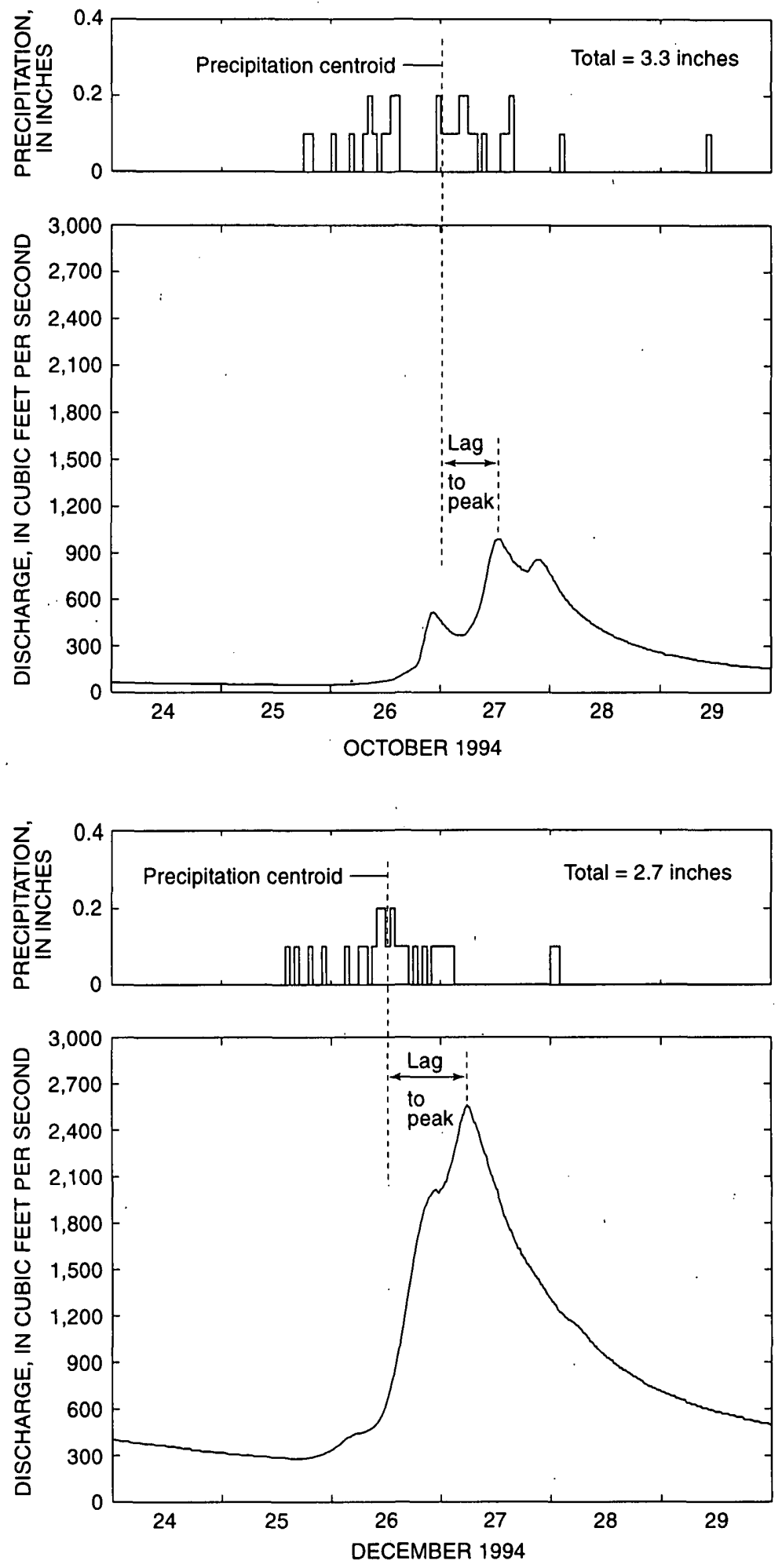

Figure 5. Discharge at South Prairie Creek (station number 12095000) and precipitation at Mud Mountain Dam for two storms in 1994. 
Table 3. Two annual peak discharges, 3-day basin precipitation, and 3-day snow-melt index contrasting the influence of snowmelt on peak discharges in South Prairie Creek Basin, Washington

\begin{tabular}{llllc}
\hline $\begin{array}{l}\text { Water } \\
\text { year }\end{array}$ & $\begin{array}{l}\text { Peak date } \\
\text { month/day }\end{array}$ & $\begin{array}{l}\text { Peak } \\
\text { discharge } \\
\text { (cubic feet } \\
\text { per second) }\end{array}$ & $\begin{array}{l}\text { 3-day }{ }^{1} \text { basin } \\
\text { precipitation } \\
\text { (inches) }\end{array}$ & $\begin{array}{l}\text { 3-day snow-melt } \\
\text { index for Longmire } \\
\text { Rainier National } \\
\text { Park Service Station }\end{array}$ \\
\hline 1961 & Nov/24 & 3,340 & 2.12 & 7.5 \\
1992 & Nov/25 & 1,700 & 2.60 & 1 \\
\hline
\end{tabular}

${ }^{1}$ 3-day period begins at midnight 3 days before the peak date and ends at midnight the day of the peak.

23-day basin precipitation is the total of the weighted 3-day precipitation totals at three National Weather Service precipitation stations representing three elevation zones; McMillin Reservoir (400-1,000 feet); Mud Mountain Reservoir (1,000-3,400 feet), and Rainier Paradise Ranger Station (3,400-5,800 feet). The station weights are computed by the following equation:

$$
\text { Station weight }=\left(\frac{\text { Area }_{\text {Elevation Zone }}}{\text { Area } \text { South Prairie Creek Basin }_{\text {S }}}\right) \times\left(\frac{N A P_{\text {Elevation Zone. }}}{N A P_{\text {Station }}}\right),
$$

where NAP is the Normal Annual Precipitation (1930-57).

3-day snow-melt index, $\mathrm{Sm}$ is computed as follows:

$$
S m=S t_{3 \text { days before peak }}-S t_{\text {peak date }}+S f_{3-\text { day total }},
$$

where $S t$ is the observed snow on ground in inches and $S f$ is the observed snowfall in inches (National Oceanic and Atmospheric Administration, 1961 and 1992).

Harr (1981) and van Heeswijk and others (1996) hypothesized that for the transient-snow zone in the Pacific Northwest, snowmelt and water available for runoff (WAR) would be greater in clear-cut areas than in forests. Berris and Harr (1987) showed that snow accumulation increases when the forest canopy is removed and during rain events snowmelt is greater in clearings than in the forest due to increased amounts of sensible and latent heat from increased wind (Berris and Harr, 1987). Rothacher (1970) found no "noticeable" change in the largest peak flows following a clear-cut in two experimental watersheds in the transient snow zone in western Oregon, but he ignored the changes in the smaller, more moderate floods. However, Harr (1986) argued that the increases in moderate-sized floods after logging is important to consider because of their potential for moving sediment and altering the channel. He concluded, after updating and reanalyzing the data for the same experimental watersheds, that clear-cut logging has altered snow accumulation and melt and increased the moderate peak flows with return periods of 3-8 years. Berris and Harr (1987), in the same experimental forest, determined that the runoff per unit area during a rain-on-snow storm was 21 percent greater from the clear-cut plot than from the nearby forest plot. Rosencrantz and others (1996) found an increasing trend in the annual peak discharge since 1961 in the Snoqualmie River Watershed (approximately 30 miles north of South Prairie Creek), where the area of clearings has generally been increasing.

Many studies have shown that clear-cutting and road building can increase both the amount of erosion from the land and sedimentation in streams (see Brown, 1983 for a review and discussion) and, thereby, indirectly contribute to flooding. Increased sedimentation in a channel will reduce its flood-carrying capacity. Floods that normally would be contained in the channel prior to the build-up of sediments may overtop the banks and cause flooding as its flood-carrying capacity decreases. Increases in sedimentation rates after logging vary with the practice used for harvesting and road building. In a study during which tree debris was left on the ground, Likens and others (1970) found no increases in sedimentation rates after clear-cutting. On the other end of the scale, road building, especially road-caused mass failures, can produce huge increases in sediment production. Fredriksen (1970) found sediment yields during the first storms after road building in an Oregon watershed to be 250 times the sediment yield of a nearby undisturbed watershed. 


\section{HISTORY OF LAND USE IN THE BASIN}

Some residents of the town of South Prairie suggest that timber harvesting (the primary land use in the basin) in the upper watershed has increased the amount of flooding in the lower floodplain. As a first step to evaluate the reasonableness of the claim, it was decided that a summary of the recent history of timber harvesting in the basin was necessary to gain some insight on the changes occurring in the basin. Attempts to obtain records of land use in the basin were fruitless because of the mixed land ownership and mixed methods of classifying lands. Therefore, as a part of this investigation, areas of selected land uses at five points in time from 1965 to 1990 were delineated on four sets of black and white aerial photographs of the basin $(1965,1971,1976$, and 1983) and on one set of orthophoto maps for 1990 . These coverages span the period of complete air photo coverage of the basin available from the State of Washington Department of Natural Resources (1965 to 1990).

Areas of clear-cuts, pastures, and residential areas and roads were delineated on the four complete sets of aerial photos and the one set of orthophoto quads obtained from the Washington State Department of Natural Resources. The combined areas of pastures and residential areas (mostly rural, low-density housing) account for only 2.9 to 4.0 percent of the total area, they did not vary much from year to year, and they were difficult to delineate. For these reasons, these two categories were lumped together with the clear-cuts into one group called clearings in this analysis. Areas delineated as clearings included all areas that had not been overgrown with brush and young trees.

Recent clear-cuts are distinctly visible on the aerial photos due to the contrast between the bare ground and the surrounding forest. As several years pass, the clear-cut area begins to revegetate, and brush and small trees cover most of the bare ground. The boundaries of the clear-cuts, however, are still visible on the aerial photos due to the contrasting textures and shades of gray. Once a nearcontinuous cover of brush or small trees occupies a former clear-cut, the designation changes to forest. The same visual criteria for these designations were used consistently throughout the five coverages, and therefore the relative change between coverages should be accurate. Trails or driveways were not designated as roads nor was any distinction made for the type of road surface.

After the delineations were made, the aerial photos were corrected planimetrically on a stereo plotter to eliminate horizontal distortion. Horizontal coordinates determined from 7.5-minute USGS quadrangle maps for locations visible on the photos were used in the photo-cor- rection process. The coordinates generated by the stereo plotter of the land-use polygons and arcs representing roads were transferred to a Geographical Information System (GIS) and clipped to a common outline of the basin. Total acreages of clearings and mileages of roads were computed for each GIS coverage. Land-use delineations were digitized directly off the orthophotos because they are already corrected for horizontal distortion.

From 1965 to 1990, the total acreage of clearings and mileage of roads in South Prairie Creek Basin increased dramatically (fig. 6 and 7). Clearings represented 11.2 percent of the total area (total drainage area $=79.5 \mathrm{mi}^{2}$ or 50,880 acres) in 1965 , gradually increased to 15.0 percent by 1976 , began to increase more rapidly to 20.0 percent in 1983 , and then increased significantly to 34.5 percent by 1990 . Road mileage increased from 119.6 miles in 1965 to 237.0 miles in 1990.

With the level of road building and clear-cutting that South Prairie Creek has experienced, it can be expected that the erosion and sedimentation rates have increased over time since 1965. As a part of this study (see the section "Comparisons of channel cross sections"), floodplain and channel cross sections surveyed in 1976-77 and again in 1995-96 were compared to assess any changes in the flood-carrying capacity of the lower portion of South Prairie Creek.

\section{TRENDS IN FLOODING ON SOUTH PRAIRIE CREEK}

As described previously, flood hydrology involves the complex influences and interplay of weather and basin characteristics. Detecting a trend in flooding requires a change over time that is so persistent that it is clearly distinguished from random noise or short-lived patterns that are common in real climatic and hydrologic data. A number of mathematical or statistical techniques have evolved to detect such trends. In an attempt to detect any trend in flooding on South Prairie Creek that might be due to land-use changes, several statistical analyses, each of increasing power and complexity, were applied to the flood data. These analyses range from relatively simple comparisons of the number and magnitude of flood peaks to rather complex analysis involving exogenous variables that act to remove or screen out some of the climatic noises in the data and thereby increase the ability of the analysis to detect a trend. 

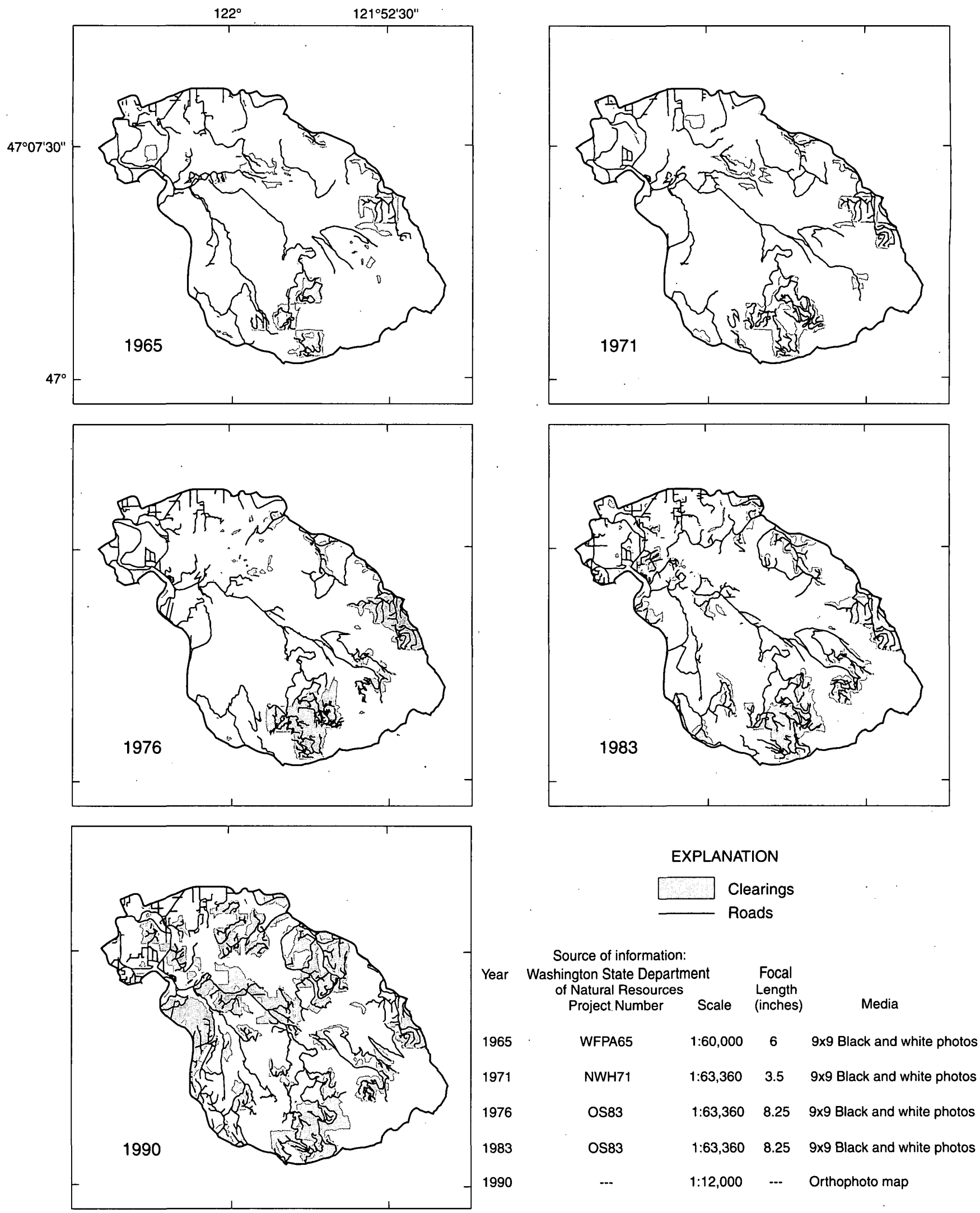

Figure 6. Clearings and roads determined from aerial photo interpretation, South Prairie Creek Basin, Washington. 


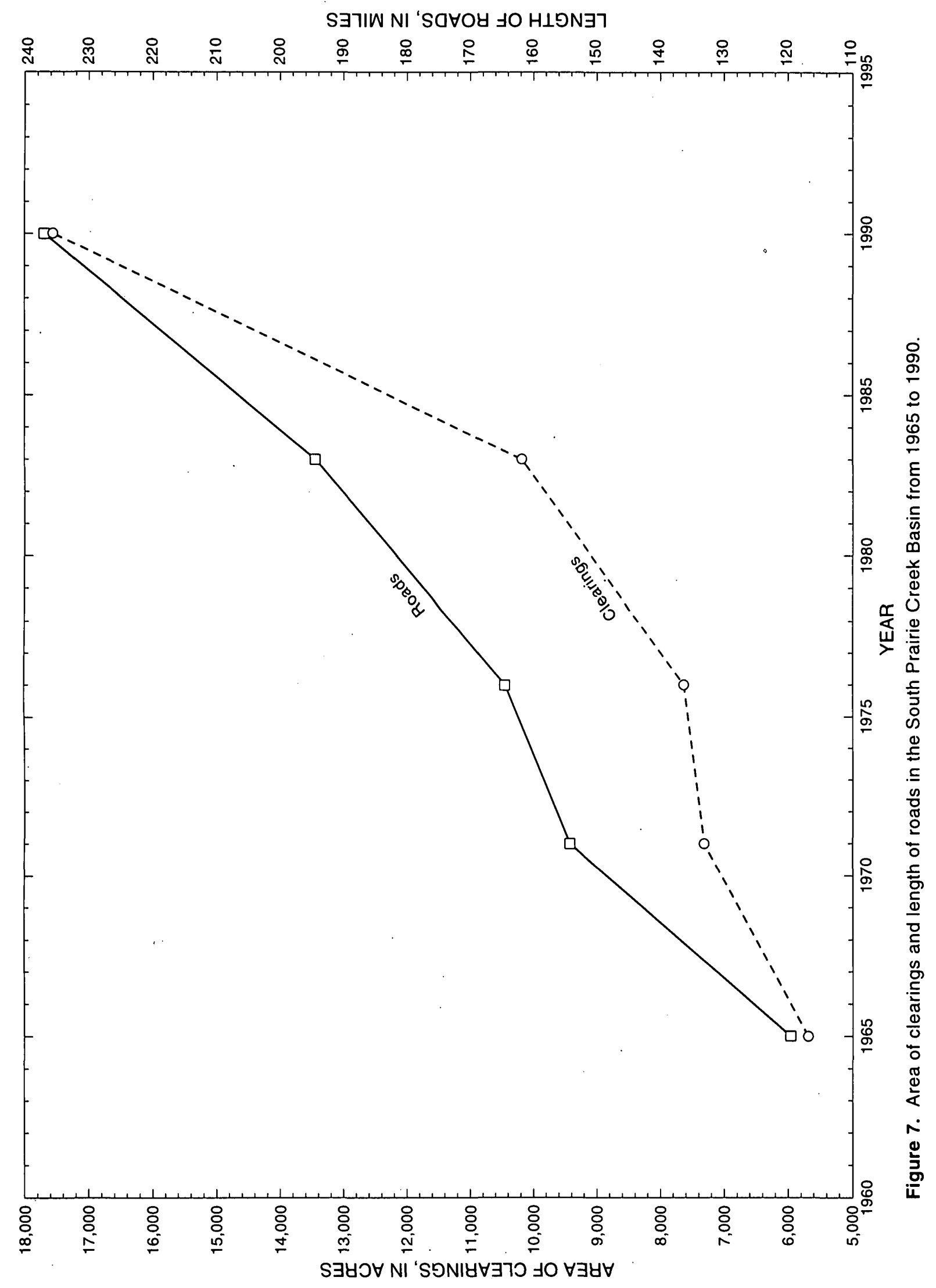


For this analysis, three tests for trends were performed: a test for increasing flood frequency applied to the annual number of peak discharges above a base discharge; a test for increasing flow magnitude applied to the annual peak flows; and another test for increasing flood magnitude applied to the annual peak flows after adjustment for variable climatic conditions. All three tests produced the same result: no statistically significant trend was evident.

\section{Frequency of Flooding-Pre-logged Versus Post-logged}

An examination of the annual number of observed peak discharges above a base discharge can be used to detect a change in the frequency of flooding on a stream. The USGS has an established base discharge of $1,400 \mathrm{ft}^{3} / \mathrm{s}$ for the South Prairie Creek gage and has a data base of all the peak discharges above the base discharge for water years 1950-71 and 1988-96. The data collected for this gage site during 1972-79, when it was operated as a crest-stage gage, was not used in this analysis because it contains only the annual peak discharge for each year of record. The period 1950-71, when only a low percentage of the watershed was cleared, was defined in this analysis as "pre-logged," while the period 1988-96, when a much higher percentage of the watershed had been cleared, was defined as "post-logged."

A visual examination of the data is inconclusive. Figure 8 shows the frequency of peaks for the two periods with mean and median values. Although the mean number of peaks per year is higher in the post-logging period, the medians are the same. Figure 9 shows how the numbers are distributed. The post-logging period has two water years with the highest number of peaks, but it also has three years - one third of the total-with only one peak above the base. The number of peaks per year above the base during the pre-logging period is more evenly distributed at the lower frequencies.

The means of the number of peak discharges above a base discharge per year and the sum of their ranks were analyzed to determine if there was significant difference in flooding between the two periods. Although the data indicate that the mean increased from 2.5 peaks above base per year to 3.3 peaks above base per year, a statistical comparison of the means using the t-test was inconclusive.
A separate-variance t-test was used because of the unequal size of samples and amount of variance (after Ott, 1993), and the difference was not statistically significant at the 5-percent level. Analysis of the data using the Wilcoxon Rank-Sum test produced the same result. There was no statistical difference at the 5-percent level.

\section{Trends in the Annual Peak Discharges}

The question of whether the flood potential of South Prairie Creek has changed in recent history can be addressed with an analysis of observed annual peak discharges. As shown in the next section, a simple plot of annual peak discharges over time shows a large scatter of values and provides little evidence whether the potential for flooding is increasing. A large effort was made to develop an appropriate exogenous variable. In the end, peak discharges simulated by a physically based numerical model provided the best exogenous variable to explain the background variation due to weather variation. The method of using simulated discharges from a watershed model as an exogenous variable is described by Helsel and Hirsch (1995, p. 332). After a suitable exogenous variable was developed, several statistical tests were performed to search for a trend in the data.

\section{Annual Peak Discharge Over Time Without Correction for Weather Variability}

A plot of the annual peak discharges against time (fig. 10) shows a large, random scatter of values with no visually obvious trend. The Mann-Kendall nonparametric statistical test for trends, a test for determining whether values generally increase or decrease with time, also detected no trend in the data. In this test, Kendall's tau correlation coefficient was -0.012 , indicating little or no trend (tau = 1 for a perfectly positive trend; that is, all peak discharges increase with time, and tau $=-1$ for a perfectly negative trend; that is, all peak discharges decrease with time). Kendall's test statistic, $S$, had a p-value of 0.921 , strongly indicating that there is not enough evidence to refute the null hypothesis that there is no trend of increasing or decreasing peak discharges with time. 


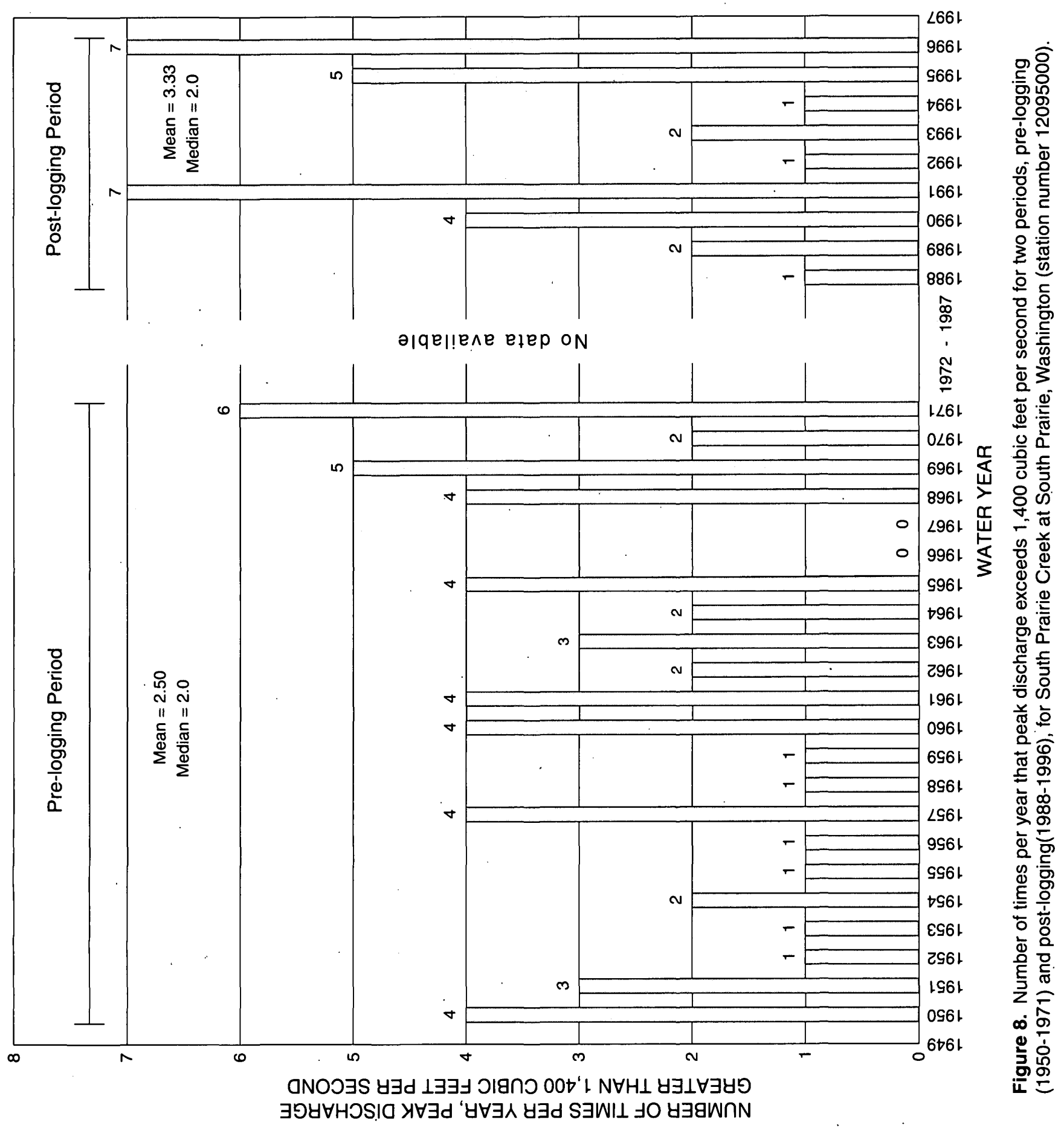




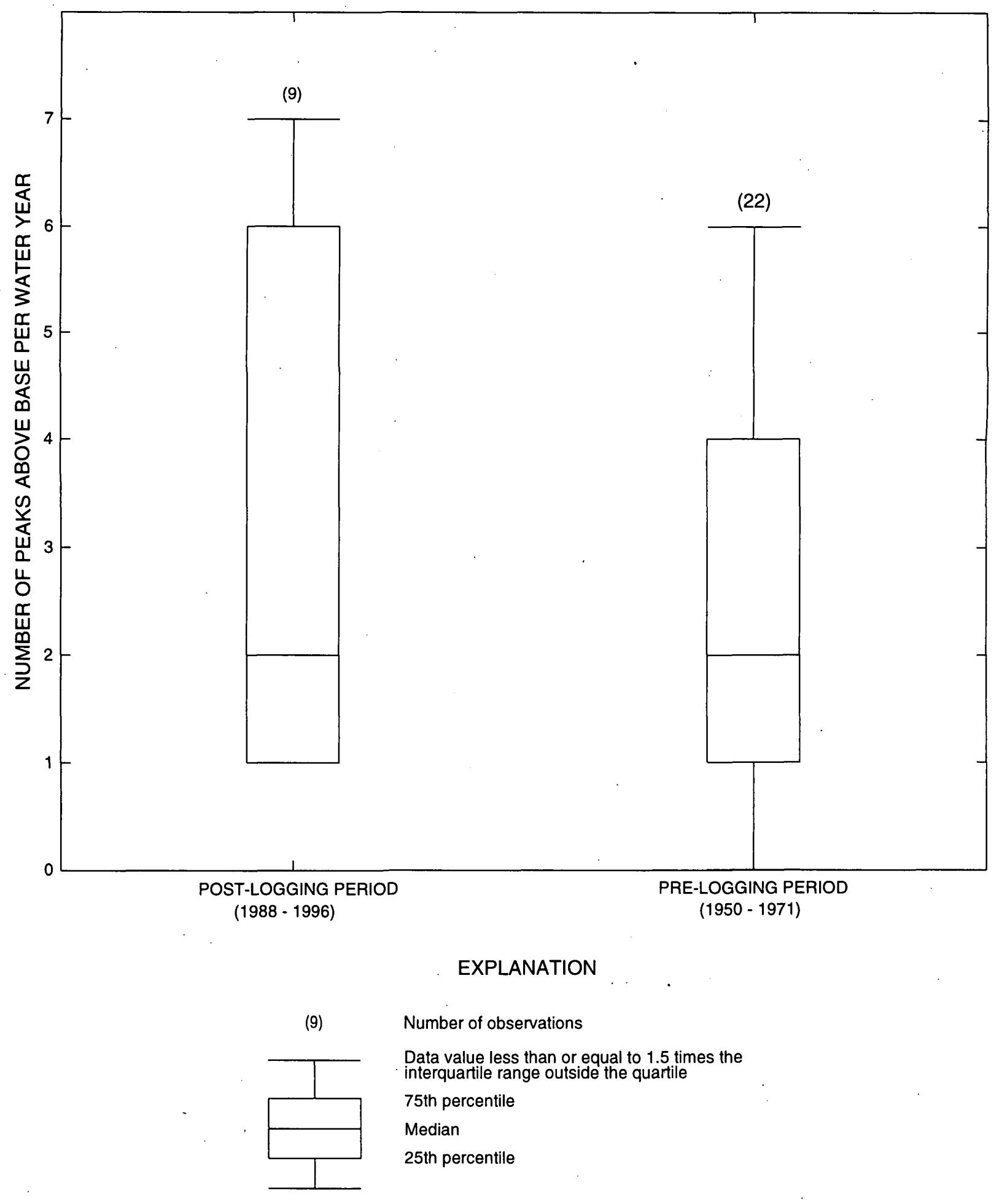

Figure 9. Distribution of the number of peaks above base discharge per water year for the post-logging and pre-logging periods for South Prairie Creek at South Prairie, Washington. 


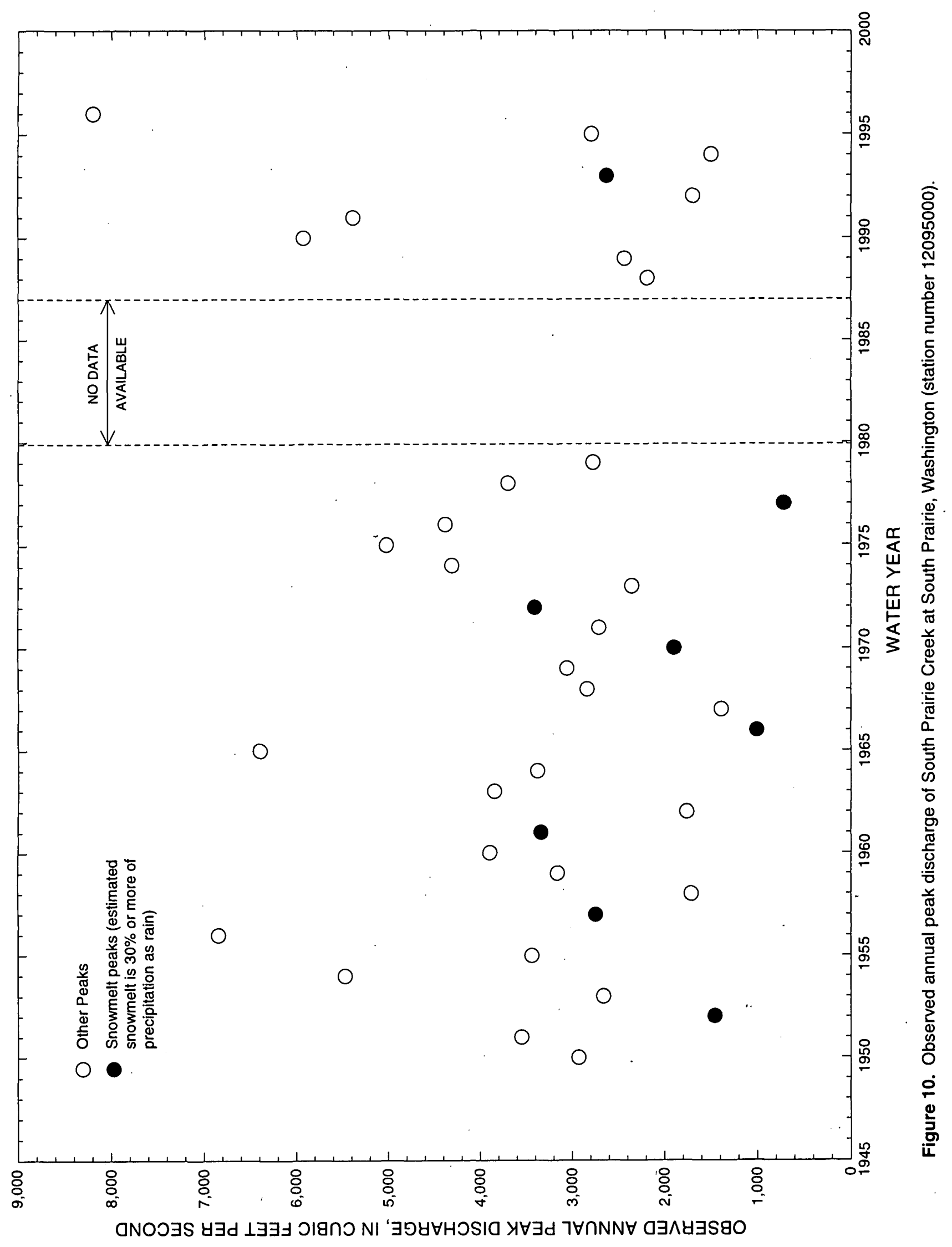




\section{Development of an Exogenous Variable}

The large scatter of peak discharge values over time (fig. 10) is due to the natural variability of weather and soil moisture that influences peak discharges. It is common to have storms in one year that are much more intense than in another year, resulting in a larger peak flow. Weather variability produces "background noise" that may hide trends that may be due to changes in the basin. In order to remove the noise (the effect of weather) and increase the power of the statistical test for trend, an exogenous variable is used to remove or reduce the effects of weather on the data. If there were an unlogged, undeveloped gaged basin nearby in the same climate zone as South Prairie Creek Basin, its peak-flow data could be used as an exogenous variable-unfortunately, no such basin exists.

Knowledge of the flooding processes in the South Prairie Creek Basin suggests that a useful exogenous variable would need to account for the varying amounts of precipitation, the type of precipitation-snow or rain, the amount of snow-melt contribution, and the antecedent soil moisture conditions.

For this study, several candidate variables were developed from daily observations of precipitation, temperature, and snow at nearby NWS stations to regress against the annual peak discharges. A simple relation of 1-, 3-, or 5-day precipitation totals, ending on the day of the annual peak discharge at a particular site to the peak discharge, resulted in low coefficients of determination $\left(R^{2}\right)$ and high standard errors of regression (table 4 ).
Further analysis with precipitation totals was made by weighting the totals according to the area in the basin that they represented and a ratio of the normal annual precipitation (NAP) of the representative area to the station's NAP. The peak discharges were regressed with the basinweighted, 3-day precipitation totals (3-day $\mathrm{P}_{\text {basin }}$ ); $\mathrm{R}^{2}$ was 0.433 , and the standard error of regression was 1271 .

Multiple regressions with 3-day $\mathrm{P}_{\text {basin }}$, a degree-day index (3-daydd ${ }_{\text {basin }}$ ), a snow index, and a snowmelt index were made. Minimizing the Mallow's Cp statistic (Helsel and Hirsch, 1995) was used to find the best model, and it resulted in a two-parameter model as the best model with the variables 3-day $P_{\text {basin }}$ and 3-daydd basin $\left(R^{2}=0.475\right.$, $\mathrm{R}^{2}$ adjusted $=0.446$, and Root MSE $=1,240$ ).

A properly designed and calibrated watershed model effectively takes into account the distribution, intensities, and type of precipitation, snowmelt, and antecedent soil-moisture conditions that control and vary storm runoff. The values of simulated peak discharges can be thought of as an index to WAR, reflecting the changing weather in the basin from year to year. Regressing the observed peak discharges against the simulated discharges should produce residuals from which the effects of the relevant meteorological variables have been removed. If the hypothesis that logging has increased peak flows over what they would be without logging is true, the trend should be evident in the normalized residuals.

Table 4. Results of linear regression of the annual peak discharges, in cubic feet per second, at South Prairie Creek (U.S Geological Survey station number 12095000) with the 5-, 3-, and 1-day precipitation totals for the indicated National Weather Service stations

$\left[\mathrm{R}^{2}\right.$ is the coefficient of determination; Root MSE is the standard error of the regression or square root of the mean square error, in cubic feet per second]

\begin{tabular}{|c|c|c|c|c|c|c|}
\hline \multirow{2}{*}{$\begin{array}{l}\text { National Weather Service } \\
\text { station name }\end{array}$} & \multicolumn{2}{|c|}{ 5-day totals } & \multicolumn{2}{|c|}{ 3-day totals } & \multicolumn{2}{|c|}{ 1-day totals } \\
\hline & $\mathrm{R}^{2}$ & RootMSE & $\mathrm{R}^{2}$ & RootMSE & $\mathrm{R}^{2}$ & RootMSE \\
\hline McMillin Reservoir & 0.215 & 1,496 & 0.291 & 1,421 & 0.283 & 1,429 \\
\hline Mud Mountain Reservoir & 0.381 & 1,328 & 0.374 & 1,335 & 0.351 & 1,359 \\
\hline Rainier Paradise RNGR & 0.012 & 1,717 & 0.239 & 1,506 & 0.144 & 1,598 \\
\hline
\end{tabular}




\section{Simulation of Annual Flood Peaks}

The Streamflow Synthesis and Reservoir Regulation (SSARR) watershed model, a model developed by the U.S. Army Corps of Engineers for managing the Columbia River, was constructed and calibrated for a real-time flood warning project on the Puyallup River. The South Prairie Creek portion of the SSARR watershed model (no channel routing of streamflows was made) for this study was extracted, and the drainage area of 79.5 square miles (at the South Prairie stream-gaging station) was used instead of 90.2 square miles (at confluence of Carbon River) as was used in the Puyallup River model. The SSARR user's manual (U.S. Army Corps of Engineers, 1991) has complete details of how the model works. The basin characteristics and runoff parameters used in the model are archived on the USGS Washington District computer in Tacoma, Wash..

The SSARR model is appropriate for simulating discharge peaks in South Prairie Creek because (1) it is a continuous model that accounts for antecedent soil-moisture conditions and snow accumulation, (2) it has a temperature-index snow-melt algorithm, (3) it divides the watershed into elevation zones (snowbands) and distributes precipitation (as rain or snow) and temperature according to defined precipitation-elevation curves and lapse rates (change in temperature with change in elevation), and (4) it distributes water available for runoff (WAR) into surface and subsurface flow paths as a function of soil moisture. The modeler defines the lag times for WAR to reach the stream for each of the flow components by routing each component with a simple storage-routing equation. The lag times define the shape of the simulated hydrograph, which is adjusted through the calibration process to mimic the shape of the observed hydrograph. Other important hydrologic processes simulated by the SSARR model include interception by vegetation, evapotranspiration, ripening of the snow pack, and ground melt of the snow pack. The hydrologic parameters that govern the simulation of the hydrologic processes are the same throughout the subbasin, although precipitation and temperature inputs are adjusted for each snowband by userdefined precipitation-elevation relations and temperature lapse rates.

The watershed was divided into the 11 elevation zones whose midpoint elevations are shown on figure 4. The relation between mean annual precipitation and elevation shown on figure 4 was used to compute one precipitation value for each model time step for each of the zones.
The model was run separately for each water year from 1950 to 1979 and 1988 to 1996 to simulate discharge at the South Prairie Creek stream-gaging site. Each run was started using a 6-hour time step, which was then reduced to a 1-hour time step 5 days before the annual peak. Input to the South Prairie Creek model consisted of hourly time series of observed precipitation at the NWS station at Mud Mountain Reservoir and two hourly time series of temperature, one at Mud Mountain Reservoir and one at another NWS station, Rainier Paradise Ranger Station (RNGR). The hourly temperature time series were estimated from observed minimum and maximum temperatures using methodology described by Ca'Zorzi and Dalla Fontana(1986). The Rainier Paradise RNGR temperature time series was used only to develop a time series of temperature lapse rates to be applied to the Mud Mountain Reservoir temperature data to compute a snowband temperature for the mid-point elevation of each snowband.

The errors inherent in the model's representation of the hydrologic processes are minimized through a trialand-error process of calibration-the adjustment of parameters to minimize differences between the observed and the simulated values - that generally represents a balance of the errors. The runoff parameters used in the South Prairie Creek model were originally taken from a slightly different version of the SSARR model used by the NWS River Forecast Center for real-time flood forecasting for the Carbon River Basin, which includes South Prairie Creek Basin (Charles Orwig, National Weather Service, written commun., 1993). Slight changes were made during the calibration process for the real-time flood warning model on the Puyallup River using the current network of USGS-operated precipitation stations (fig. 3), runoff data from water years 1994 through. 1996. Rather than recalibrating the runoff parameters for this investigation with the long-term NWS data, the model was used without further calibration. The snowmelt rate that was used during rain (the default value) is a calibrated rate for "heavily forested areas" (U.S. Army Corps of Engineers, 1956, p. 232).

Model parameters for runoff and meteorological inputs were held constant for the entire 39-year simulation period. The simulated peak discharge, basin-averaged rain, and snowmelt contributions to runoff were computed from the results (table 5). All of the simulated annual peak discharges except the one in the 1989 water year (an unusually early peak) were increased by snowmelt contributions that augmented the rain to increase peak discharge. About one quarter (10 of 39) of the peak discharges had snowmelt contributions that were at least 30 percent as much as the rain contributions. These 10 peak discharges are, herein, classified as snowmelt peaks. 
Table 5. Observed and simulated annual peak discharges and their difference, 3-day simulated basin-averaged rain, and 3-day simulated snowmelt totals for water years 1950 to 1979 and from 1988 to 1996 at South Prairie Creek at South Prairie, Washington

$\left[\mathrm{ft}^{3} / \mathrm{s}\right.$, cubic feet per second; *, snowmelt peaks are defined as having 3-day basin-averaged snowmelt totals at least 30 percent as much as the basin-averaged 3-day rain totals]

\begin{tabular}{|c|c|c|c|c|c|c|c|}
\hline \multirow[b]{3}{*}{ Water year } & \multicolumn{4}{|c|}{ Peak discharge, in $\mathrm{ft}^{3} / \mathrm{s}$} & \multirow{2}{*}{3 -day ${ }^{1}$ basin-averaged rain } & \multirow{2}{*}{\multicolumn{2}{|c|}{ 3-day basin-averaged snowmelt }} \\
\hline & & & Dif & erence & & & \\
\hline & Observed & Simulated & $\mathrm{ft}^{3} / \mathrm{s}$ & Percent & (inches) $^{2}$ & (inches) $^{3}$ & $(\text { percent })^{4}$ \\
\hline 1950 & 2,930 & 4,134 & 1,204 & 41.1 & 2.32 & 0.52 & 22.4 \\
\hline 1951 & 3550 & 6,208 & 2,658 & 74.9 & 4.01 & 0.77 & 19.2 \\
\hline 1952 & 1,460 & 1,217 & -243 & -16.6 & 1.46 & 0.47 & $32.2 *$ \\
\hline 1953 & 2,660 & 2,133 & -527 & -19.8 & 2.07 & 0.66 & $31.9 *$ \\
\hline 1954 & 5,470 & 5,075 & -395 & -7.2 & 2.60 & 0.51 & 19.6 \\
\hline 1955 & 3,440 & 3,012 & -428 & -12.4 & 2.60 & 0.44 & 16.9 \\
\hline 1956 & 6,850 & 6,814 & -36 & -0.5 & 4.27 & 0.33 & 7.7 \\
\hline 1957 & 2,750 & 2,872 & 122 & 4.4 & 1.70 & 0.51 & $30.0^{*}$ \\
\hline 1958 & 1,710 & 2,704 & 994 & 58.1 & 2.18 & 0.22 & 10.1 \\
\hline 1959 & 3,160 & 1,912 & $-1,248$ & -39.5 & 2.26 & 0.11 & 4.9 \\
\hline 1960 & 3,900 & 4,659 & 759 & 19.5 & 4.06 & 0.52 & 12.8 \\
\hline 1961 & 3,340 & 1,537 & $-1,803$ & -54.0 & 1.51 & 0.55 & $36.4^{*}$ \\
\hline 1962 & 1,760 & 2,079 & 319 & 18.1 & 2.54 & 0.70 & 27.6 \\
\hline 1963 & 3,850 & 4,719 & 869 & 22.6 & 0.97 & 0.20 & 20.6 \\
\hline 1964 & 3,380 & 1,827 & $-1,553$ & -45.9 & 1.25 & 0.30 & 24.0 \\
\hline 1965 & 6,400 & 8,142 & 1,742 & 27.2 & 5.34 & 1.34 & 25.1 \\
\hline 1966 & 985 & 752 & -233 & -23.7 & 0.40 & 0.25 & $62.5^{*}$ \\
\hline 1967 & 1,390 & 2,084 & 694 & 49.9 & 1.90 & 0.30 & 15.8 \\
\hline 1968 & 2,840 & 2,547 & -293 & -10.3 & 2.15 & 0.79 & $36.7^{*}$ \\
\hline 1969 & 3,060 & 4,404 & 1,344 & 43.9 & 3.48 & 0.95 & 27.3 \\
\hline 1970 & 1,890 & 2,198 & 308 & 16.3 & 1.74 & 0.68 & $39.1^{*}$ \\
\hline 1971 & 2,710 & 3,243 & 533 & 19.7 & 1.83 & 0.54 & 29.5 \\
\hline 1972 & 3,410 & 3,174 & -236 & -6.9 & 1.53 & 0.51 & $33.3 *$ \\
\hline 1973 & 2,350 & 2,223 & -127 & -5.4 & 2.09 & 0.36 & 17.2 \\
\hline 1974 & 4,310 & 4,942 & 632 & 14.7 & 4.60 & 1.26 & 27.4 \\
\hline 1975 & 5,020 & 5,359 & 339 & 6.8 & 3.69 & 0.86 & 23.3 \\
\hline 1976 & 4,380 & 3,930 & -450 & -10.3 & 2.76 & 0.77 & 27.9 \\
\hline 1977 & 710 & 608 & -102 & -14.4 & 0.95 & 0.41 & $43.2^{*}$ \\
\hline 1978 & 3,700 & 3,632 & -68 & -1.8 & 4.24 & 0.45 & 10.6 \\
\hline 1979 & 2,770 & 2,325 & -445 & -16.1 & 1.48 & 0.40 & 27.0 \\
\hline 1988 & 2,190 & 1,948 & -242 & -11.1 & 1.92 & 0.17 & 8.9 \\
\hline 1989 & 2,440 & 870 & $-1,570$ & -64.3 & 3.47 & 0.00 & 0.0 \\
\hline 1990 & 5,930 & 6,182 & 252 & 4.2 & 4.55 & 0.26 & 5.7 \\
\hline 1991 & 5,390 & 7,241 & 1,851 & 34.3 & 3.88 & 0.27 & 7.0 \\
\hline 1992 & 1,700 & 2,198 & 498 & 29.3 & 2.41 & 0.13 & 5.4 \\
\hline 1993 & 2,630 & 1,523 & $-1,107$ & -42.1 & 1.09 & 0.36 & $33.0^{*}$ \\
\hline 1994 & 1,500 & 3,125 & 1,625 & 108.3 & 1.91 & 0.52 & 27.2 \\
\hline 1995 & 2,800 & 4,757 & 1,957 & 69.9 & 3.77 & 0.56 & 14.9 \\
\hline 1996 & 8,200 & 8,804 & 604 & 7.4 & 7.32 & 1.59 & 21.7 \\
\hline
\end{tabular}

${ }^{1}$ The 3-day period begins at midnight 3 days before the peak discharge date and ends at midnight on the day of the peak.

${ }^{2}$ Hourly precipitation was applied by the SSARR model to each elevation zone. If the air temperature for the midpoint of the zone was above 34.0 degrees Fahrenheit, then the precipitation was considered rain and added to the a total; otherwise, the precipitation was not added to the total. Zone totals were added together and aerial weighted according to the size of the zone divided by the total area of the basin.

${ }^{3}$ Aerial-weighted zonal totals of simulated snowmelt including ground melt of the snowpack.

${ }^{4}$ (3-day snowmelt / 3-day rain)x 100 . 
The February 1996 flood (fig. 11) had the largest simulated 3-day total of rain and snowmelt total and simulated and observed peak discharge in the record. The model generally simulated the correct shape of the hydrograph and closely estimated the peak, missing by only 7.4 percent. Figure 1 also shows the simulated basin-averaged rain and snowmelt totals for the 7 days shown. The 3-day totals are used to classify and compare different types of flooding (table 5). There was 1.59 inches of snowmelt for the 3-day period or 21.7 percent (1.59/ $7.32 \times 100$ ) of the precipitation as rain, indicating that this flood was not a "snowmelt peak."

The sources of difference between simulated and observed peak discharges can be attributed primarily to (1) errors in the precipitation and temperature time series inputs, (2) errors in the measurement and calculation of observed discharge, (3) errors in the representation of the hydrologic processes by the SSARR model, and (4) errors in the SSARR model in simulating the spatial variability of the precipitation and temperature inputs from point values at Mud Mountain. Reservoir. These errors are difficult to assess, but any one of the errors can be significant.

As seen graphically on figure 12 , the South Prairie model as used in this investigation has a bias of overestimating peak discharges. Average bias equals $204 \mathrm{ft}^{3} / \mathrm{s}$ and percent bias equals 6.7 percent computed as follows:

$$
\begin{aligned}
\text { Bias } & =\Sigma\left(\frac{(S-O)}{n}\right) \\
\text { Percent Bias } & =100 \times \sum\left(\frac{\left(\frac{S-O}{O}\right)}{n}\right),
\end{aligned}
$$

where $S$ is simulated value, $O$ is observed value, and $n$ is number of values. The bias appears to be greatest for the higher discharges (fig. 12), which is a concern because it may affect the trend analysis in the next section if the flood history is also biased with higher annual peak discharges occurring in one period relative to another. An analysis of the model residuals (simulated annual peak discharge minus observed annual peak discharge) with time should reveal a trend if this is a problem. A plot of the model residuals against time (fig. 13) showed no obvious trend or bias in the values, and the lack of a trend was confirmed with a Mann-Kendall test for trends (tau $=0.0526$, Kendall's test statistic, $S$, had a p-value of 0.65 ).

Regression of the observed and simulated annual peak discharges is shown on figure 12 . The $R^{2}$ is 0.767 and the standard error of regression is $814 \mathrm{ft}^{3} / \mathrm{s}$. A plot of the residuals from the regression plotted with time (fig. 14) shows less scatter of the data than the plot of annual peaks versus time (fig 10), indicating that the introduction of the exogenous variable has been successful in reducing the background noise but no trends are immediately evident. Those peaks classified as snowmelt peaks are shown and tend to be randomly located, indicating that there is no strong bias in the model for this type of flooding.

\section{Trends in Annual Peak Discharge Using an Exogenous Variable}

Two statistical tests, one parametric (which assumes a normal distribution of the data) and the other non-parametric, were used to test for trends in the annual peak discharge time series. Both tests show that there is not enough evidence to conclude that there is a trend.

The annual peak discharges were regressed against time and the exogenous variable, simulated peak discharge, to test for a trend in flooding, that is, that the slope of the time variable in the regression equation is significantly different from zero. The results of the regression (table 6) show that while the simulated peak discharge is a statistically significant parameter in the regression with a $\mathrm{p}$-value less than 0.0001 ( $\mathrm{p}$ is the probability that the regression coefficient for a parameter is zero), the coefficient for water year (time) is not significantly different from zero ( $p$-value $=0.9141$ ). Therefore, there is not enough evidence to conclude that a trend exists, and in fact, the water year estimate is negative, which implies that if a trend truly existed, it would most likely be a decreasing potential for flooding with time.

Table 6. Results of multiple linear regression of observed annual peak discharge with water year and simulated peak discharge

[PEAKQ, observed annual peak discharge; SIMQ, simulated annual peak discharge; $W Y$, water year; $\mathrm{p}$, probability that the regression coefficient for a parameter is zero]

$$
P E A K Q=2,857-1.037 W Y+0.709 \text { SIMQ }
$$

\begin{tabular}{lrrl}
\hline Parameter & Estimate & \multicolumn{1}{l}{$\begin{array}{l}\text { Standard } \\
\text { error }\end{array}$} & \multicolumn{1}{l}{$\mathrm{p}$} \\
\hline Intercept & 2,857 & 18,797 & 0.88 \\
SIMQ & 0.709 & 0.065 & 0.0001 \\
$W Y$ & -1.037 & 9.548 & 0.91 \\
\hline
\end{tabular}



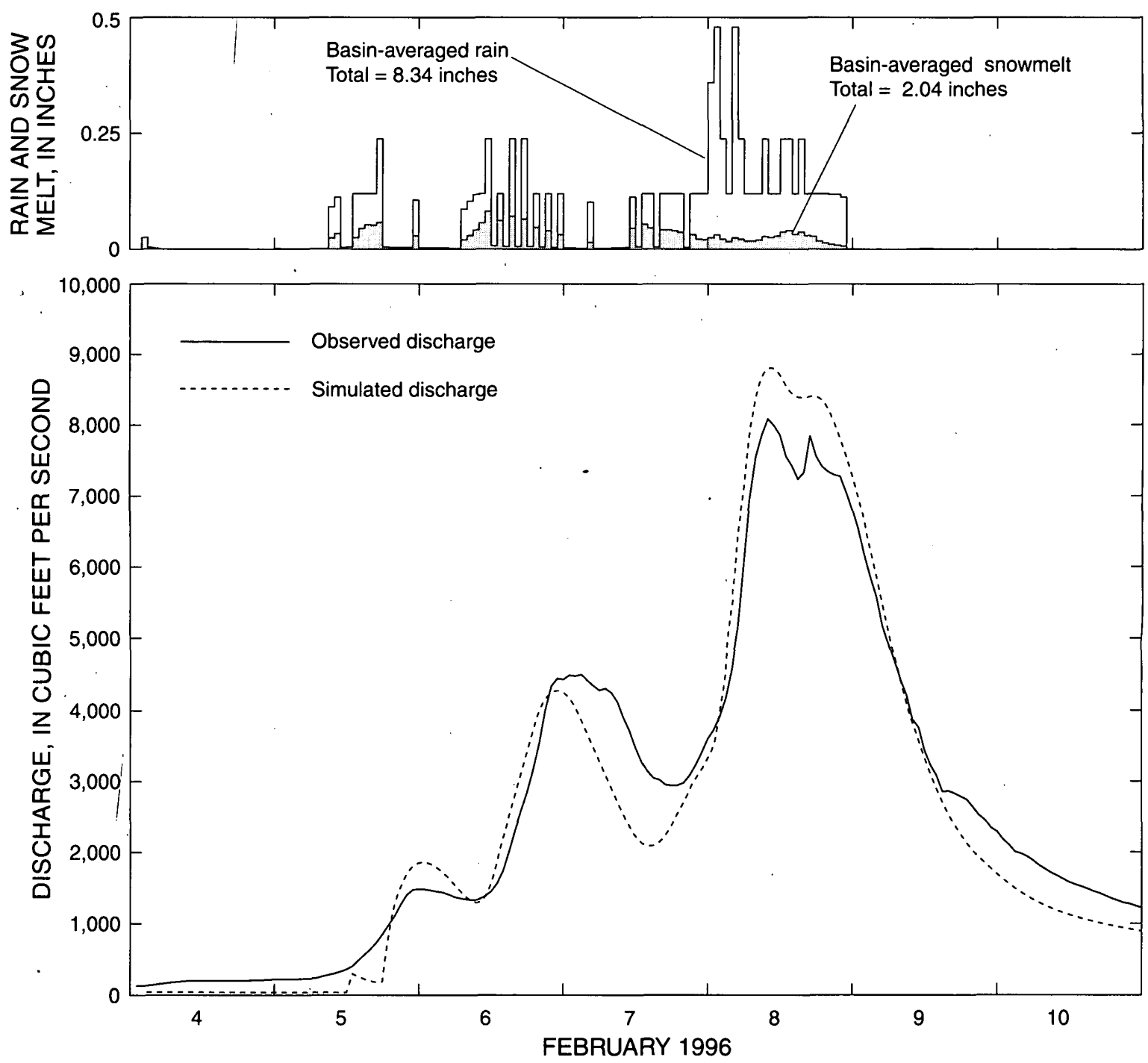

Figure 11. Observed and simulated discharge and basin-averaged rain and snowmelt for February $4-10,1996$, at South Prairie Creek, Washington (station number 12095000). 


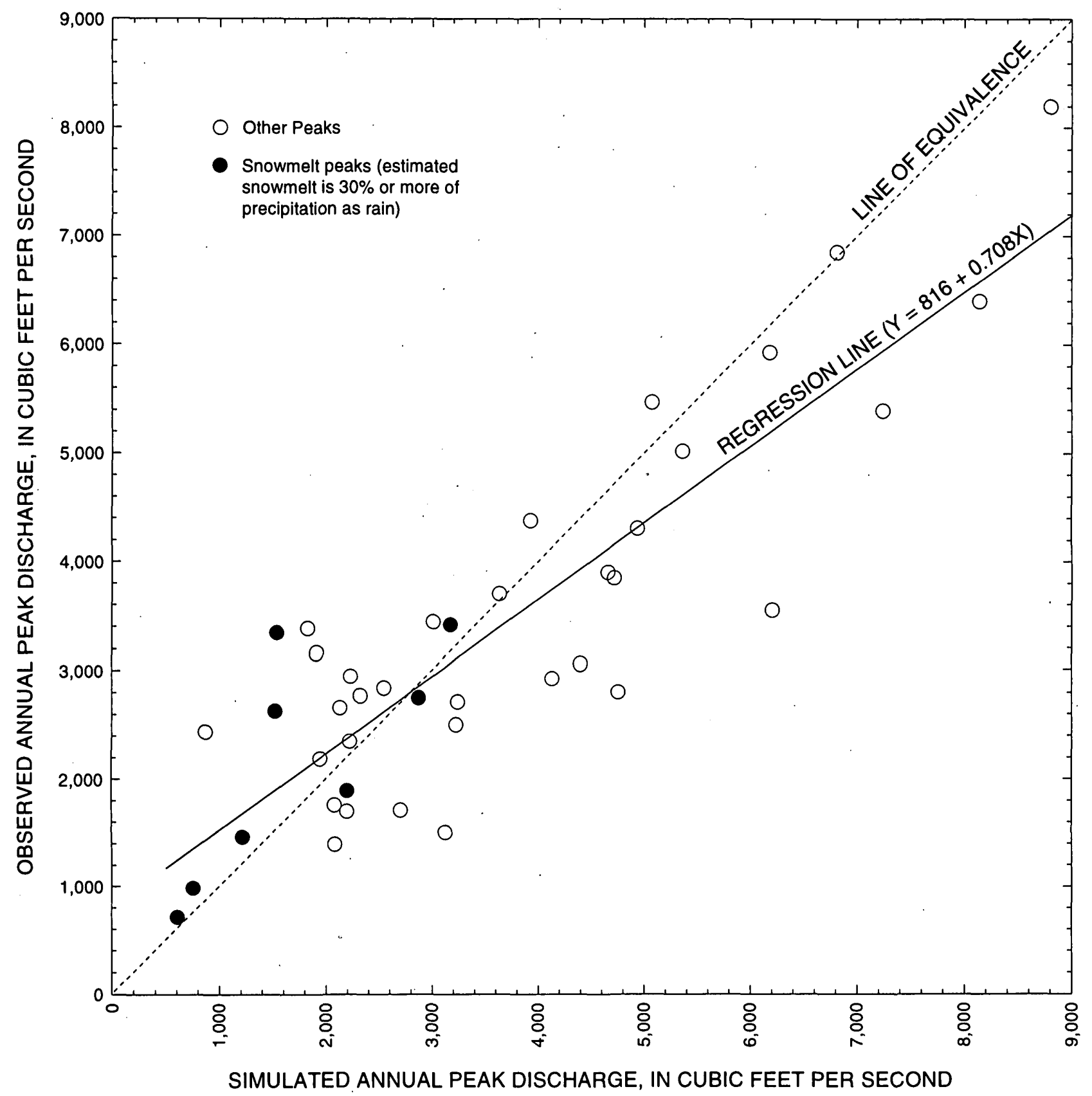

Figure 12. Observed and simulated annual peak discharge of South Prairie (station number 1209500) during water years 1950-1979 and 1988-1996. 


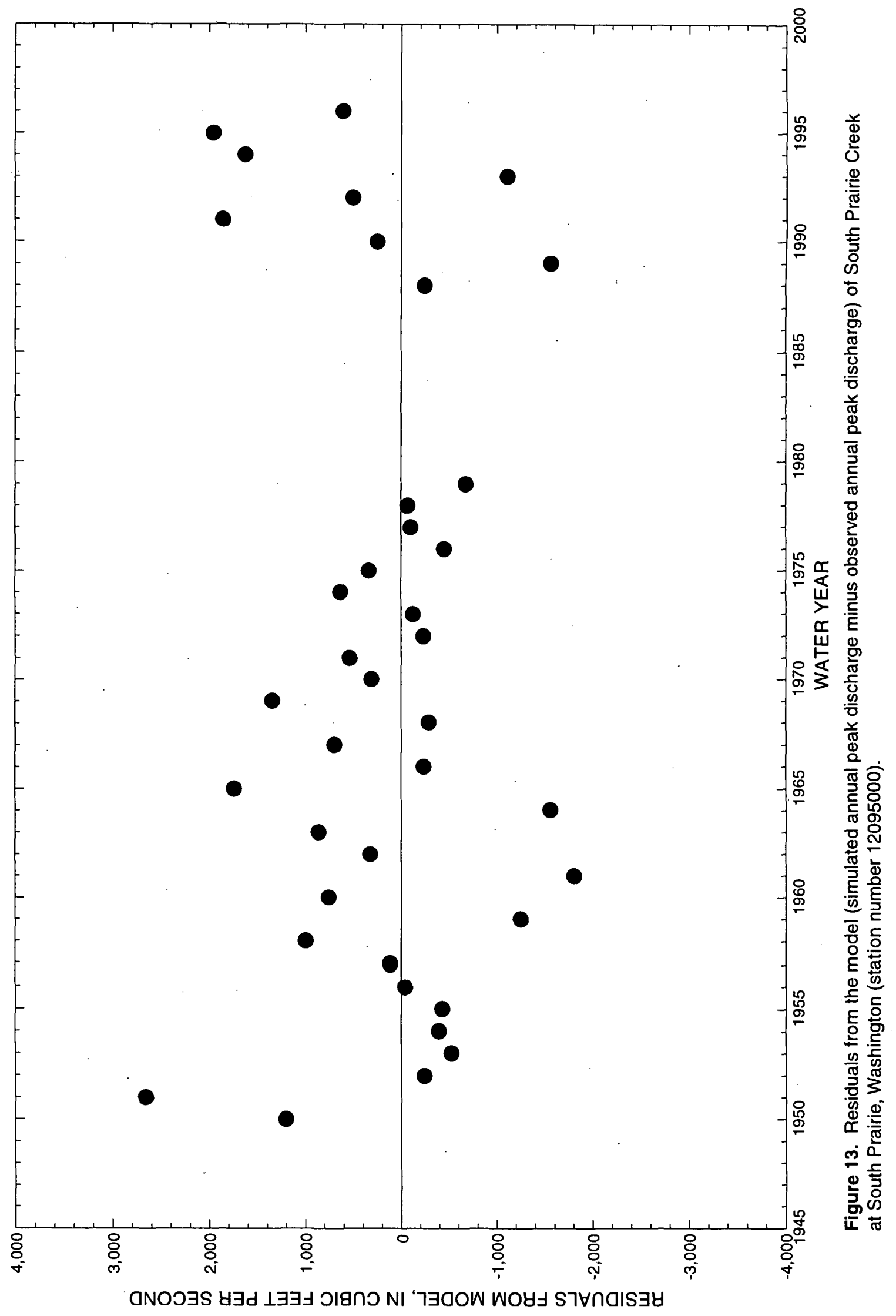




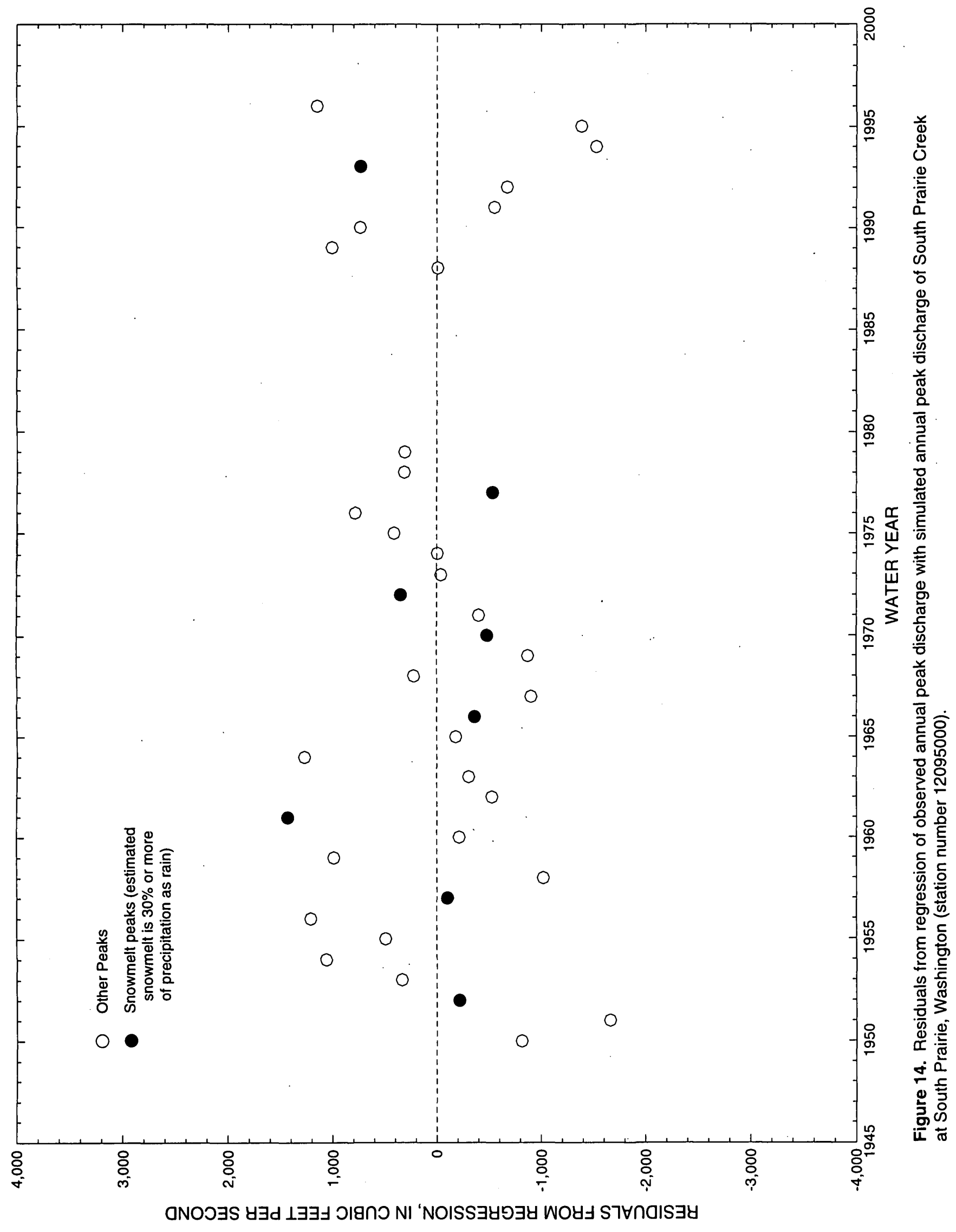


The non-parametric test LOWESS, or LOcally WEighted Scatterplot Smoothing (Helsel and Hirsch, 1995), was performed to compute a weighted least-squares regression of observed annual peak discharges with simulated peak discharges (fig. 15). The LOWESS uses an iterative process to determine the weights in the regression as a function of the distance from the center of a window that moves in the $\mathrm{X}$ direction and whose size is a function of a smoothing factor ( 0.5 was used in this application) and the magnitude of the residual from the previous regression. The LOWESS procedure has the advantage of not requiring the regression to be linear. The Mann-Kendall test for trends was subsequently performed on the residuals of the LOWESS fit (fig. 16). In this test, Kendall's tau correlation coefficient was -0.020 , indicating a slight decreasing trend with time, and Kendall's test statistic, $S$, had a p-value of 0.865 , indicating that there is not enough evidence to refute the null hypothesis that there is no trend of increasing or decreasing peak discharges with time. Similar results were computed for a Mann-Kendall test for the residuals from the regression of observed annual peak discharge with simulated annual peak discharge (fig. 14).

Kendall tau correlation coefficient was -0.009 and Kendall's $S$ had a p-value of 0.942 .
To investigate the possibility that there may be trends in the climate variables that mask or negate any trend in the magnitude or frequency of flooding on South Prairie Creek, annual precipitation and annual mean temperature during the period of 1950 to 1995 for four nearby NWS weather stations were plotted (fig. 17) and analyzed for trends (table 7). Using the same linear regression and Mann-Kendall trend tests described earlier, no significant trend was found, except for the annual mean temperature at the NWS station Mud Mountain Dam, which increased slightly with time. In the regression equation with time, the probability that the time coefficient in the regression equation is zero is low (less than 2 percent), but the coefficient of determination is also low (0.206). How this may influence flooding in the South Prairie Creek Basin is difficult to quantify. Because no significant trend and only a weak indication of a decreasing trend was evident in the statistical analysis of the peak discharges on South Prairie Creek, one obvious conclusion is that no significant increasing trend in flooding was obscured by a detected trend in temperature or by precipitation.

Table 7. Results of linear regression of year with annual precipitation and annual mean temperature and Mann-Kendall trend test with the available record at four National Weather Service stations for calendar years 1950-95 in or near the South Prairie Creek Basin, Washington

$\left[R^{2}\right.$ is the coefficient of determination; $p$ value is the level of significance of the slope of the time variable, calendar year, in the regression equation; Kendall's tau in the Mann-Kendall trend test is analogous to $\mathrm{R}^{2}$ in the linear regression equation; RS, ranger station]

\begin{tabular}{|c|c|c|c|c|c|c|c|c|}
\hline & \multicolumn{4}{|c|}{ Annual precipitation } & \multicolumn{4}{|c|}{ Annual mean temperature } \\
\hline & \multicolumn{2}{|c|}{ Linear regression } & \multicolumn{2}{|c|}{ Mann-Kendall } & \multicolumn{2}{|c|}{ Linear regression } & \multicolumn{2}{|c|}{ Mann-Kendall } \\
\hline & $\mathrm{R}^{2}$ & $\mathrm{p}$-value & tau & p-value & $\mathrm{R}^{2}$ & p-value & tau & $\mathrm{p}$-value \\
\hline McMillin. Reservoir & 0.001 & 0.85 & -0.049 & 0.64 & 0.049 & 0.14 & 0.148 & 0.17 \\
\hline Mud Mountain Reservoir & 0.025 & 0.29 & 0.079 & 0.47 & 0.206 & 0.0017 & 0.334 & 0.0018 \\
\hline Rainier Longmire RS & 0.031 & 0.24 & -0.168 & 0.12 & 0.005 & 0.63 & -0.055 & 0.62 \\
\hline Rainier Paradise RNGR & 0.007 & 0.62 & -0.041 & 0.79 & 0.069 & 0.12 & -0.141 & 0.40 \\
\hline
\end{tabular}




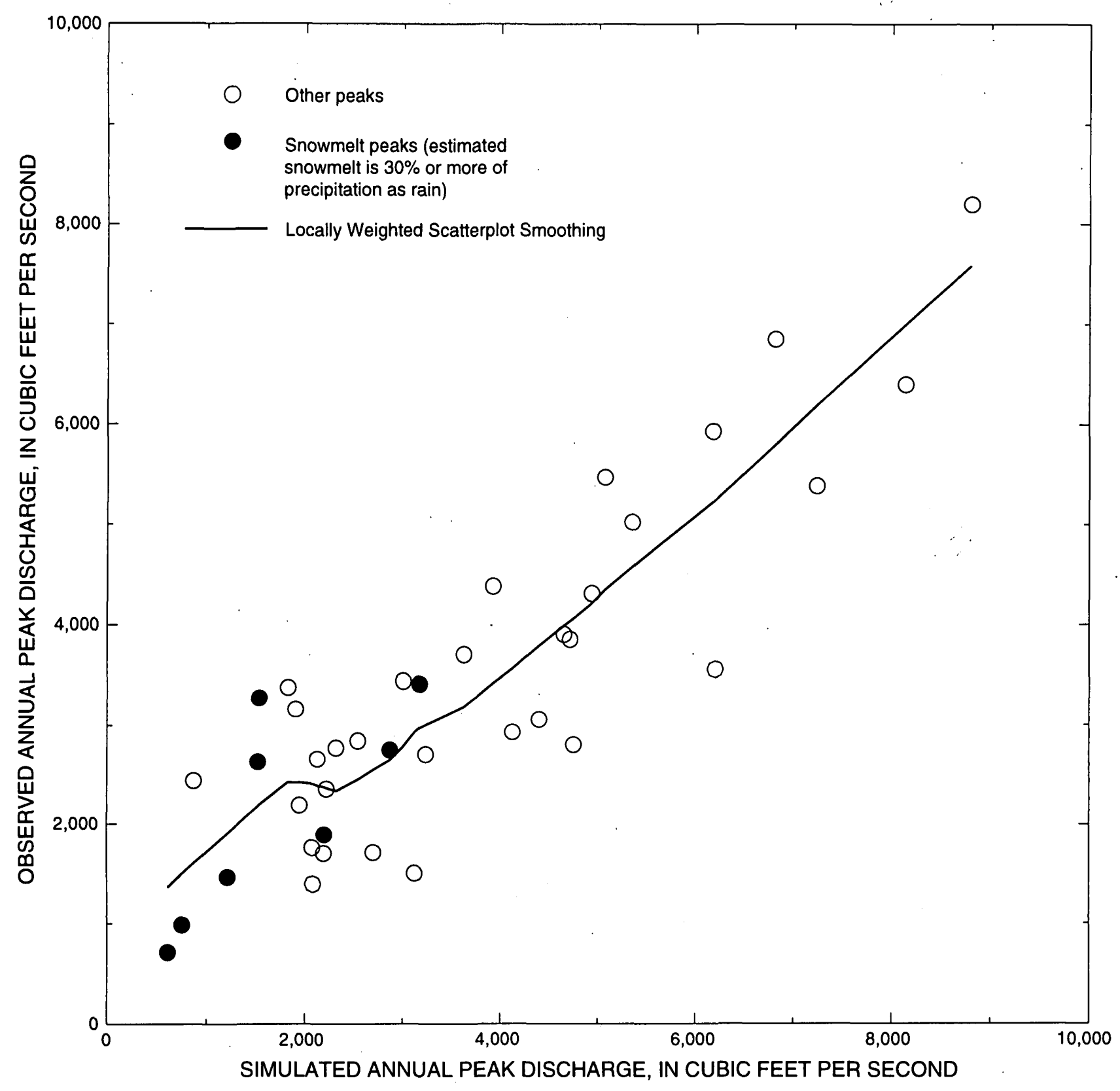

Figure 15. Locally Weighted Scatterplot Smoothing (LOWESS) regression of observed annual peak discharged against simulated annual peak discharge for South Prairie Creek at South Prairie, Washington (station number 12095000). 


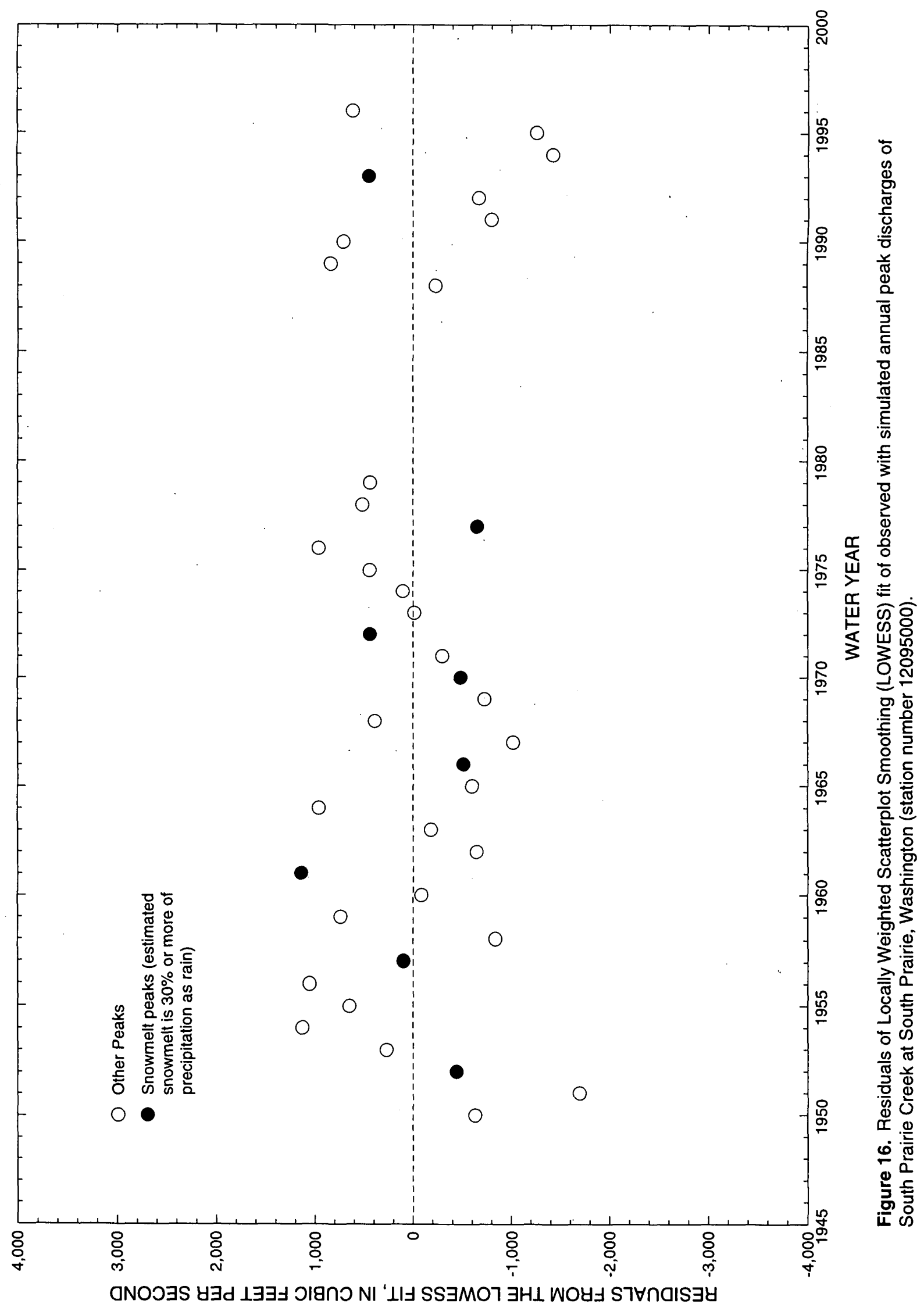




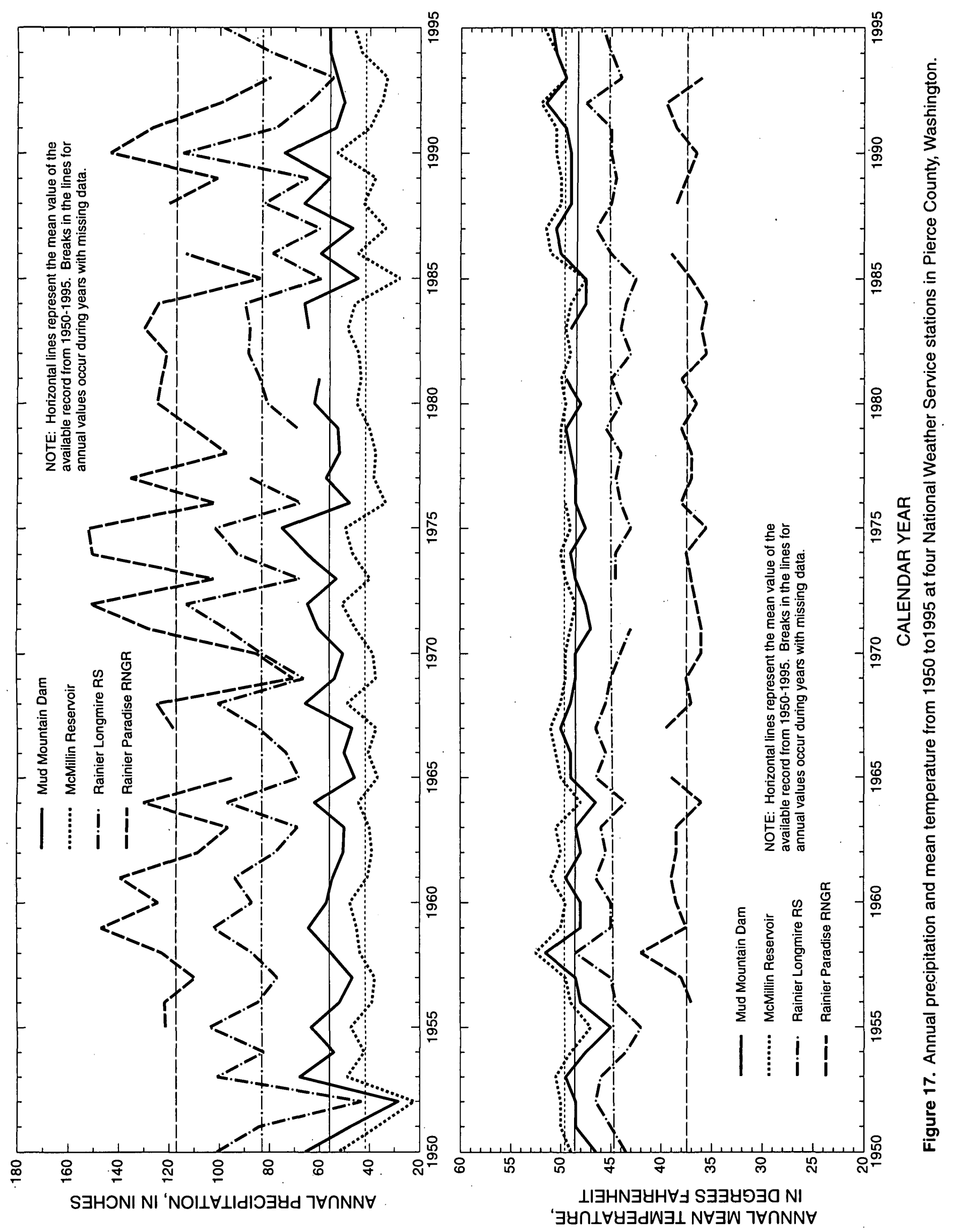




\section{FLOOD INUNDATION}

There are two basic elements in the examination of potential flood inundation by a stream: one is the magnitude of the flood and the other is the flood-carrying capacity of the stream channel. How these two elements were computed and how the information was translated to define those areas in the lower South Prairie Creek floodplain that are prone to floods of various sizes will be discussed in this section. In this section, (1) the computation of the recurrence interval of various magnitudes of floods with the available record of annual peak-flow data is discussed; (2) available floodplain and channel cross-sectional data to show the changes or lack of changes that have occurred and how they affect the flood-carrying capacity of the stream are compared; (3) the construction of a computer model to estimate water-surface profiles along the creek for floods of various magnitudes is described; and (4) a flood-inundation map for the current conditions of South Prairie Creek for various flood magnitudes is constructed.

Floodplain and channel cross sections on lower South Prairie Creek were surveyed at three hydrologically distinct times. The first and most comprehensive survey was done in 1976 and 1977 as part of the FEMA National Flood Insurance Program (Federal Emergency Management Agency, 1981 and 1987). It included 51 cross sections from the mouth of South Prairie Creek to a location just upstream of the town of South Prairie. A second set of 28 cross sections was surveyed during the period from October 1994 to December 1995. These cross sections were located mostly at the same locations as some of the 1976-77 cross sections. Comparison of the 197677 baseline data to the second set of cross-section data represents the change over approximately two decades. In the third survey soon after the 1996 flood, 13 cross sections were resurveyed at the same locations as some of the 1994-95 cross sections (3 more supplemental cross sections were also surveyed where water flows out of the main channel banks). Comparison of cross sections from the first and second surveys were used to evaluate channel changes over a period of about 2 decades when much of the upper watershed logging occurred. Literature suggests that this logging activity may have greatly increased the sediment load of the stream, thereby reducing its channel capacity and raising the flood elevations for a given discharge over the elevations estimated in the flood-insurance study. The 1996 flood was a major flood on the creek that provided an opportunity to document the changes that can occur in the channel geometry as a result of a flood.
The original survey established a network of elevation reference marks using the National Geodetic Vertical Datum of 1929 (NGVD). Aerial photogrammetry was used to create topographic maps and cross-section data for the above-water portion of the channel and floodplains, and field surveys provided data on the underwater parts. The locations of the cross sections were shown on the aerial photographs without precise horizontal control (David L. Kresch, U.S. Geological Survey, oral commun., 1995). The photographs used to identify cross-section locations for the 1976-77 survey were also used to locate the cross sections surveyed in 1994-95, but the locations are believed to be accurate to within only about 50 feet of the original locations, except at the downstream ends of bridges, where the locations are accurate within about 5 feet. As a part of this study, a network of eight bench marks was established on October 11, 1994, for horizontal and vertical control using satellite-based Global Positioning System (GPS) techniques. The horizontal accuracy of these benchmarks is within 0.2 feet. The elevations were corrected to the elevation reference marks used in the 1976-77 survey. All cross sections were located horizontally and vertically using both the elevation and GPS reference marks. Coordinates were projected to Washington State Plane Coordinate System South (NAD83) to agree with the 1987, 1:600 scale, 1- and 2-foot contour base maps of South Prairie Creek provided by Pierce County for the delineation of the flood inundation areas.

\section{Flood Frequency}

Because no trends in flood-frequency of South Prairie Creek were detected, the entire period of record can be used to estimate the flood-frequency distribution for the stream. An annual-peak-flow frequency analysis using the Pearson Type III distribution with log transformation of the discharge following Bulletin 17-B guidelines (U.S. Water Resources Council, 1981) was performed on the 39 annual peak discharges recorded at the gaging station. One low outlier (water year 1977, $710 \mathrm{ft}^{3} / \mathrm{s}$ ) was dropped from the analysis because it was less than a low outlier threshold of $715 \mathrm{ft}^{3} / \mathrm{s}$ (calculated in accordance with Bulletin 17-B), and a weighted skew of -0.079 was used. The weighted skew was calculated using the generalized skew of 0.002 and the station skew of -0.429 . The estimated discharges for various annual exceedance probabilities are shown in table 8 and plotted on figure 18. 
Exceedance probability is the inverse of the more commonly used term "recurrence interval." For example, an annual peak flow with an exceedance probability of 0.02 is equivalent to a 50 -year recurrence interval flood $(1 / 0.02=50)$ or simply "50-year flood," which has a statistical probability of being equaled or exceeded 2 times in 100 years on the average or a 2-percent chance of being equaled or exceeded in any one year.

Discharges used in the water-surface profile computations correspond to the 10-, 50-, 100-, and 500-year floods $\left(5,520 ; 7,910 ; 8,960\right.$; and $11,500 \mathrm{ft}^{3} / \mathrm{s}$, respectively) at the upstream end of the study reach where they were computed for the gaging station at South Prairie. At cross section 280 just below several small tributaries to South Prairie Creek, whose combined drainage area equals about 4 percent of the drainage area above the gaging station, 4 percent was added to the discharges. These larger discharge figures $(5,740 ; 8,230 ; 9,320 ; 12,000)$ were used from the mouth to cross section 280 and then reduced to the lower set of discharges for all the remaining cross sections upstream.

\section{Comparisons of Channel Cross Sections}

Figure 19 shows the locations of the cross sections and six bridges numbered 1 (farthest downstream) to 6 (farthest upstream) for this study. All the bridges are on Washington State Route 162, except for Bridge 6, which is on an abandoned railroad line. More detailed locations are shown on figures 20 through 23, which show the stationing, in feet, above the mouth of South Prairie Creek to each cross section. Bridge cross sections, located at the downstream ends of bridge openings, were given identifiers in the form of BRG\# ("\#" refers to the bridge numbers from 1 to 6). APPR\# was the naming convention for bridge approach cross sections, which were generally located about one bridge width upstream of the bridge. EXIT\# was the naming convention for bridge exit cross sections generally located about one bridge width downstream of the bridge. OVRFL\# was the naming convention for cross sections on small overflow channels just upstream of bridges used to compute road overflow discharges and water-surface levels.

Table 8. Selected annual peak-flow exceedance probabilities for South Prairie Creek at South Prairie, Washington (Station number 12095000)

\begin{tabular}{lcccc}
\hline $\begin{array}{l}\text { Annual } \\
\text { exceedance } \\
\text { probability }\end{array}$ & $\begin{array}{l}\text { Recurrence } \\
\text { interval } \\
\text { (years) }\end{array}$ & $\begin{array}{l}\text { Discharge } \\
\text { (cubic feet } \\
\text { per second) }\end{array}$ & \multicolumn{2}{c}{$\begin{array}{c}\text { 95-percent confidence limits } \\
\text { (cubic feet per second) }\end{array}$} \\
\hline 0.950 & 1.05 & 1,320 & Lower & Upper \\
0.900 & 1.11 & 1,590 & 1,040 & 1,580 \\
0.800 & 1.25 & 1,980 & 1,300 & 1,860 \\
0.500 & 2.00 & 2,990 & 1,670 & 2,270 \\
0.200 & 5.00 & 4,480 & 2,630 & 3,410 \\
0.100 & 10.0 & 5,520 & 3,910 & 5,310 \\
0.040 & 25.0 & 6,870 & 4,730 & 6,750 \\
0.020 & 50.0 & 7,910 & 5,750 & 8,740 \\
0.010 & 100 & 8,960 & 6,500 & 10,300 \\
0.005 & 200 & 10,000 & 7,250 & 12,000 \\
0.002 & 500 & 11,500 & 8,000 & 13,800 \\
\hline
\end{tabular}




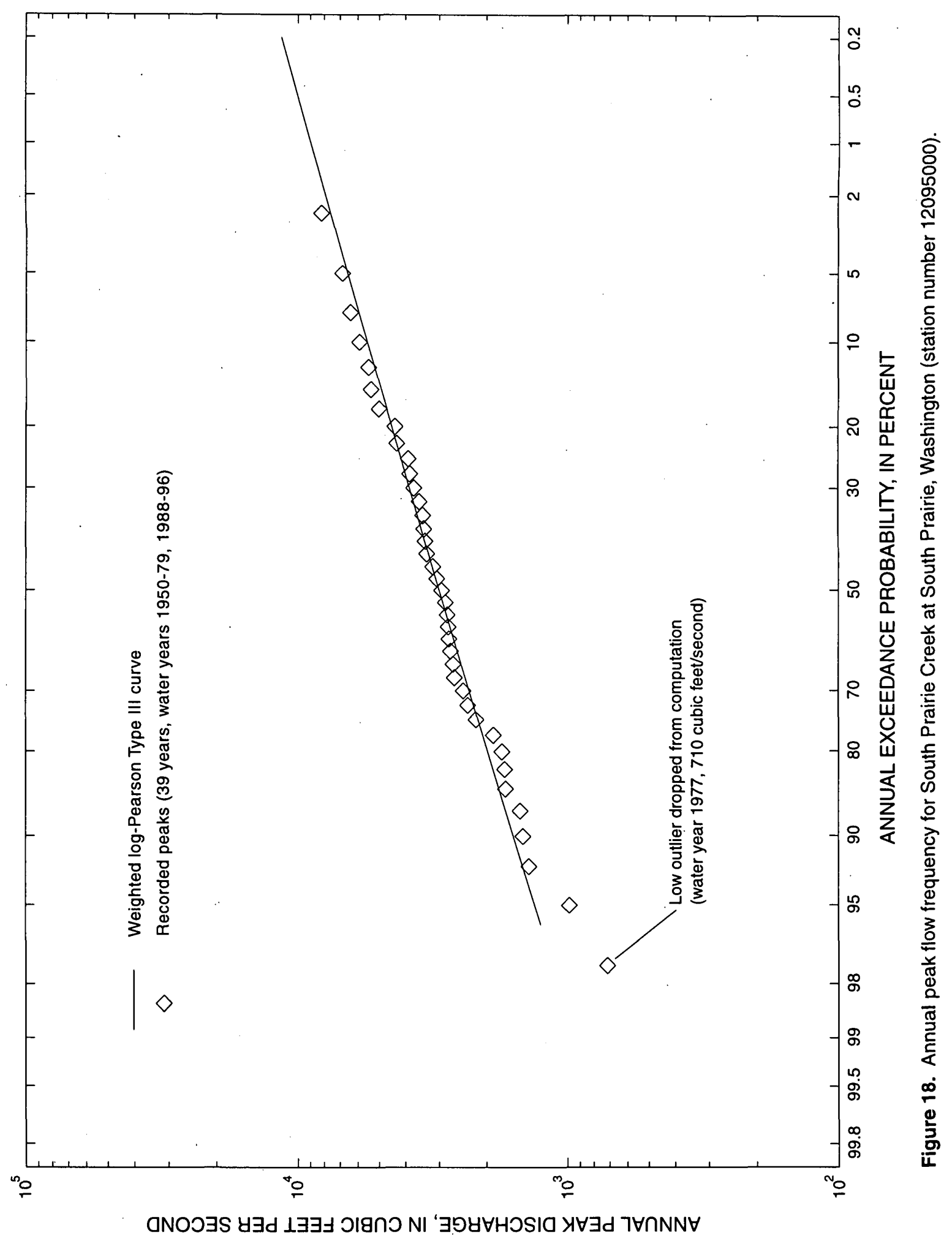




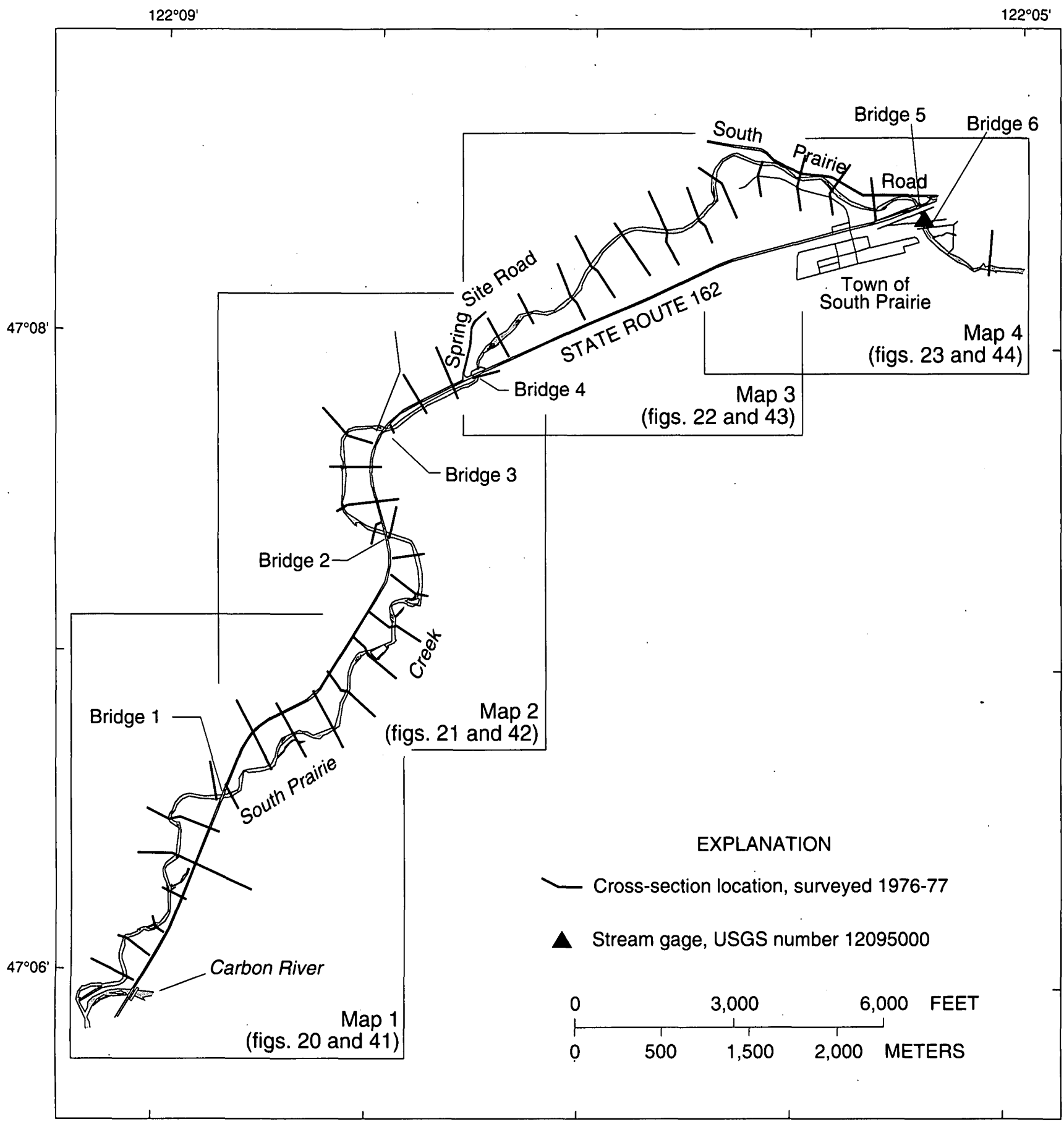

Figure 19. Index to maps (figures 20 to 23 and 41 to 44 ) of lower South Prairie Creek, Washington. 


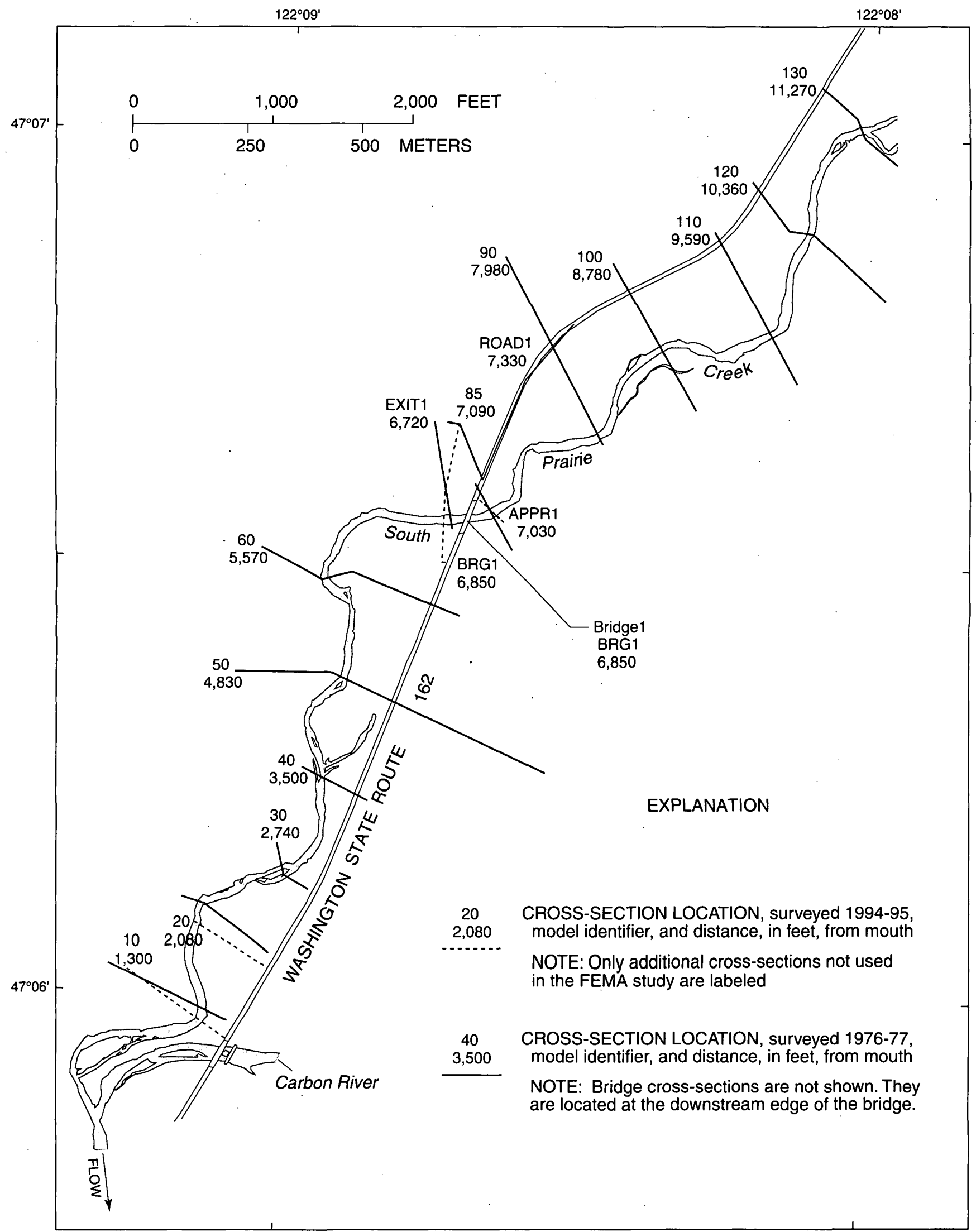

Figure 20. Lower South Prairie Creek, Washington, showing cross-section locations (Map 1 of 4). 


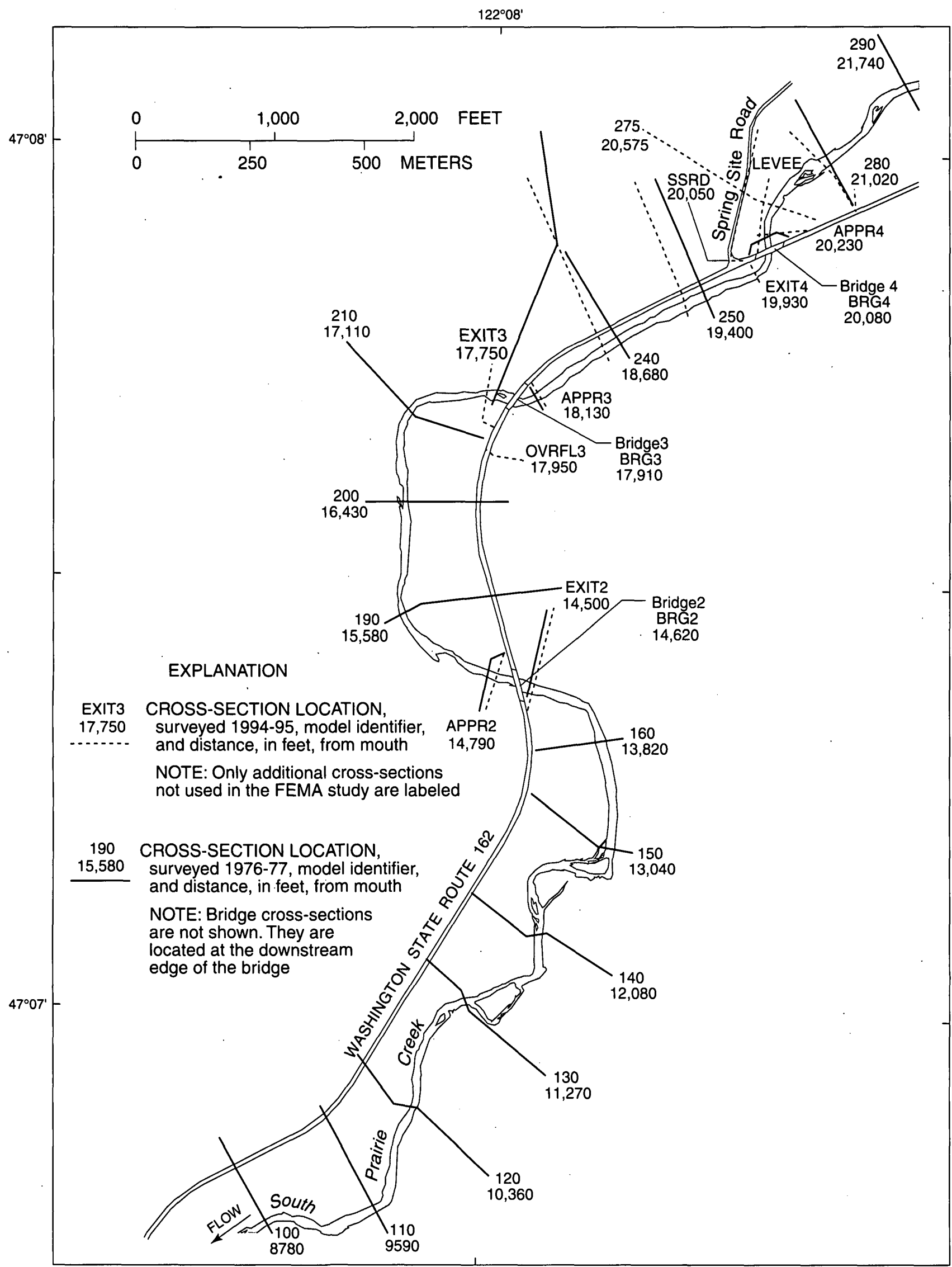

Figure 21. Lower South Prairie Creek, Washington, showing cross-section locations (Map 2 of 4). 


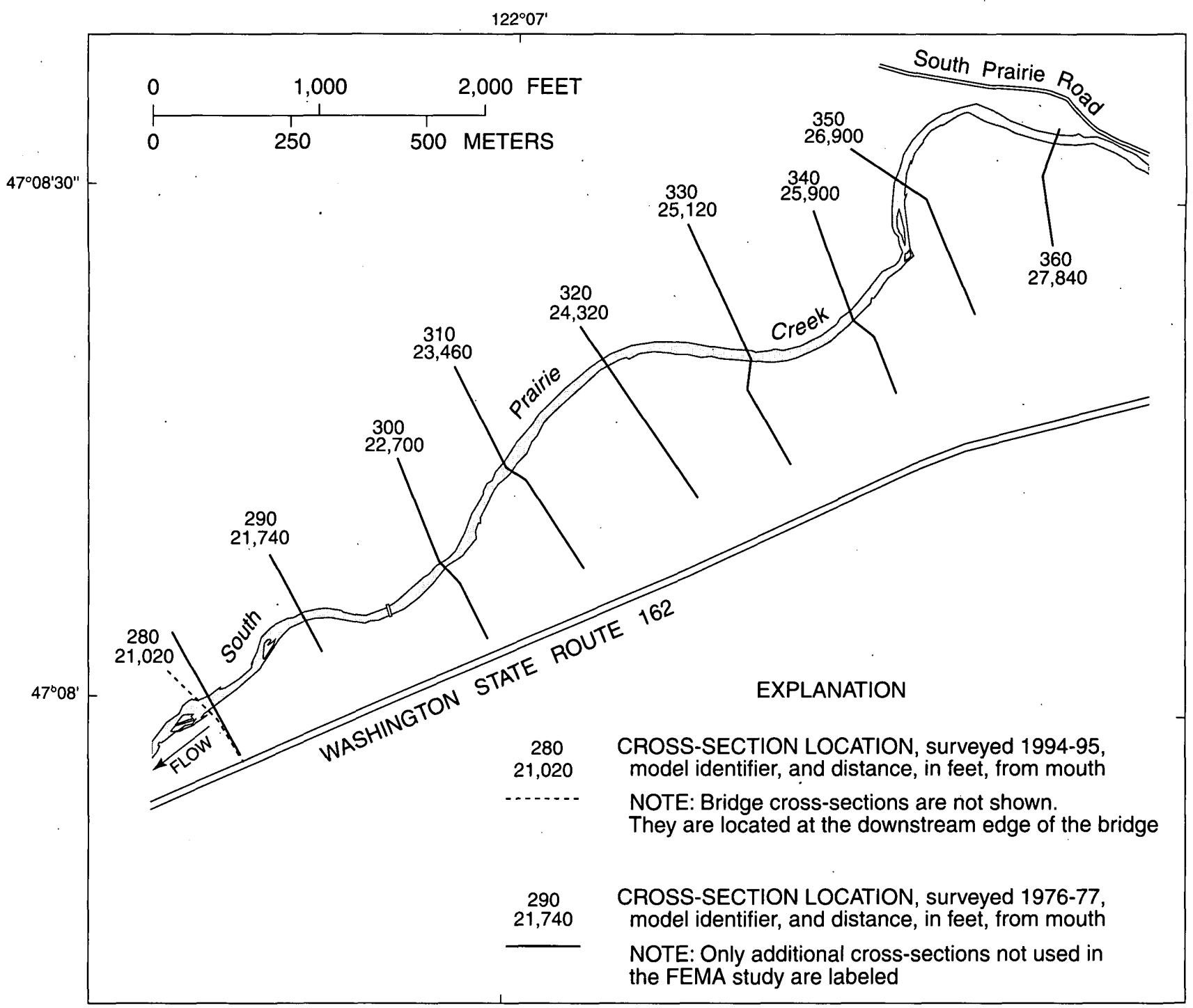

Figure 22. Lower South Prairie Creek, Washington, showing cross-section locations (Map 3 of 4). 


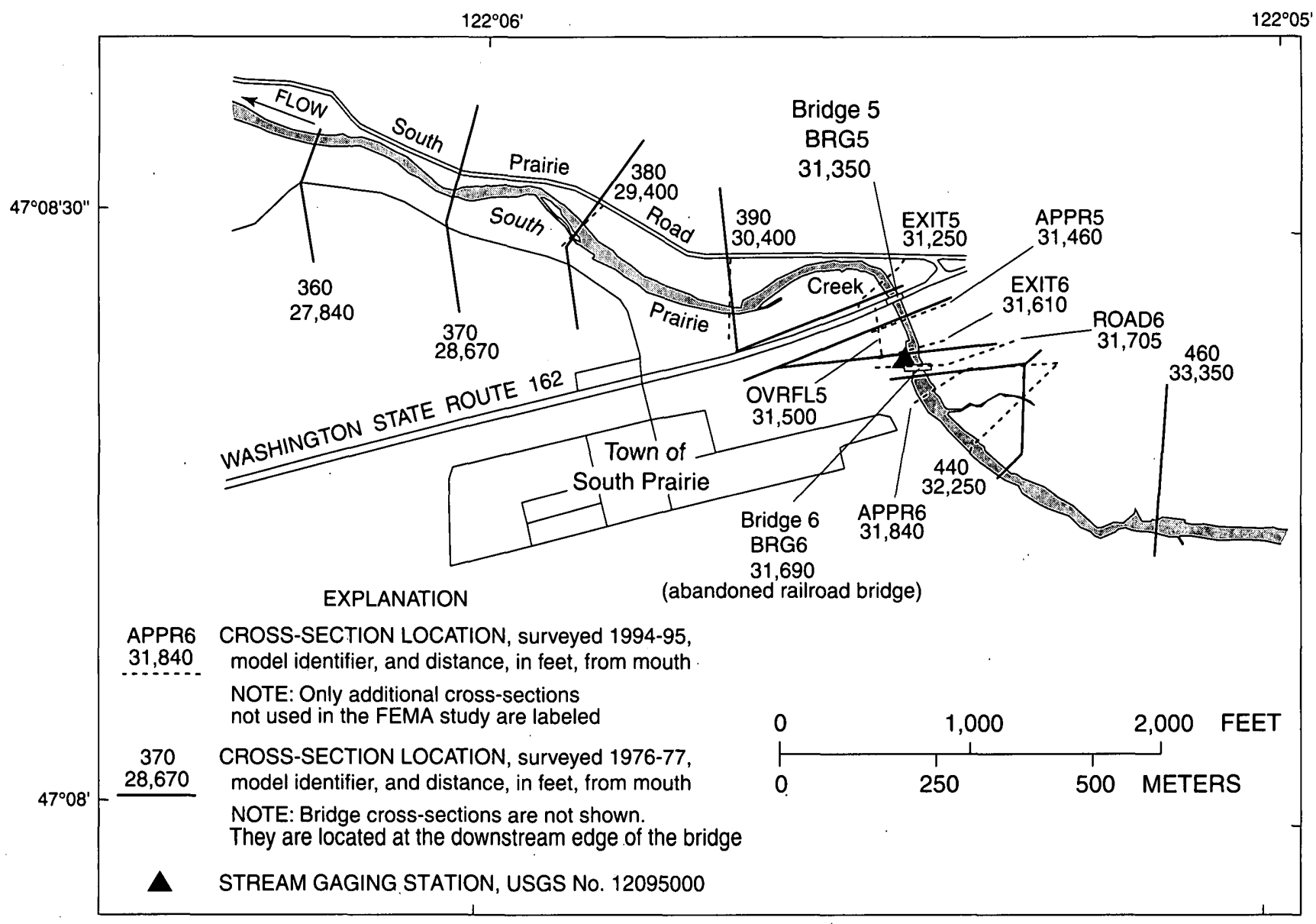

Figure 23. Lower South Prairie Creek, Washington, showing cross-section locations (Map 4 of 4). 
Figures 24 through 33 show selected cross sections throughout the reach. Because the end points of the cross sections used in the 1976-77 flood insurance study were not monumented, it is impossible to know whether or not later surveys were made at exactly the same locations, but it is believed that resurveyed bridge sections were within about 5 feet of their original locations and that all other resurveyed sections were within about 50 feet of their original locations. The beginning stationing on a cross section starts on the left bank and is given an arbitrary value. Successive cross sections at the same location were lined up as well as possible, but since they were not in the exact same location, the banks and other features are not always in alignment. What may appear as fill or scour along the banks is probably only a misalignment of the cross sections. The set of cross sections surveyed in 1996 were located at previously surveyed (1994-95) locations that appeared to have changed the most, as indicated by field inspections following the February 8, 1996, flood.

Figures 24 through 26 show all the cross sections that are at the downstream ends of the bridges. Little change is evident between the surveys, except at Bridge 4 (cross section BRG4). At this site, the bed aggraded about 4 feet in the center of the channel (station 80 ) in the period between the 1976-77 survey and the 1995 survey, but scoured about 5 feet near the right bank (fig. 25, station 160). The channel bed appears to be quite dynamic during floods, as shown by the changes between the 1995 and 1996 surveys, although the flood-carrying capacity through the bridge has remained approximately the same.

Figures 27 through 29 show the approach and exit cross sections to Bridges 3, 4, and 5. All of the cross sections appear to be relatively stable except for approach cross section APPR4. During the February 1996 flood, the levee failed and floodwaters left the channel, traveled across Spring Site Road, eroded much of the Solar Farms' pastures, and flooded several houses before returning to the main channel downstream of Bridge 3 . The levee was rebuilt quickly after the flood, and much of the eroded portion of Solar Farms was filled before the 1996 survey was made. Cross section 250 (fig. 31) and cross section 275 (fig. 32) also show some of the erosive nature of the flood in this vicinity. Note that the left bank for cross section 250 (fig. 31) does not match up well for the two surveys. This is most likely due to a misalignment of the two cross section surveys and not due to aggradation of the streambed.
Figures 30 to 32 show much of the same-relatively stable channel geometry from 1976-77 to the present. Figure 33, however, shows a more dynamic condition for cross section 380 and especially at cross section 390 , where the bed was raised about 4 feet (station 130) by the February 1996 flood to a position similar to the 1976-77 level.

Overall, the cross sections show no trend of filling or scouring that might have changed the flooding potential between 1976-77 and 1996 given the same discharge. Therefore, many of the 1976-77 cross sections were not resurveyed in 1995 and 1996 because the stability of the channel as seen in the resurveyed cross sections suggested that the data from the 1976-77 cross sections could be used again for the current flood-inundation analysis.

\section{Estimating Water-Surface Profiles}

Water-surface profiles for peak discharges were computed using standard step-backwater methods and data collected from the cross-section surveys. U.S. Geological Survey Water-Surface PROfile computer program (WSPRO) was used to make the step-backwater computations for this investigation. The program, which is onedimensional and designed to be used for open-channel flow conditions, can be used to estimate profiles in channels with variable roughness coefficients and various configurations such as flow through bridge openings and road overflows. More in-depth explanation of the computer program is given by Shearman and others (1986), and the theory of the step-backwater method is given by Davidian (1984).

The step-backwater method requires definition of channel cross-section geometry and roughness. Channel cross-section geometry is generally obtained from field surveys and coded into WSPRO as a series of coordinates of horizontal stationing from arbitrary datums and ground elevations referenced to a common datum. Each cross section was given a unique identifier, and the distance (stationing) in feet upstream from the mouth of South Prairie Creek to each cross section was determined. 

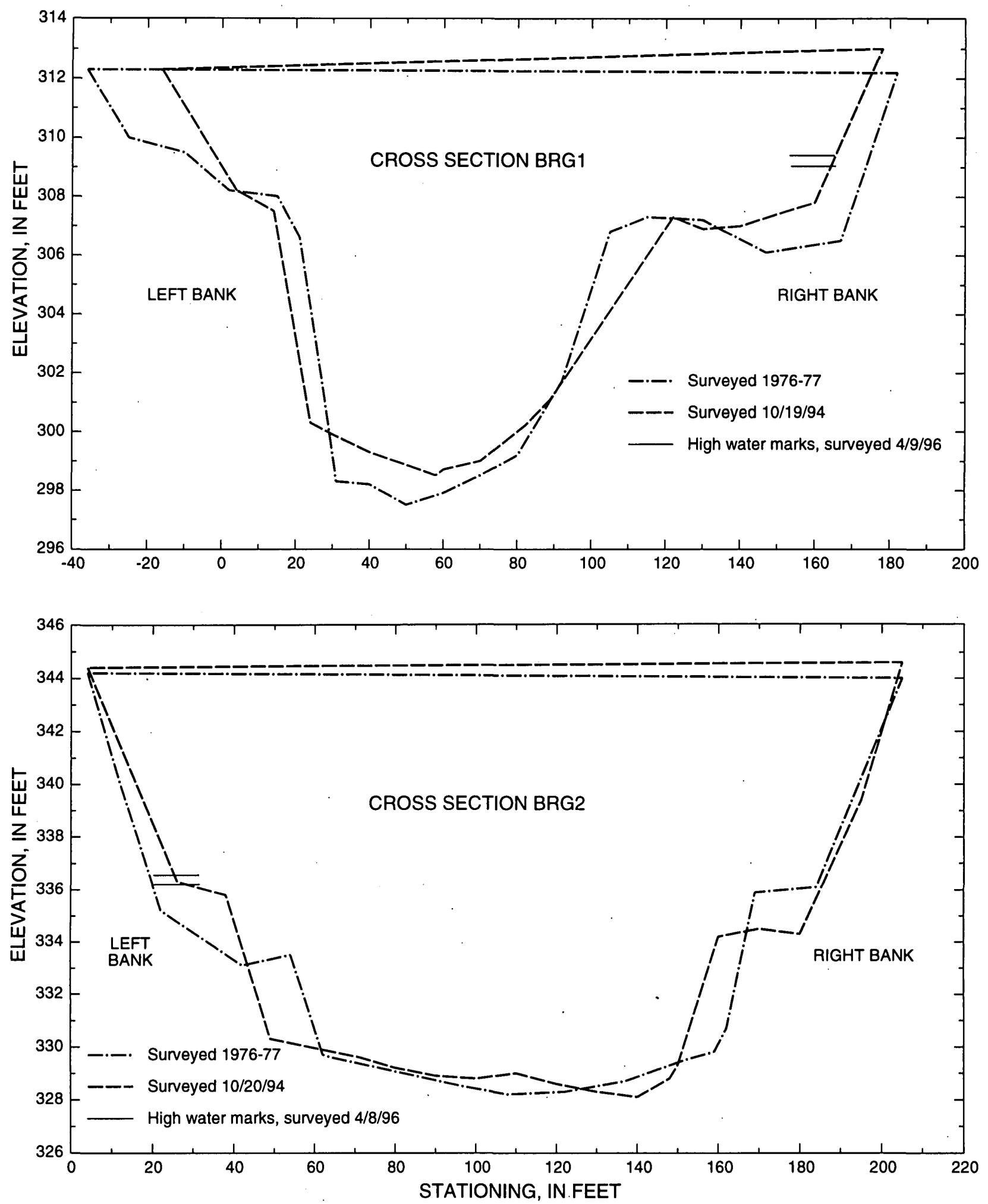

Figure 24. Channel cross sections at the downstream end of Washington State Route 162, Bridges 1 and 2 on South Prairie Creek, Washington. 

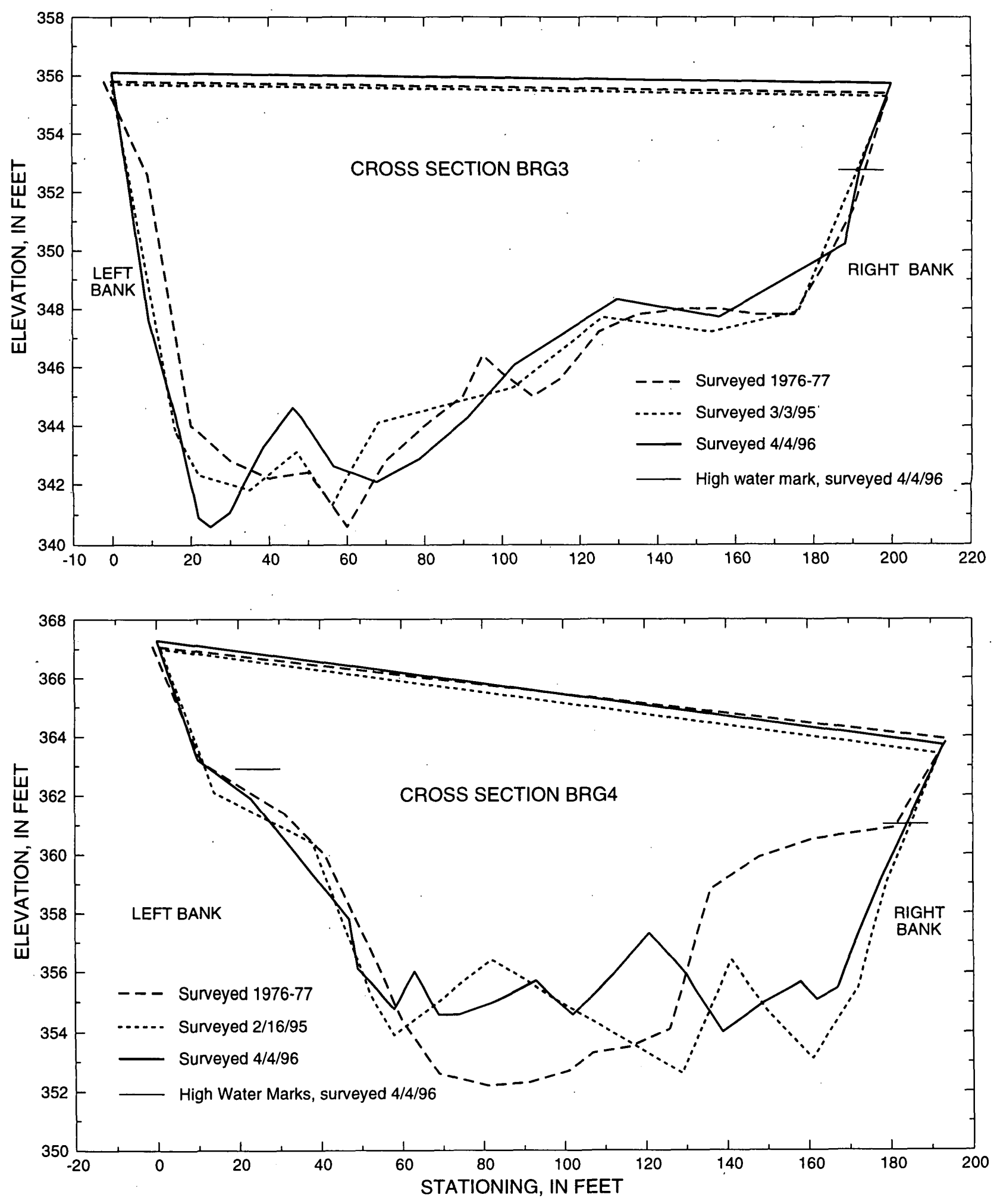

Figure 25. Channel cross sections at the downstream end of Washington State Route 162, Bridges 3 and 4 on South Prairie Creek, Washington. 

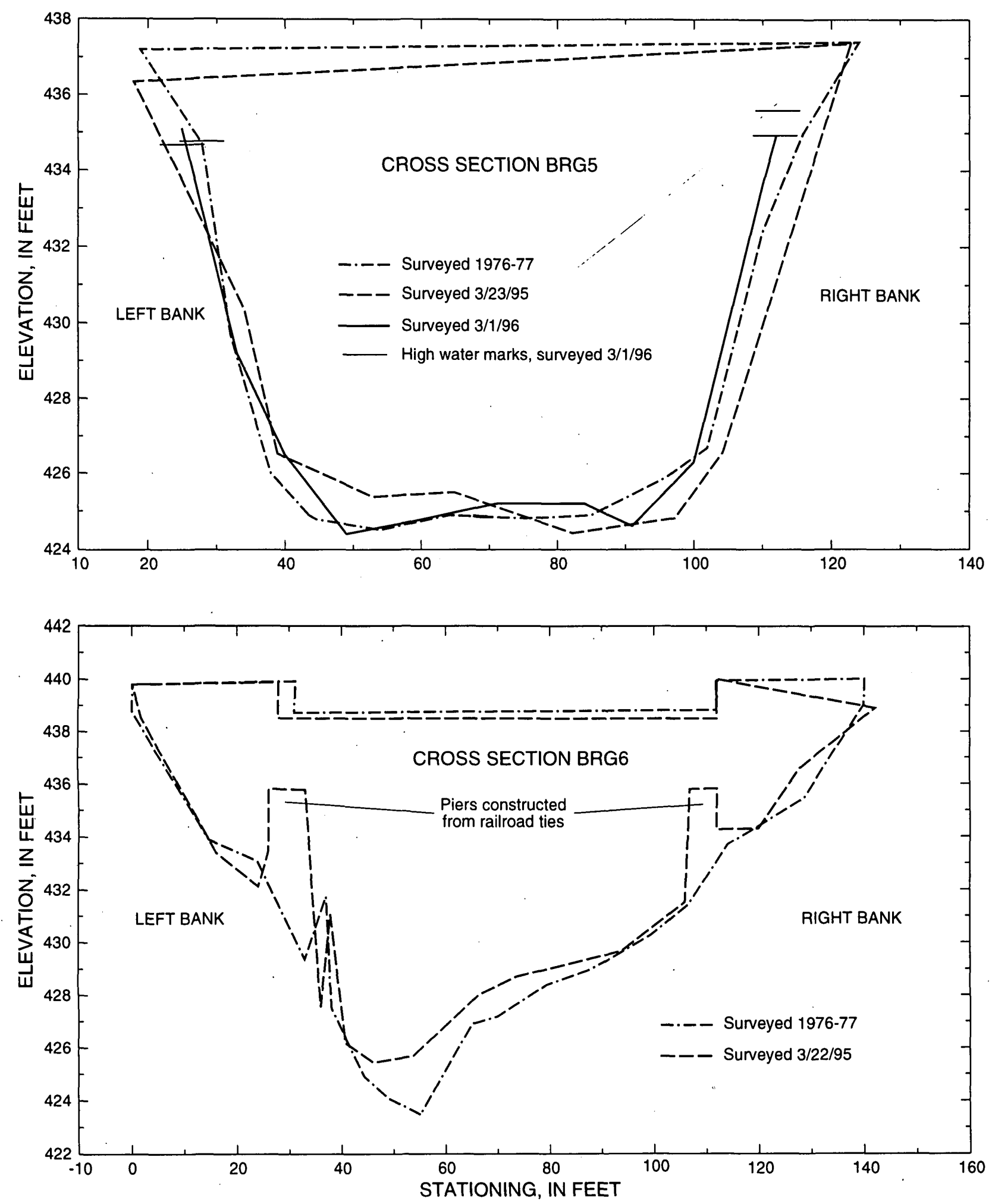

Figure 26. Channel cross sections at the downstream end of Washington State Route 162, Bridge 5, and downstream end of railroad bridge, Bridge 6, on South Prairie Creek, Washington. 

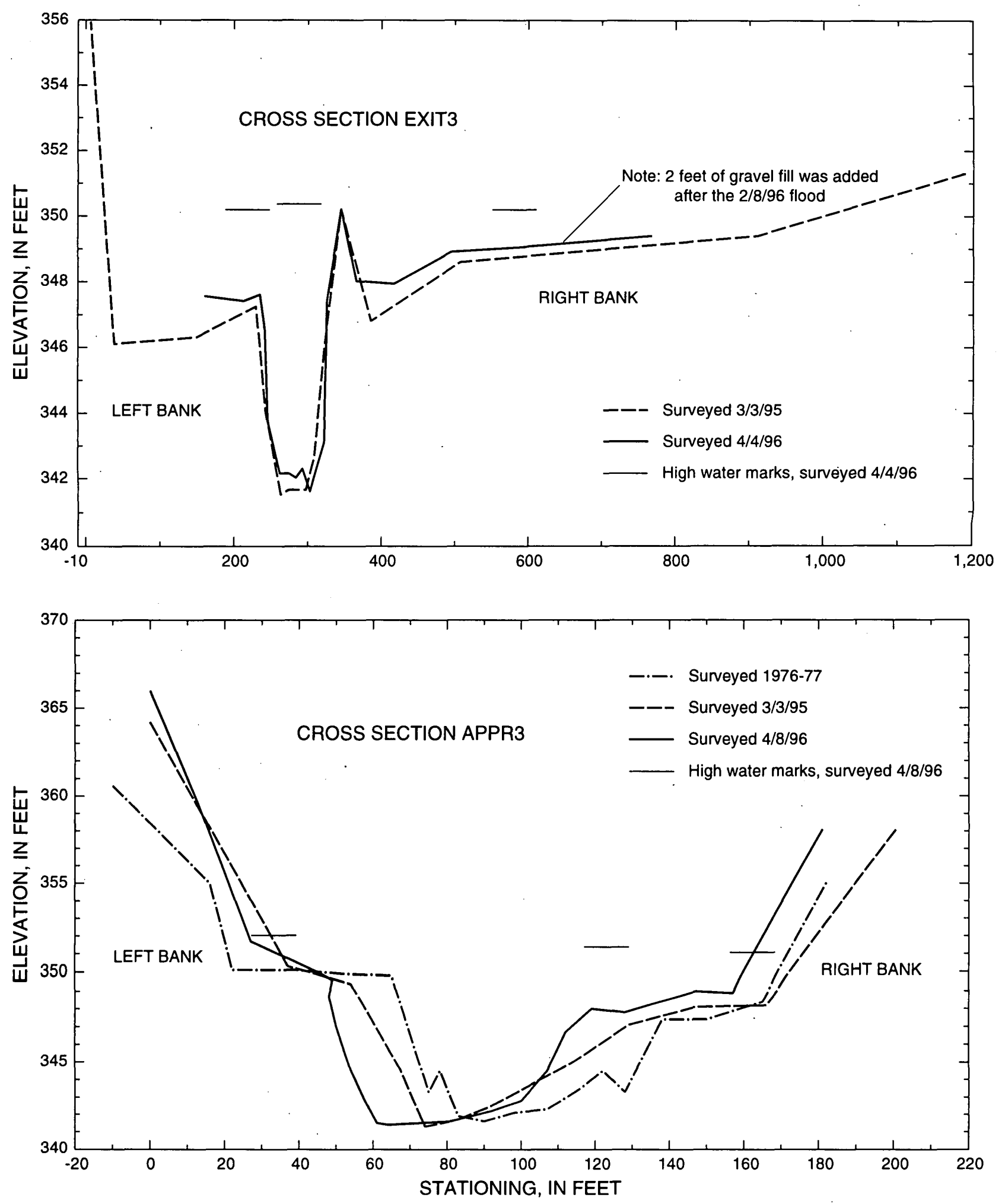

Figure 27. Exit and approach floodplain and channel cross sections to Bridge 3 at Washington State Route 162 over South Prairie Creek, Washington. 

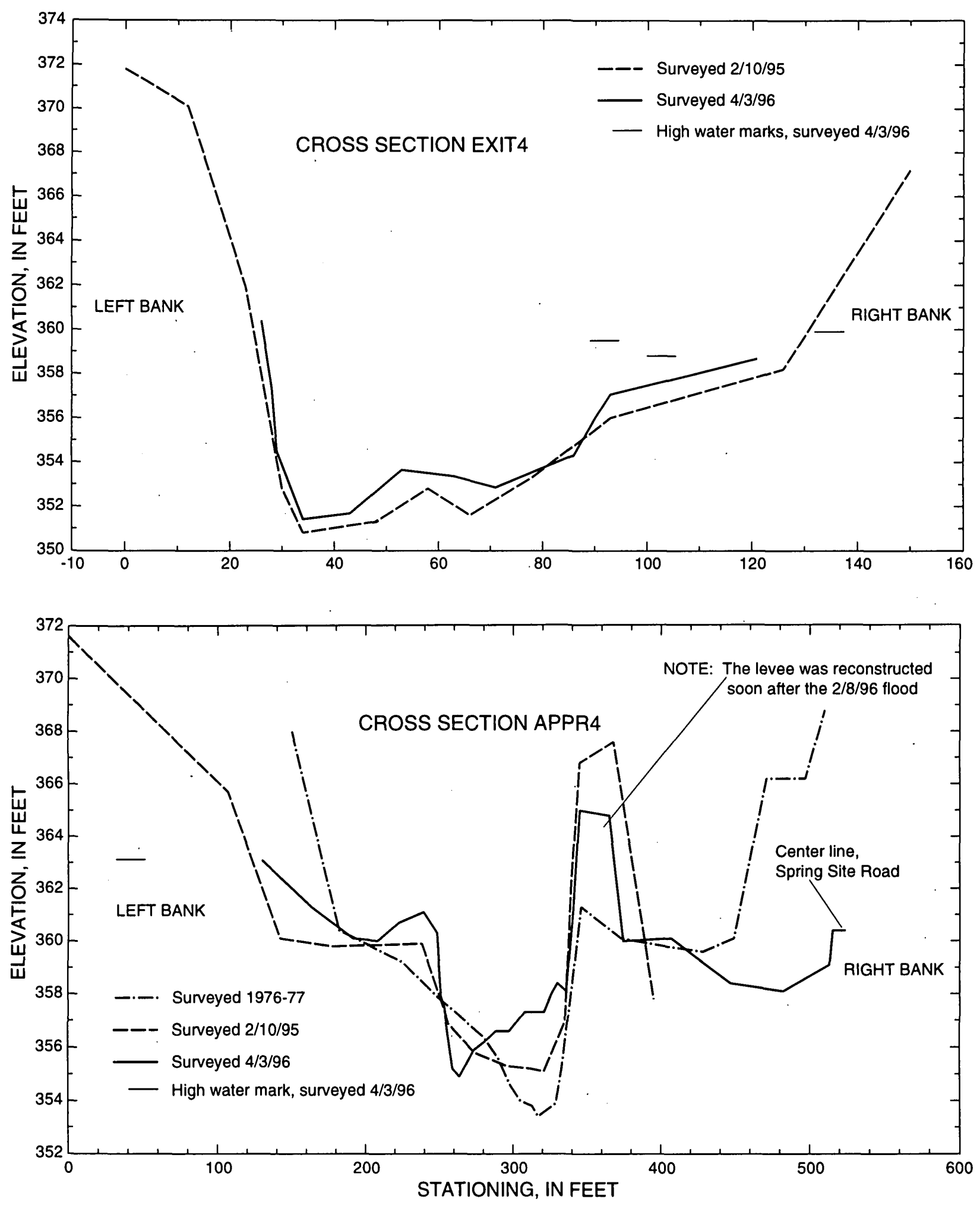

Figure 28. Exit and approach floodplain and channel cross sections to Bridge 4 at Washington State Route 162 over South Prairie Creek, Washington. 

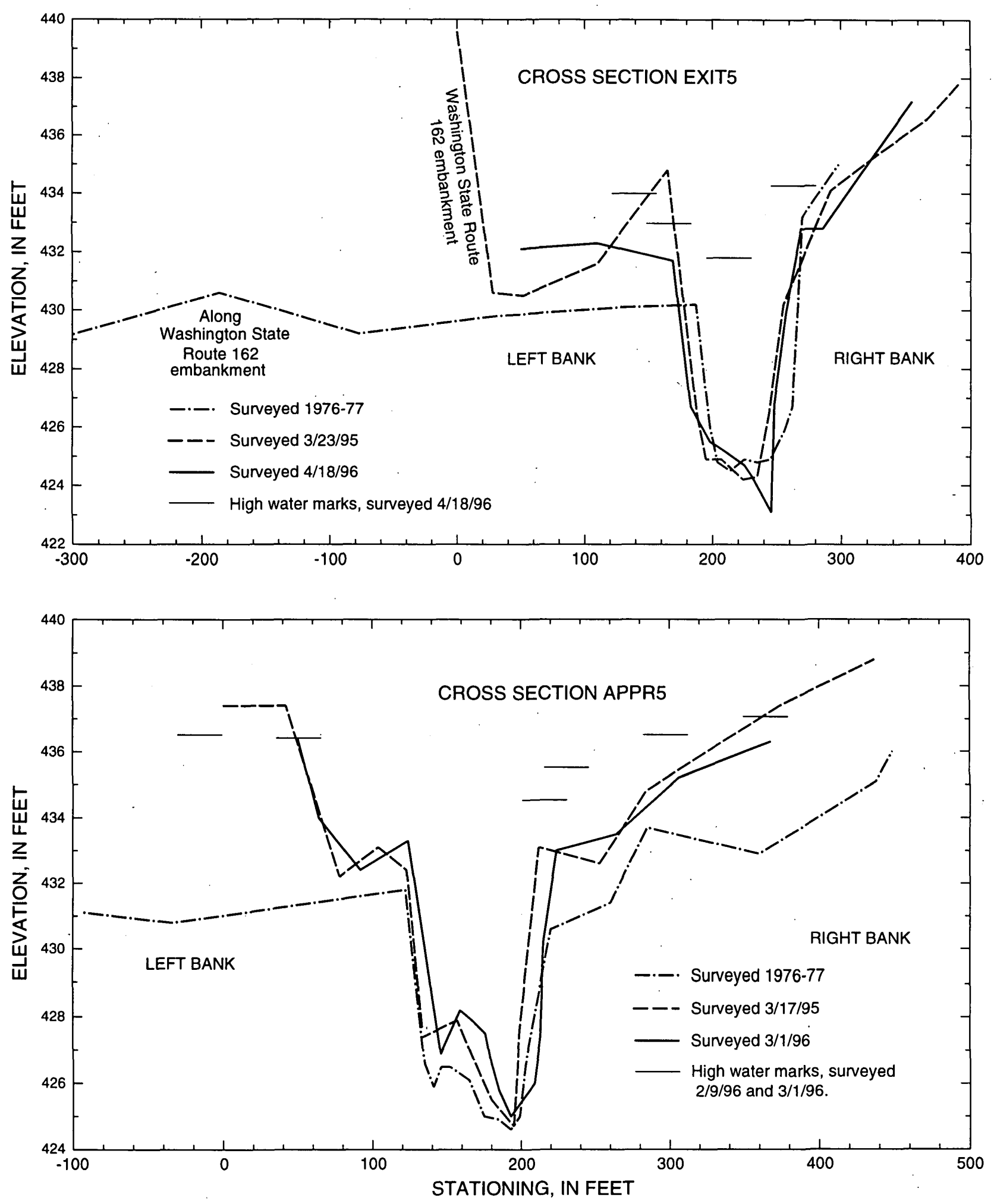

Figure 29. Exit and approach floodplan and channel cross sections to Bridge 5 at Washington State Route 162 over South Prairie Creek, Washington. 

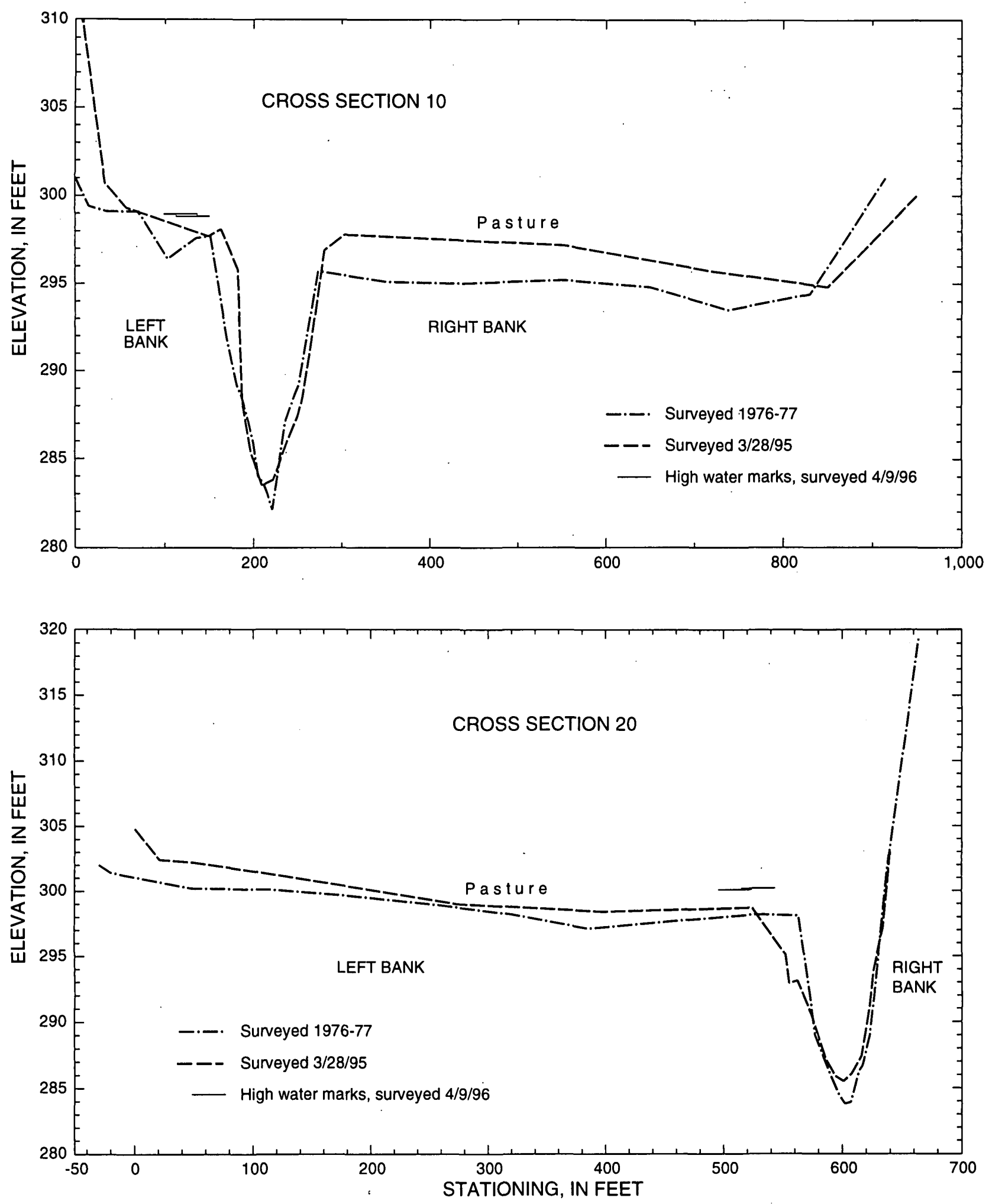

Figure 30. Floodplain and channel cross sections 10 and 20 on South Prairie Creek, Washington. 

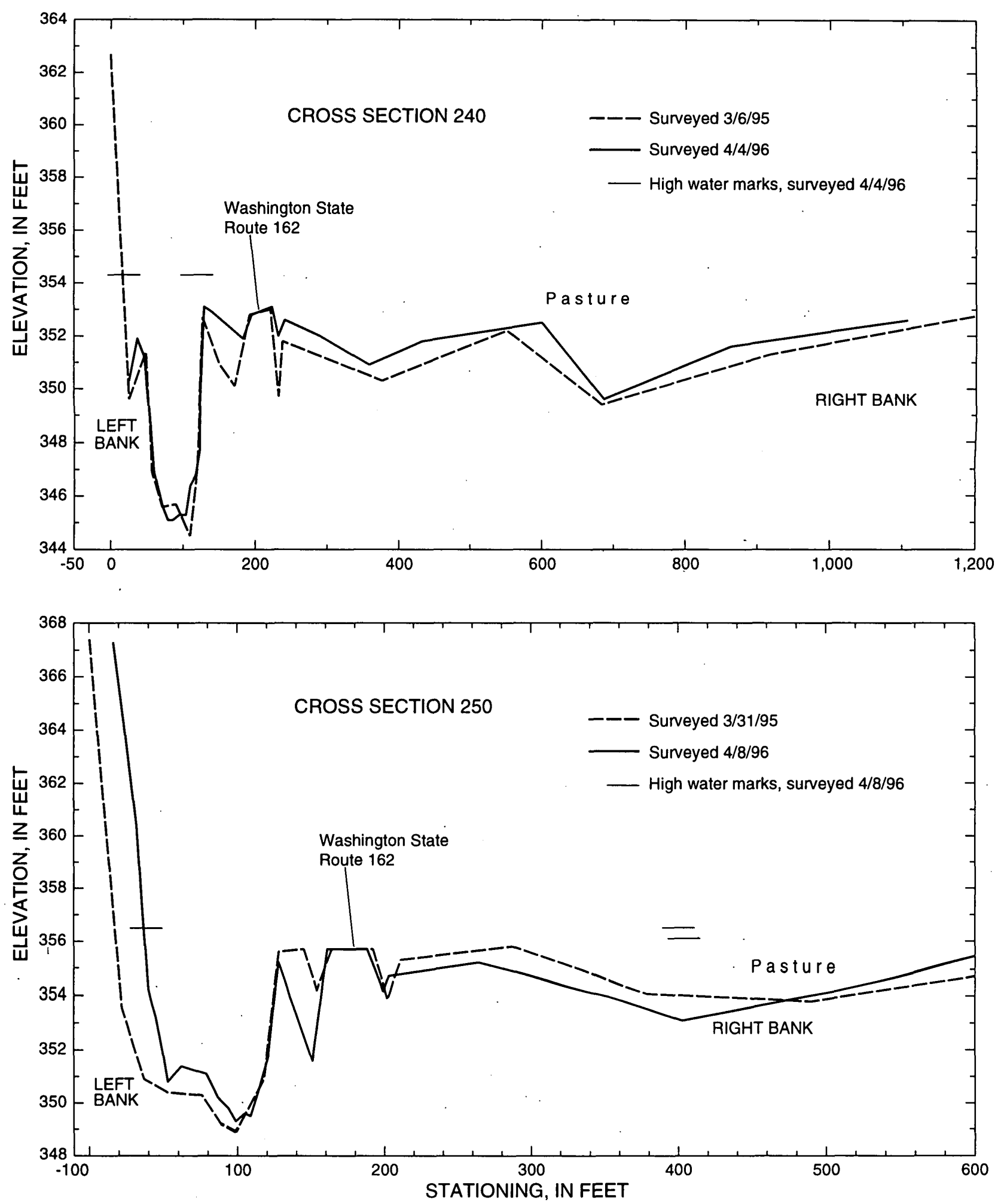

Figure 31. Floodplain and channel cross sections 240 and 250 on South Prairie Creek, Washington. 

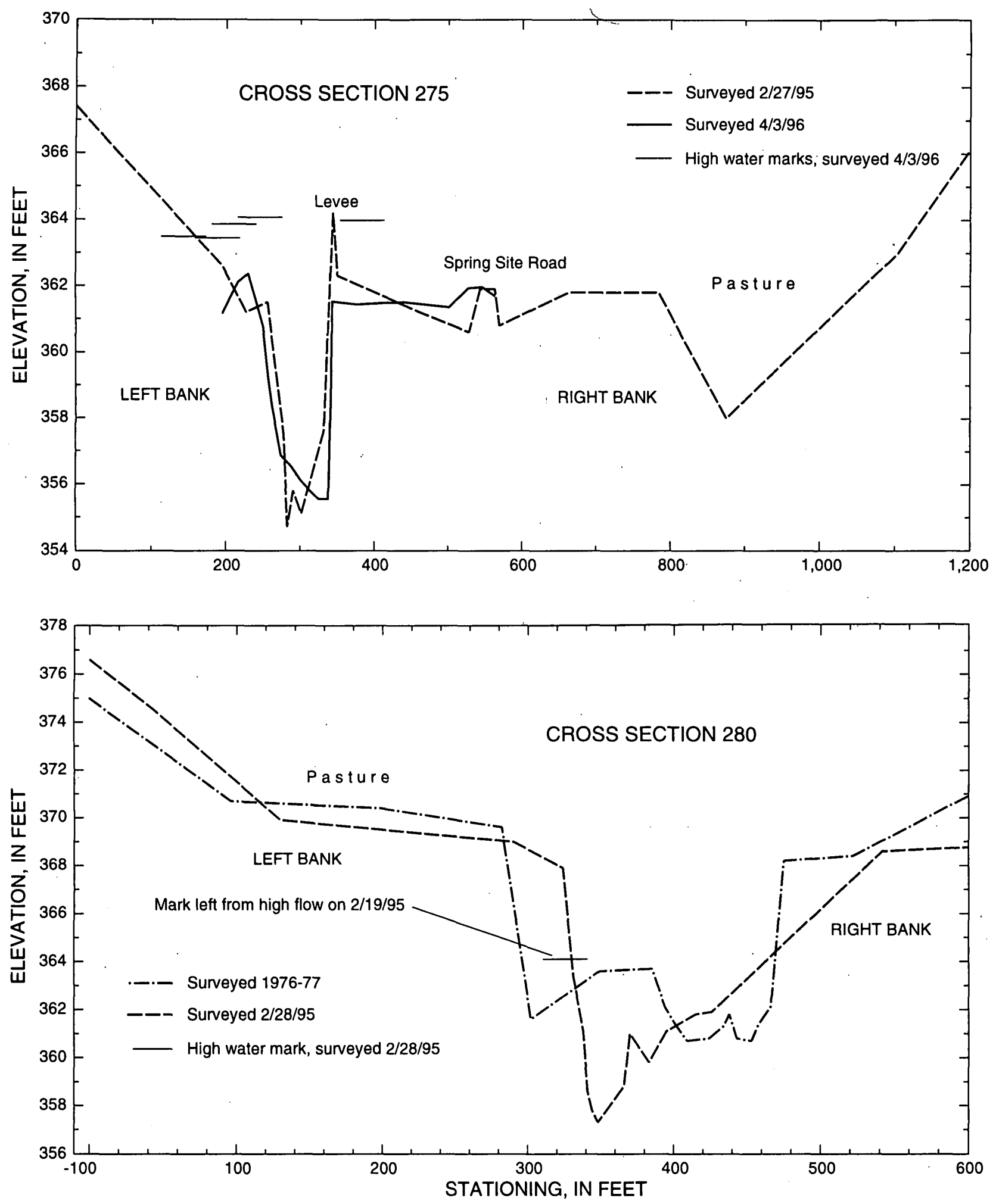

Figure 32. Floodplain and channel cross sections 275 and 280 on South Prairie Creek, Washington. 

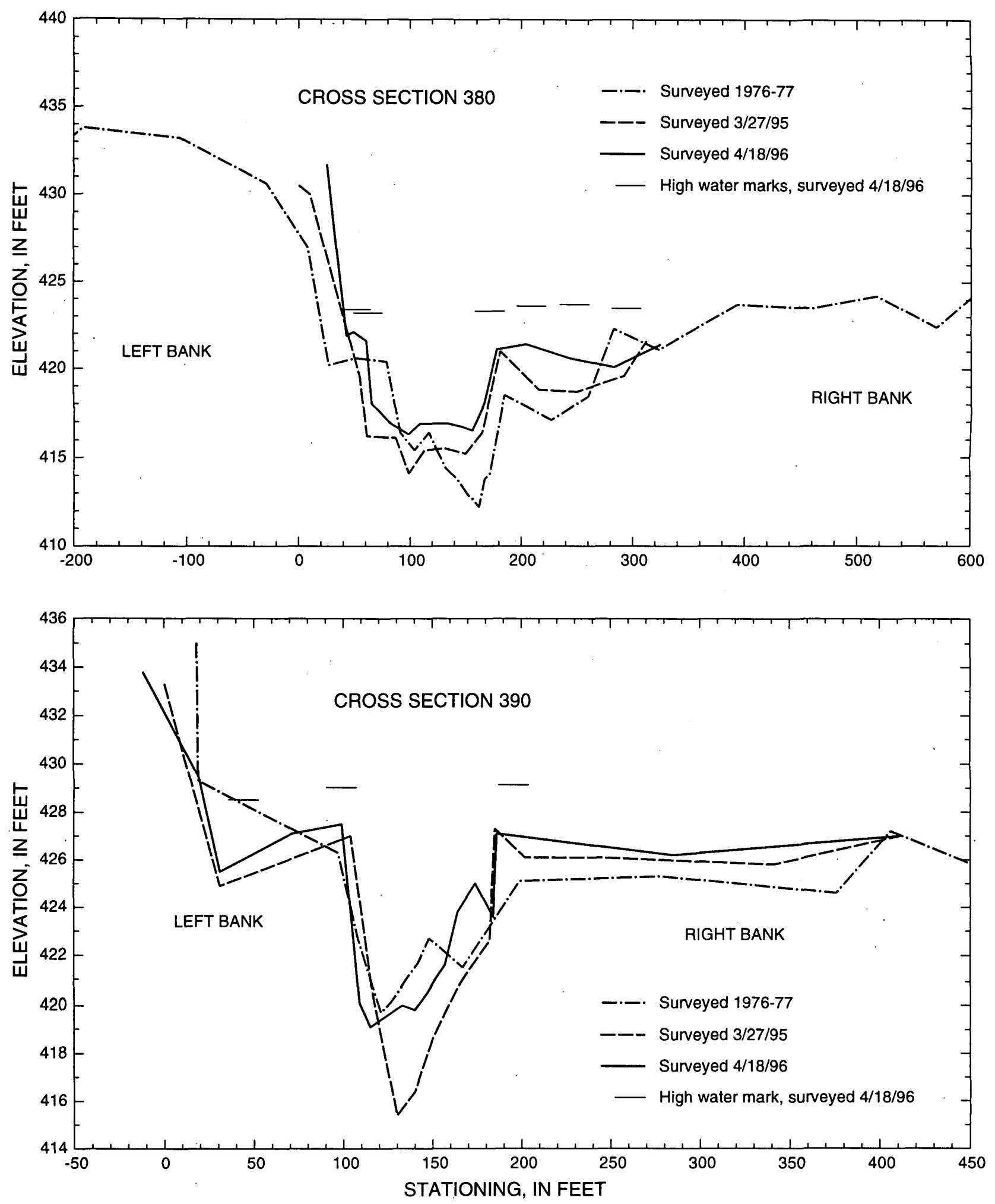

Figure 33. Floodplain and channel cross sections 380 and 390 on South Prairie Creek, Washington. 
At cross-section locations where 1995 or 1996 survey data was not available, the 1976-77 cross-section data were used. The cross-section data at these locations were checked against elevations shown on a series of Walker and Associates maps (1987) titled "South Prairie Creek" and produced from aerial photographs taken on March 28, 1987. These maps provided 1- and 2-foot contours at a scale of 1:600 for most of the floodplain and showed reasonable agreement with the 1976-77 cross-section data, except for cross sections $290,300,310$, and 320 , where the 1976-77 data were consistently 2 to 4 feet higher on the overflow portions of the cross section. The differences may be due to erosion, but it is doubtful that significant erosion occurred because the same farm buildings that are shown on the 1987 maps in this part of the stream reach are visible on the 1976 aerial photos. The reasons for the difference are unknown, but a likely cause is an inaccuracy in the map-making process from the 1976 aerial photos. For these cross sections, the elevations used in WSPRO were taken from the 1987 topographic map, together with the underwater part of the low-water channel obtained from the 1976-77 underwater field surveys of the cross sections.

Cross sections were subdivided at major breaks in channel geometry that maintained a basic channel shape with uniform distribution of flow or conveyance. The usual pattern at a cross section was a main-channel subdivision with two over-bank subdivisions, or if the stream had migrated to one side of the floodplain resulting in a high steep side slope on that side, the usual pattern was a main-channel subdivision with one over-bank subdivision. Channel roughness is defined by Manning's $n$-values, which are somewhat subjective to the field hydrologist who selects them. Benson and Dalrymple (1967, p. 20-24) describe a method often used by the USGS for the determination of $n$-values. For this investigation, the $n$-values were originally selected based on those values used in the FEMA flood insurance study and then subsequently revised based on channel roughness verification model runs (discussed in the next section).

The water-surface profiles were estimated by computations that proceeded in the upstream direction as subcritical flow except for three locations. The program could not find satisfactory subcritical solutions to balance the energy equation for cross sections SSRD, ROAD1 (only for the 10- and 50-year floods), and EX3RT (only for the 10-year flood), and therefore critical water-surface elevations were assumed at these sections. A downstream computation, assuming supercritical flow at cross section SSRD was tried, but the energy equation would still not balance, which indicates that the use of critical depth at this cross section is probably valid. At cross sections ROAD1 and EX3RT at slightly higher discharges, the energy equation balanced with subcritical flows, indicating that determination of critical depth for the lower flows is probably valid.

At cross sections 120, EXIT2, 190, 240, 250, 275, and 390, the upper floodplain on one side of the main channel was either a wide flat area that extended beyond the general floodplain boundary or it contained a depression separated from the main flow of the channel. The original WSPRO runs, which contained these areas coded into the cross sections, showed some unreasonable expansion of flows into these broad expanses or depressions, causing dramatic increases in channel conveyance and often changes in flow regime between subcritical and supercritical flow. These areas are most likely ineffective flow areas that are ponded or not hydraulically active once they fill with water. Based on the particular topography of the cross section and the reach, artificial boundaries were coded into WSPRO to cut off flow into these areas. The model was then rerun to compute water-surface elevations at these cross sections.

A listing of the cross sections and their stationing (distance upstream from above the mouth of South Prairie Creek) is shown in table 9. The table also indicates the years in which the cross-section data were surveyed and the letter identifiers and stationing used in the flood insurance study.

The final WSPRO input and output files are archived on the USGS Washington District computer in Tacoma, Wash.

\section{Estimating Water-surface Profiles at Bridges}

WSPRO requires a minimum of four cross sections at bridge sites to make the necessary water-profile computations for the different types of flow classes that may exist through or around a bridge opening. These include the bridge opening, the approach, the exit, and a full-valley cross section located at the same stream stationing as the bridge cross section (identified in the WSPRO input as FLV\#). The full valley cross sections were defined automatically in WSPRO by propagating the shape of the exit cross section upstream to the bridge using the valley slope to project the elevations, except for FLV4, which used actual field-survey data to define the cross section. 
Table 9. Cross-section identifiers, stationing upstream of the mouth, and year of field survey for cross-section data for South Prairie Creek, Washington

[--, no corresponding data; FEMA, Federal Emergency Management Agency]

\begin{tabular}{|c|c|c|c|c|}
\hline $\begin{array}{l}\text { Cross section } \\
\text { identifier }^{1}\end{array}$ & $\begin{array}{l}\text { Stationing } \\
\text { upstream } \\
\text { of mouth } \\
\text { (feet) }\end{array}$ & $\begin{array}{l}\text { Year } \\
\text { of } \\
\text { survey }\end{array}$ & $\begin{array}{l}\text { FEMA } \\
\text { identifier }^{2}\end{array}$ & $\begin{array}{l}\text { Stationing } \\
\text { upstream } \\
\text { of mouth } \\
\text { (feet) }\end{array}$ \\
\hline 10 & 1,300 & 1995 & A & 1,300 \\
\hline 20 & 2,080 & 1995 & B & 2,080 \\
\hline 30 & 2,740 & $1976-77$ & $\mathrm{C}$ & 2,740 \\
\hline 40 & 3,500 & $1976-77$ & $\mathrm{D}$ & 3,500 \\
\hline 50 & 4,830 & $1976-77$ & $\mathrm{E}$ & 4,830 \\
\hline 60 & 5,570 & $1976-77$ & $\mathrm{~F}$ & 5,570 \\
\hline OVRFL1 & 6,130 & ${ }^{3} 1987$ & - & -- \\
\hline EXIT1 & 6,720 & 1995 & G & 6,780 \\
\hline BRG1 & 6,850 & 1994 & -- & 6,850 \\
\hline APPR 1 & 7,030 & 1995 & -- & 7,040 \\
\hline 85 & 7,090 & ${ }^{3} 1987$ & .. & -- \\
\hline ROAD1 & 7,330 & ${ }^{3} 1987$ & & -- \\
\hline 90 & 7,980 & $1976-77$ & $\mathrm{H}$ & 7,980 \\
\hline 100 & 8,780 & $1976-77$ & I & 8,780 \\
\hline $110^{\circ}$ & 9,590 & $1976-77$ & -- & 9,590 \\
\hline 120 & 10,360 & $1976-77$ & $\mathbf{J}$ & 10,360 \\
\hline 130 & 11,270 & $1976-77$ & -- & 11,270 \\
\hline 140 & 12,080 & $1976-77$ & $\mathrm{~K}$ & 12,080 \\
\hline 150 & 13,040 & $1976-77$ & $\mathrm{~L}$ & 13,040 \\
\hline 160 & 13,820 & $1976-77$ & $\vec{M}$ & 13,820 \\
\hline EXIT2 & 14,500 & 1994 & $\mathrm{~N}$ & 14,520 \\
\hline BRG2 & 14,620 & 1994 & $\therefore$ & 14,620 \\
\hline APPR2 & 14,790 & 1994 & $\mathrm{O}$ & 14,840 \\
\hline 190 & 15,580 & $1976-77$ & $\mathrm{P}$ & 15,580 \\
\hline 200 & 16,430 & $1976-77$ & $\mathrm{Q}$ & 16,430 \\
\hline 210 & 17,110 & $1976-77$ & $\mathrm{R}$ & 17,110 \\
\hline EXIT3 & 17,750 & 1996 & $\mathrm{~S}$ & 17,850 \\
\hline BRG3 & 17,910 & 1996 & -- & 17,910 \\
\hline OVRFL3 & 17,950 & ${ }^{3} 1987$ & -- & -- \\
\hline APPR3 & 18,130 & 1996 & $\mathrm{~T}$ & 18,060 \\
\hline 240 & 18,680 & 1996 & $\mathrm{U}$ & 18,780 \\
\hline 250 & 19,400 & 1996 & V & 19,460 \\
\hline EXIT4 & 19,930 & 1996 & W & 20,020 \\
\hline SSRD & 20,050 & 1996 & -. & -- \\
\hline BRDG4 & 20,080 & 1996 & -- & 20,080 \\
\hline LEVEE & 20,220 & 1996 & -- & -- \\
\hline APPR4 & 20,230 & 1996 & $\mathrm{X}$ & 20,200 \\
\hline 275 & 20,575 & 1996 & -- & -- \\
\hline 280 & 21,020 & 1995 & $\mathrm{Y}$ & 20,960 \\
\hline 290 & 21,740 & ${ }^{3} 1987$ & Z & 21,740 \\
\hline 300 & 22,700 & ${ }^{3} 1987$ & $\mathrm{AA}$ & 22,700 \\
\hline 310 & 23,460 & ${ }^{3} 1987$ & $\mathrm{AB}$ & 23,460 \\
\hline 320 & 24,320 & ${ }^{3} 1987$ & $\mathrm{AC}$ & 24,320 \\
\hline 330 & 25,120 & $1976-77$ & $A D$ & 25,120 \\
\hline 340 & 25,900 & $1976-77$ & $\mathrm{AE}$ & 25,900 \\
\hline 350 & 26,900 & $1976-77$ & $\mathrm{AF}$ & 26,900 \\
\hline 360 & 27,840 & $1976-77$ & $A G$ & 27,840 \\
\hline 370 & 28,670 & $1976-77$ & $\mathrm{AH}$ & 28,670 \\
\hline 380 & 29,400 & 1996 & AI & 29,380 \\
\hline
\end{tabular}


Table 9. Cross-section identifiers, stationing upstream of the mouth; and year of field survey for cross-section data for South Prairie Creek, Washington--Continued

\begin{tabular}{cllcc}
\hline $\begin{array}{l}\text { Cross section } \\
\text { identifier }^{1}\end{array}$ & $\begin{array}{l}\text { Stationing } \\
\text { upstream } \\
\text { of mouth } \\
\text { (feet) }\end{array}$ & $\begin{array}{l}\text { Year } \\
\text { of } \\
\text { survey }\end{array}$ & $\begin{array}{l}\text { FEMA } \\
\text { identifier }^{2}\end{array}$ & $\begin{array}{l}\text { Stationing } \\
\text { upstream } \\
\text { of mouth } \\
\text { (feet) }\end{array}$ \\
\hline 390 & 30,400 & 1996 & AJ,A* & 30,380 \\
EXIT5 & 31,250 & 1996 & $\mathrm{~B}^{*}$ & 31,300 \\
BRG5 & 31,350 & 1996 & -- & 31,350 \\
APPR5 & 31,460 & 1995 & $\mathrm{C}^{*}$ & 31,400 \\
OVRFL5 & 31,500 & 31996,1987 & -- & - \\
EXIT6 & 31,610 & 1995 & $\mathrm{D}^{*}$ & 31,660 \\
BRG6 & 31,690 & 1995 & -- & 31,690 \\
ROAD6 & 31,705 & 1995 & -- & 31,800 \\
APPR6 & 31,840 & 1995 & $\mathrm{E}^{*}$ & 32,510 \\
\hline 440 & 32,250 & 1995 & $\mathrm{~F}^{*}$ & \\
\hline
\end{tabular}

\footnotetext{
${ }^{1}$ This is the identifier used to identify each cross section in the step-backwater model input file used for this investigation. The preceding zeros on the number have been left off.

${ }^{2}$ Cross-section identifiers found in the flood insurance study for Pierce County, Wash., unincorporated areas (FEMA, 1987). Those with an "*" following the cross-section identifiers refer to cross section identifiers found in the flood insurance study for the Town of South Prairie, Pierce County, Wash. (Federal Emergency Management Agency, 1981).

${ }^{3}$ Cross-section data was from a series of maps titled "South Prairie Creek" (Walker and Associates, 1987). In some cases where the low-flow channel information was needed, the underwater portion of the channel cross section not shown on the maps was taken from the under-water field surveys made in 1976-77.
}

All the bridges were coded into WSPRO as type 3 bridges, which are bridges with sloping embankments and sloping spill-through abutments. Data coding for the bridge cross sections included descriptions of the opening geometry, including the embankment slope and elevation, bridge width; cross-sectional area of piers or pilings; elevation of the low chord of the bridge opening; and the angle, if any, of the bridge from being perpendicular to the direction of flow.

At all the bridges, part of the flow at higher discharges goes around the bridge and then rejoins the main channel downstream. At three of the state highway bridges, this was indirectly observed after the February 8, 1996, flood, where debris and high water marks clearly indicated flow around Bridges 1, 3, 4, and 6 and nearly overflowing the left bank at Bridge 5. In the WSPRO program, three different methods were used to simulate this type of flow. At Bridge 6, an extra cross section, ROAD6 (fig. 23), representing the old railroad grade and part of a trailer court on the right side of the main channel, was added to the program input file as a graveled road-grade cross section that passes water as road overflow (see Shearman and others, 1986 , p. 33-36) when the water-surface elevation immediately upstream from the bridge exceeds the minimum road elevation. The program automatically computes the road overflow, subtracts it from the flow through the bridge, and then adds it to the exit section.

At Bridges 1, 3, and 4 during floods, overflow separates from the main channel flow upstream of the approach cross section and rejoins the main channel downstream of the exit cross section. For these bridges, a "flow past islands" method was used (Davidian, 1984, p. 30-32). The two separate channels (three channels in the case of Bridge 1) are defined, and water profiles are estimated with the program for a number of discharges. At the upstream point of separation, the water-surface elevations of the separate flows are plotted until the elevations from two discharges whose sum equals the total discharge are equal or nearly equal. In some cases, the surveyed cross sections were divided at the high points to divide the cross section into two channels; in other cases, extra cross sections were added. 
Several of the bridges required specialized treatment of flood flows or supplementary overflow cross sections. At Bridge 1, cross sections ROAD1 and 85 were developed for the right overflow channel, and OVRFL1 was developed for the left overflow channel from the 1:600 scale South Prairie Creek topographic maps. Ovierflows to the right of Bridge 1 were assumed to separate at cross section 90 and recombine with the main flow at cross section EXIT1, while overflows to the left of Bridge 1 were assumed to separate at cross section APPR1 and recombine with the main flow at cross section 60 .

At Bridge 2 some flow during the 100 - and 500 -year floods was estimated to flow over the highway just upstream of the bridge and flow around the bridge. The water that overflows the highway flows into a flat, backwater expanse of pasture that is assumed to be a hydraulically ineffective flow area. In the model, the cross sections were constricted to confine all the water through the bridge.

At Bridge 3 for the 10-, 50-, 100-, and 500-year floods, the approach elevations suggested that the flow would overtop the road on the left bank just south of the bridge at its intersection with State Route 162. Cross section OVRFL3 (fig. 21) was defined along the crown of the road using the 1:600 scale South Prairie Creek topographic maps, and a road-overflow computation using methods described by Hulsing $(1984$, p.26) was made to determine a stage-overflow rating for the site for stages from 349.0 to 353.0 feet. During a series of trial-and-error model runs to estimate water-surface profiles in the vicinity of Bridge 3, water-surface profiles at the approach section together with the stage-overflow rating (fig. 34) were used to determine the flow over the road. The flow was subtracted from the EXIT3 cross section and then added again to the approach cross section until the total of the flow over OVRFL 3 and through the bridge agreed with the appropriate discharge for the approach cross section for the "flow past islands" procedure (described earlier in this section of the report) that was used simultaneously.

At Bridge 4, cross sections SSRD and LEVEE (fig. 21), which represent the right overflow channel, were field surveyed on November 18, 1996, soon after reconstruction of Spring Site Road and the Spring Site Road levee just upstream of Bridge 4.
The situation at Bridge 5 was similar to that at Bridge 3 , but overflow only occurs for the 500 -year flood. The water-surface elevations on the upstream side of the bridge were higher than a grassy levy forming the left bank at the end of cross sections APPR5 and EXIT6. Cross section OVRFL5 (fig. 23) defines the overflow cross section along the top of the levee and was used to develop a stage-overflow rating for stages from 437.4 to 440 feet using the same methods as those used for OVRFL3 (fig. 21). Any significant water flowing over this levee would flow through the town of South Prairie as shallow flooding over a large area and most likely return to the creek at cross section 300 by flowing down an existing small channel west of town. For the 500-year flood profiles, discharge upstream of cross section 300 was reduced by various amounts, and the water-surface computations were continued to the approach cross section to Bridge 5, at which point the subtracted discharge was added back into the model and the computations continued upstream using the full 500-year flood discharge. The estimated overflow was determined using the computed water-surface elevations at the approach to Bridge 5, and the final profile was selected when the amount of overflow at cross section OVRFL5 equalled the amount of discharge removed at cross section 300.

When water-surface elevations are at or near a low chord elevation of a bridge, as they are at Bridge 5 for the 500-year flood, computed water-surface elevations can be very sensitive to changes in discharge - a small change in discharge may result in a large change in elevation. At discharges of $9,020 \mathrm{ft}^{3} / \mathrm{s}$ and less through Bridge 5, the numerical model uses free-surface-flow computations through the bridge opening to compute water-surface elevations. (Note that the computed water-surface elevations at $8,200 \mathrm{ft}^{3} / \mathrm{s}$ match observed water-surface elevations for the flood of February 8, 1996, reasonably well. See figure 35.) At discharges of $9,030 \mathrm{ft}^{3} / \mathrm{s}$ and higher, the numerical model uses orifice-flow computations to compute water-surface elevations. (Note that the computed water-surface elevation at the approach cross section to Bridge 5 at $9,030 \mathrm{ft}^{3} / \mathrm{s}$ is 2.1 feet higher than at $9,020 \mathrm{ft}^{3} / \mathrm{s}$. See figure 35.). Because of this discontinuity and the uncertainty of the proper flow computation to use, two separate sets of model runs were used through Bridge 5 to estimate water-surface elevations for the 500-year flood, one using orifice-flow computations and one using free-surface-flow computations (fig. 35). 

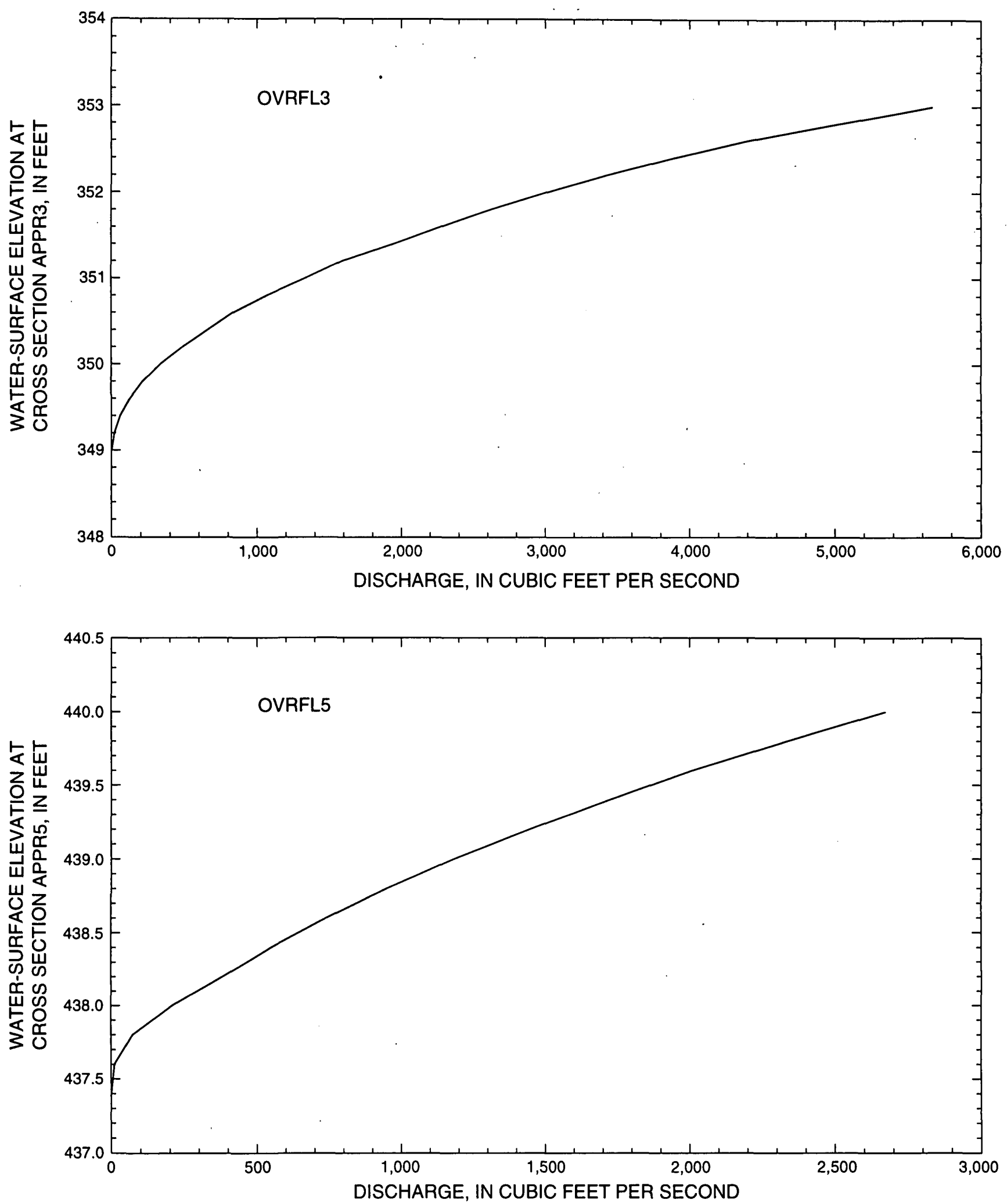

Figure 34. Overflow rating curves for cross sections OVRFL3 and OVRFL5, South Prairie Creek, Washington. 


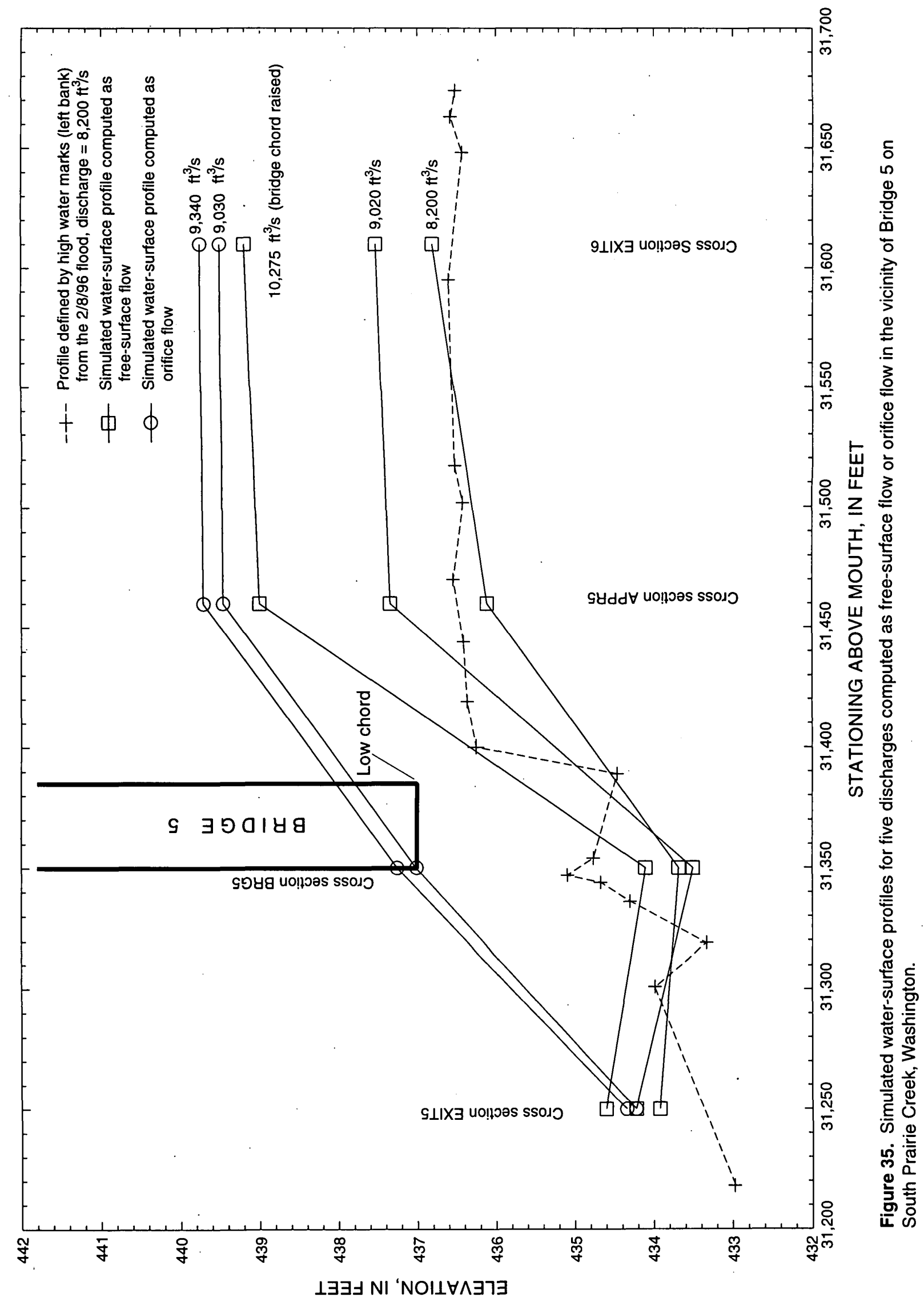


The highest resulting elevations from these two model runs were used for the flood inundation maps. The computation using orifice-flow computations resulted in a discharge of $9,340 \mathrm{ft}^{3} / \mathrm{s}$ going through Bridge 5 and $2,160 \mathrm{ft}^{3} \mathrm{~s}$ flowing over cross section OVRFL5. Free-surface flow through the bridge was made by raising the elevation of the low chord in the model input, which resulted in a combination of $10,275 \mathrm{ft}^{3} / \mathrm{s}$ going through the bridge and $1,225 \mathrm{ft}^{3} / \mathrm{s}$ flowing over cross section OVRFL5. The computed Froude number at the BRDG5 cross section was 1.15 , indicating that flow was at or near critical flow.

Inundation maps were prepared from computations using $10,275 \mathrm{ft}^{3} / \mathrm{s}$ and free-surface flow for water-surface elevations downstream from Bridge 5 and $9,340 \mathrm{ft}^{3} / \mathrm{s}$ and orifice flow for water-surface elevations upstream from Bridge 5. Upstream, water-surface elevations at EXIT6 for the 500-year flood were above the low-chord elevation for Bridge 6 , and, therefore, the numerical model used its submerged-orifice computation to estimate water-surface elevations.

\section{Downstream Boundary Conditions}

It should be noted that any step-backwater analysis begins with an assumed water-surface elevation at the farthest downstream cross-section; consequently, the first few cross-section elevations may differ from the true elevations. However, the water-surface profiles of different starting elevations will converge as they approach the normal-depth profile (normal depth is the constant depth in a long channel of uniform hydraulic characteristics for a steady discharge). Starting water-surface elevations for each discharge were computed by WSPRO by slope-conveyance computations at the farthest downstream cross section (10) assuming an energy gradient of 0.0035 . The energy gradient of 0.0035 was the approximate energy gradient determined from the $n$-verification runs for the main channel. These starting elevations produced profiles that made the transition smoothly into the profile upstream of the convergence point at cross section 30, 2,740 feet above the mouth (fig. 36). Figure 36 shows profiles for critical-depth starting elevations that cross over the other profiles. This is not physically possible when all the profiles are for subcritical flows. It is a computational problem with the model that could probably be rectified with additional cross-sectional information between cross sections 10 and 30 . It should also be noted that the Carbon River may be flooding at the same time as South Prairie Creek, which would cause backwater effects on South
Prairie Creek for the first several cross sections and raise the water-surface elevations above where they would have been if the Carbon River flow was low. This was evident during the February 8, 1996, flood. High water marks at cross sections 10 and 20 during the February 19, 1995, flood showed a water-surface gradient of 0.003 , while during the February 8, 1996, flood (a flood with over three times the discharge) high water marks showed a gradient of 0.0016-a situation where backwater from the Carbon River flooding was influencing the water-surface elevations near the mouth of South Prairie Creek. For those reasons, the flood inundation maps and water-surface profiles may not be reliable downstream of cross section 30 at station 2,740 feet above the mouth.

\section{Channel Roughness Verification}

The $n$-values used in the flood insurance study to describe the channel roughness were adjusted as needed in an $n$-verification analysis based on high water marks that were surveyed after two peak flows and a series of trial-and-error WSPRO runs.

The first set of high water marks was left from a relatively small peak flow that occurred on February 19, $1995,\left(2,680 \mathrm{ft}^{3} / \mathrm{s}\right.$ at the USGS-operated stream gage South Prairie Creek at South Prairie. These high water marks, which were surveyed at the same time the 1995 channel cross sections were surveyed, were all contained in the main channel near the top of the banks. These marks were compared with simulated water-surface profiles using the 1995 cross-section data and various $n$-values for the main channel. Main channel roughness values determined in this way were generally 0.002 to 0.003 lower than those used in the flood insurance study. Some notable exceptions were an increase in the $n$-value from 0.045 to 0.050 at cross section 280 and decreases from 0.045 to 0.036 at Bridge 5 and 6 , from 0.043 to 0.036 at APPR5 and EXIT6, and from 0.045 to 0.040 at APPR6 and 440 .

The second set of high water marks, mostly surveyed during the period of March 3-18, 1996, were left from the February 8, 1996, flood, which had an estimated peak flow of $8,200 \mathrm{ft}^{3} / \mathrm{s}$ at the gage site. This flood overtopped the main channel at many locations, and, therefore, it provided data to verify the $n$-values for the overbank portions of the cross sections. Overbank $n$-values were increased by 0.005 to 0.020 over the original values from the flood- 

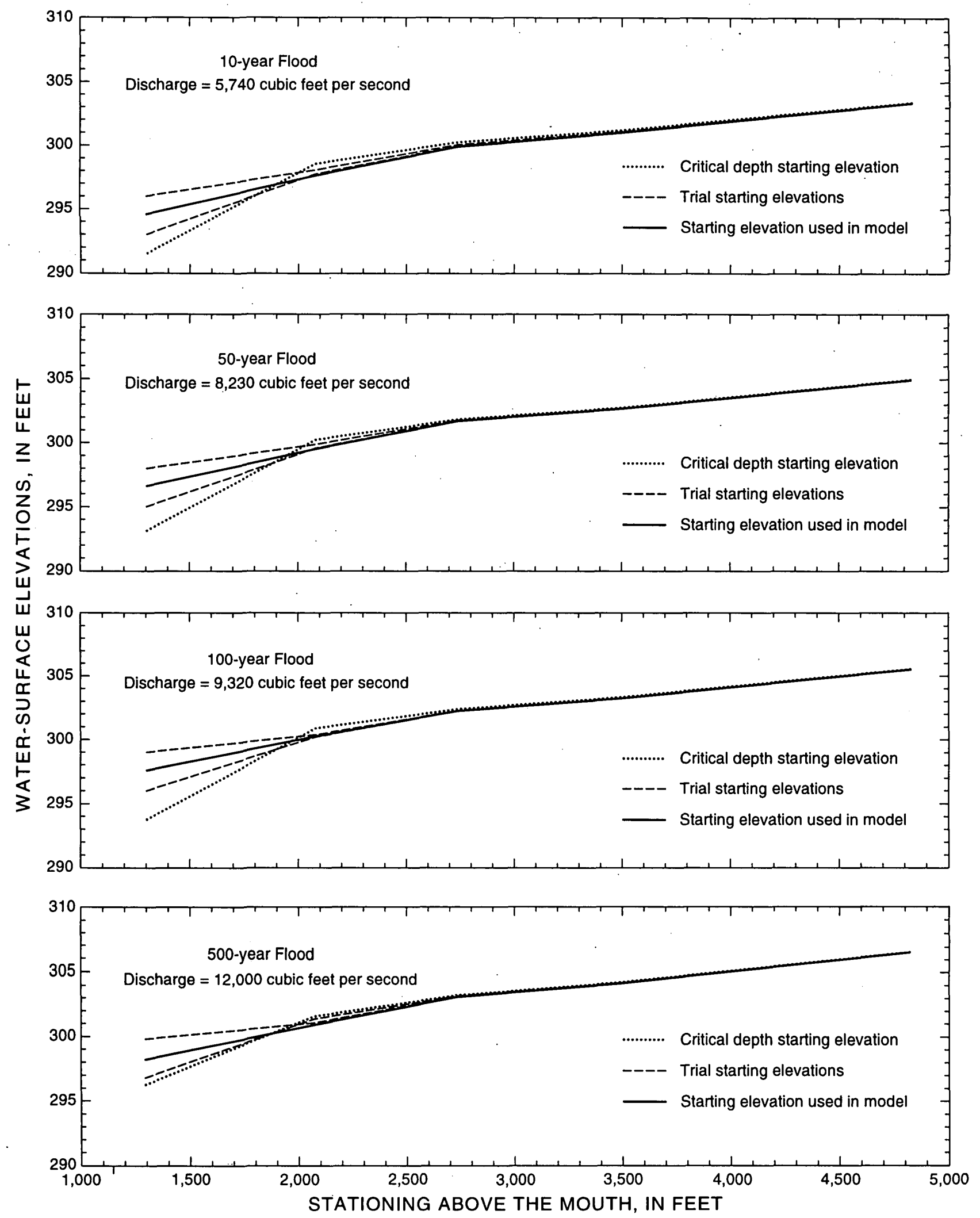

Figure 36. Beginning water-surface profiles from cross sections 10 to 50 for discharges for the 10-,50-, 100-, and 500- year floods on South Prairie Creek, Washington. 
insurance study for the cross sections from the mouth to EXIT3. The overbank $n$-values for cross sections upstream of EXIT3 were all left the same as those used in the flood insurance study, except those at sections 240 and 250 , which were increased by 0.002 , and that for section 380 , which was increased by 0.020 . The surveyed high water marks and estimated water-surface elevations from the $n$-verification runs are shown below for those cross sections where high water marks were obtained (table 10).

The differences between the simulated water-surface profile and the observed high water marks in the final model run sometimes required a compromise between positive and negative errors at nearby cross sections. For example, the largest error is a -1.86-foot error at the SSRD cross section for the February 1996 flood, but near that cross section at BRDG4 the simulated water-surface elevation falls within the range of observed high water marks, and at the exit and approach cross sections, the error is +1.15 (largest positive error) and +0.99 feet, respectively. Two-thirds of the simulated water-surface elevations are within 0.35 feet of the observed high water marks for both floods. (If more than one high water mark was found at a particular cross section, no difference was computed if the simulated value was within the range of values; outside the range, the highest high-water-mark elevation was used to compute the difference.) Matching the simulated profile to the observed high water marks would require unreasonable roughness coefficients that would change dramatically from one cross section to another; instead the errors were averaged by conservatively adjusting the roughness coefficients from one cross section to another.

\section{Simulated Area Inundated by Floods}

Table 11 and figures 37 to 40 show the simulated water-surface elevations for discharges corresponding to the 10-, 50-, 100-, and 500-year floods. The areas of inundation for the 100- and 500-year floods are shown on figures 41 to 45 . Areas were classified as "shallow flooding" where the surface-water profiles showed that the flood would breach valley sides and spill into areas where detailed cross-section information was not available. The area of shallow flooding was estimated, but the depth of flow is unknown.

The results of the step-backwater analysis show the 500-year flood flowing around all the bridges in the study area and overtopping the grassy levee between Bridge 5 and Bridge 6 at cross section OVRFL5 (fig. 34), with a discharge ranging from $1,200 \mathrm{ft}^{3} / \mathrm{s}$, assuming free flow through Bridge 5 , or $2,200 \mathrm{ft}^{3} / \mathrm{s}$, assuming orifice flow through Bridge 5, and an overflow depth of from 1.7 to 2.3 feet. The water is assumed to follow an existing unnamed tributary to South Prairie Creek and re-enter the main channel 1.5 miles downstream at cross section 300 near the mouth of the tributary. Between cross sections ORVFL5 and 300 is the town of South Prairie where the floodwaters would most likely spread out over a wide area as shallow flooding. The extent of the flooding is unknown and would require topographic surveys and further hydraulic analysis beyond the scope of this project.

Along the old railroad grade on the left side of the flood plain between cross sections 40 and 90 (fig. 41) for the 500-year flood and cross sections 50 and 90 for the 100-year flood (fig. 41), the profiles slightly exceed the height of the grade, thus allowing some of the water to spill over. It appears that the water would flow along the outside of the railroad grade and return to the Carbon River near the mouth of South Prairie Creek. Detailed topographic information is not available for this area. It was assumed that the amount of water would be only a small percentage of the total flow; therefore, no hydraulic analysis of the overflow was done, but where detailed topographic information is available, the area is shown as shallow flooding (fig. 41).

The area in the vicinity of Spring Site Road and the main channel of South Prairie (fig. 45) just upstream of the State Route 162 bridge (Bridge 4 in this report) is subject to repeated overtopping of the banks of the main channel by floods and repeated flood damage. The levee was breached by flood waters on February 8, 1996, eroding the levee and a large channel through Spring Site Road. The levee was quickly repaired soon after the flood, and further repairs continued through spring. A supplementary field survey was conducted on November 11, 1996, to measure the most current elevations along the top of the levee and along Spring Site Road (cross sections SSRD and LEVEE, fig. 45). Figure 45 shows the elevations that were surveyed and the area of inundation for the 100- and 500-year floods determined from estimated water-surface elevations, the field-surveyed elevations, and the contour lines shown on the 1:600-scaled South Prairie Creek maps. Even the 10-year flood will easily overtop the banks upstream of Bridge 4 (cross section 275) and flow over Spring Site Road and around the bridge. The 10-year flood is also expected to flow around Bridges 1 and 3. 
Table 10. Elevations of high water marks surveyed near indicated cross sections and water-surface elevations from $n$-verification step-backwater runs for two peak flows on South Prairie Creek, Washington

$[--$, no data $]$

\begin{tabular}{|c|c|c|c|c|}
\hline \multirow[b]{2}{*}{$\begin{array}{l}\text { Cross section } \\
\text { identifier }\end{array}$} & \multicolumn{2}{|c|}{$\begin{array}{l}\text { Peak water-surface elevation } \\
\text { February } 19,1995 \text {, Flood }\end{array}$} & \multicolumn{2}{|c|}{$\begin{array}{l}\text { Peak water-surface elevation } \\
\text { February } 8,1996, \text { Flood }^{1}\end{array}$} \\
\hline & $\begin{array}{l}\text { Observed } \\
(\text { feet })^{2}\end{array}$ & $\begin{array}{l}\text { Simulated } \\
\text { (feet) }\end{array}$ & $\begin{array}{l}\text { Observed } \\
(\text { feet })^{2}\end{array}$ & $\begin{array}{l}\text { Simulated } \\
\text { (feet) }\end{array}$ \\
\hline 10 & 291.66 & 291.60 & $298.94,298.83$ & 298.94 \\
\hline 20 & $293.93,294.08$ & 294.09 & $300.17,300.07$ & 300.16 \\
\hline EXIT1 & -- & 305.58 & 309.69 & 309.48 \\
\hline BRG1 & 307.75 & 305.91 & $309.40,309.04$ & 309.53 \\
\hline APPR1 & - & 306.50 & $310.50,310.03$ & 310.13 \\
\hline 85 & - & -- & 310.99 & 310.90 \\
\hline ROAD1 & - & -- & 312.27 & 312.18 \\
\hline 90 & -- & 309.28 & 312.37 & 312.60 \\
\hline BRG2 & -- & 334.23 & 336.55 & 336.53 \\
\hline APPR2 & -- & 334.63 & $339.05-339.90$ & 339.15 \\
\hline EX3RT & -- & -- & 350.18 & 350.53 \\
\hline EX3LT & -- & -- & $350.36,350.19$ & 348.88 \\
\hline BRG3 & -- & 348.27 & 352.76 & 351.08 \\
\hline APPR3 & 348.72 & 349.16 & $351.08-352.05$ & 351.85 \\
\hline 240 & $349.18-351.42$ & 351.46 & $354.27-354.54$ & 354.45 \\
\hline 250 & $354.06,353.74$ & 354.13 & $356.14-356.54$ & 357.06 \\
\hline SSRD & -- & -- & 364.06 & 362.20 \\
\hline EXIT4 & -- & 357.65 & $358.78,359.93$ & 361.08 \\
\hline BRDG4 & -- & 359.07 & $360.99,362.93$ & 362.60 \\
\hline APPR4 & -- & 359.88 & 363.08 & 364.07 \\
\hline 275 & $361.32,361.54$ & 362.05 & $363.45-364.06$ & 364.47 \\
\hline 280 & 364.10 & 363.73 & -- & 366.44 \\
\hline 380 & 419.05 & 419.17 & $423.24-423.69$ & 423.40 \\
\hline 390 & -- & 425.04 & $427.79-429.14$ & 429.71 \\
\hline EXIT5 & 430.18 & 430.14 & $432.98-434.61$ & 433.92 \\
\hline BRG5 & 430.36 & 431.23 & $434.46-435.59$ & 433.68 \\
\hline APPR5 & 431.62 & 431.53 & $434.54-437.06$ & 436.11 \\
\hline EXIT6 & $432.16,432.26$ & 432.46 & $436.08-436.60$ & 436.81 \\
\hline BRG6 & $431.71-432.02$ & 432.34 & 436.52 (gage reading) & 436.12 \\
\hline APPR6 & $433.43-433.63$ & 434.55 & 438.55 & 439.20 \\
\hline 440 & $435.82-436.46$ & 436.67 & $439.49-440.82$ & 440.28 \\
\hline
\end{tabular}

${ }^{1}$ Four percent of the flow was added to the discharge recorded at the South Prairie stream gage in the step-backwater model for cross sections 10 through 275 .

${ }^{2}$ If one or two high water marks were found for a particular cross section, they are both shown separated by a comma (for example, $354.06,353.74$ ). If more than two high water marks were found for a particular cross section, then only the range in high water marks is shown, with the values separated by a hyphen (for example, 349.18-351.42). 


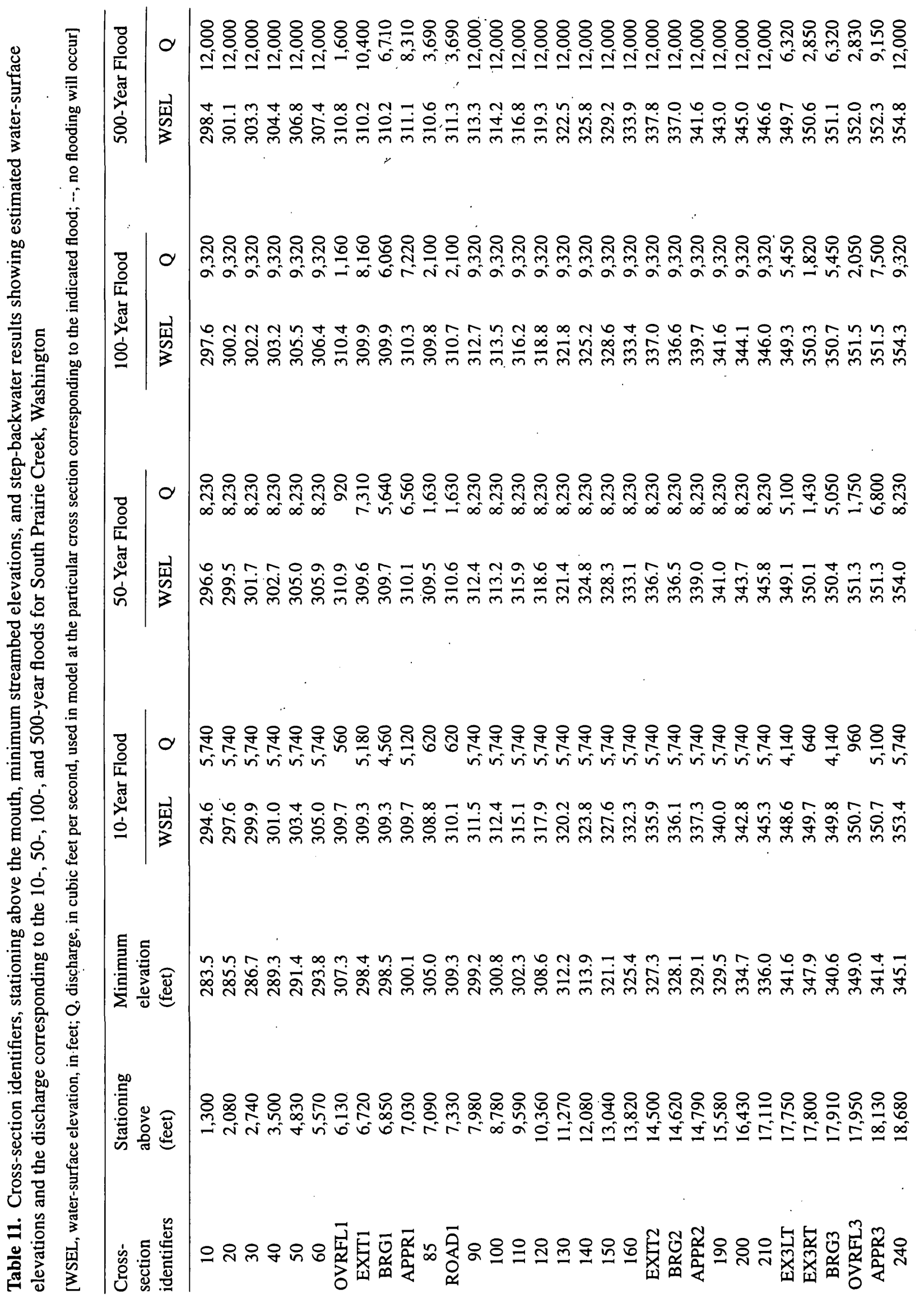




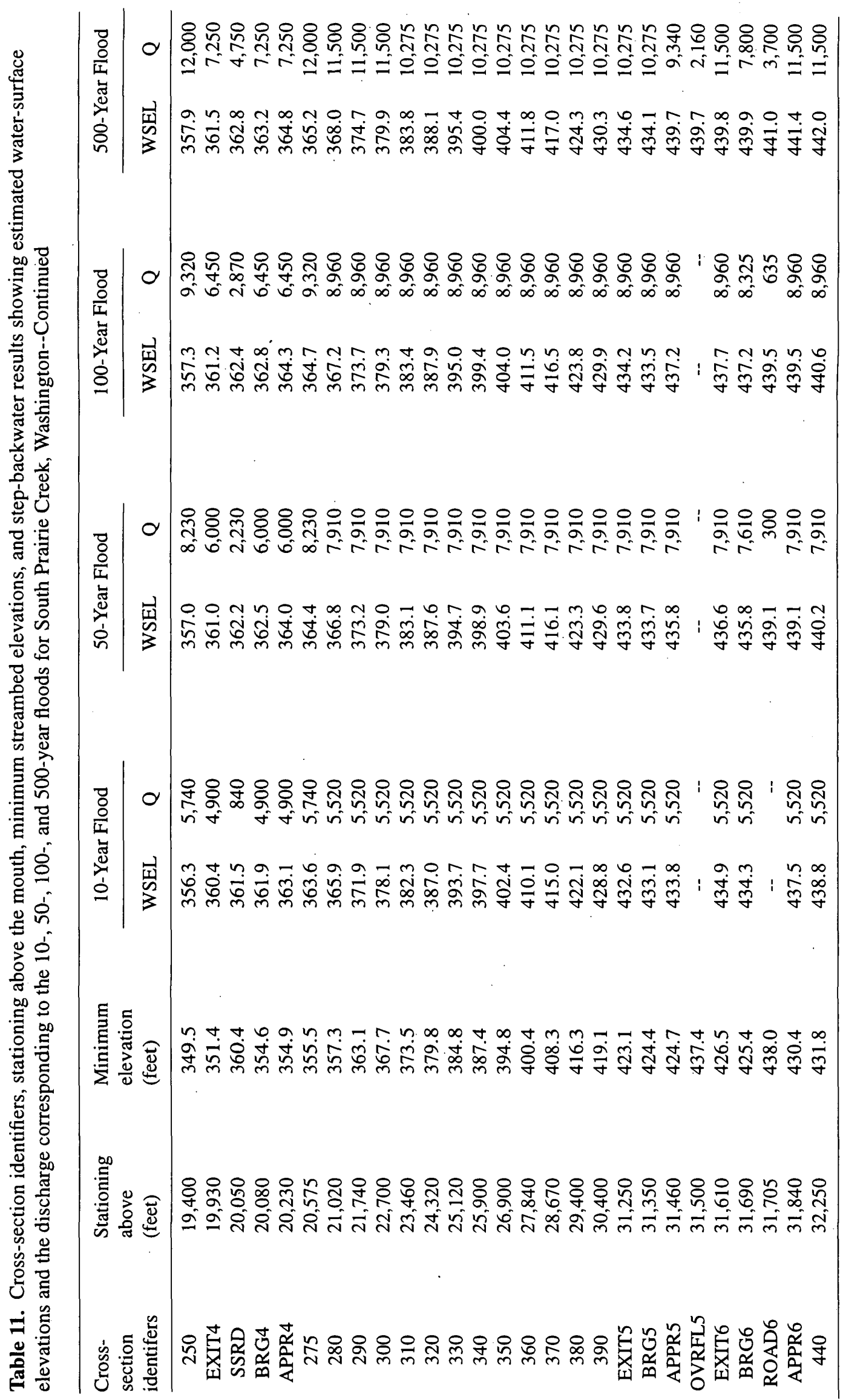




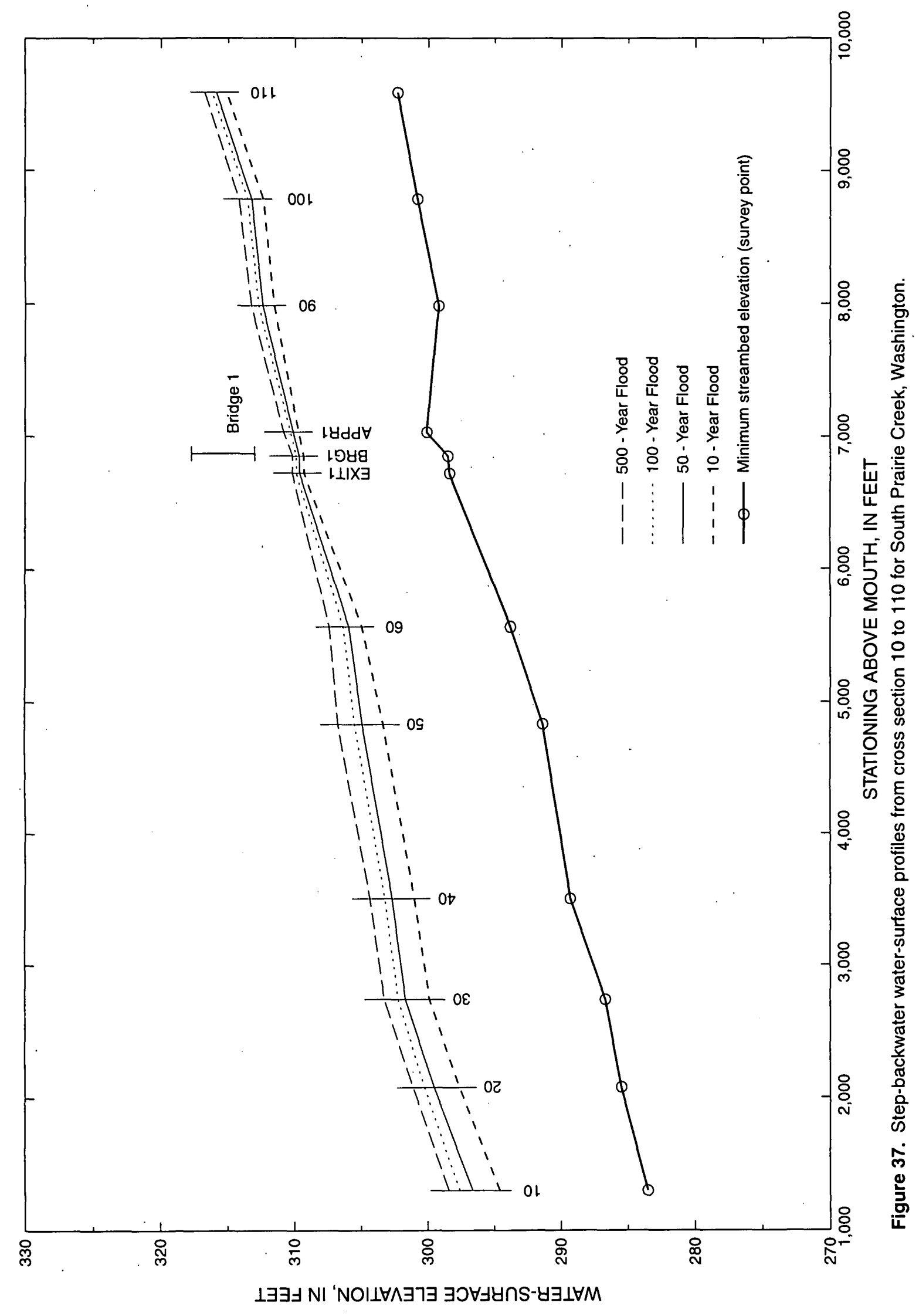




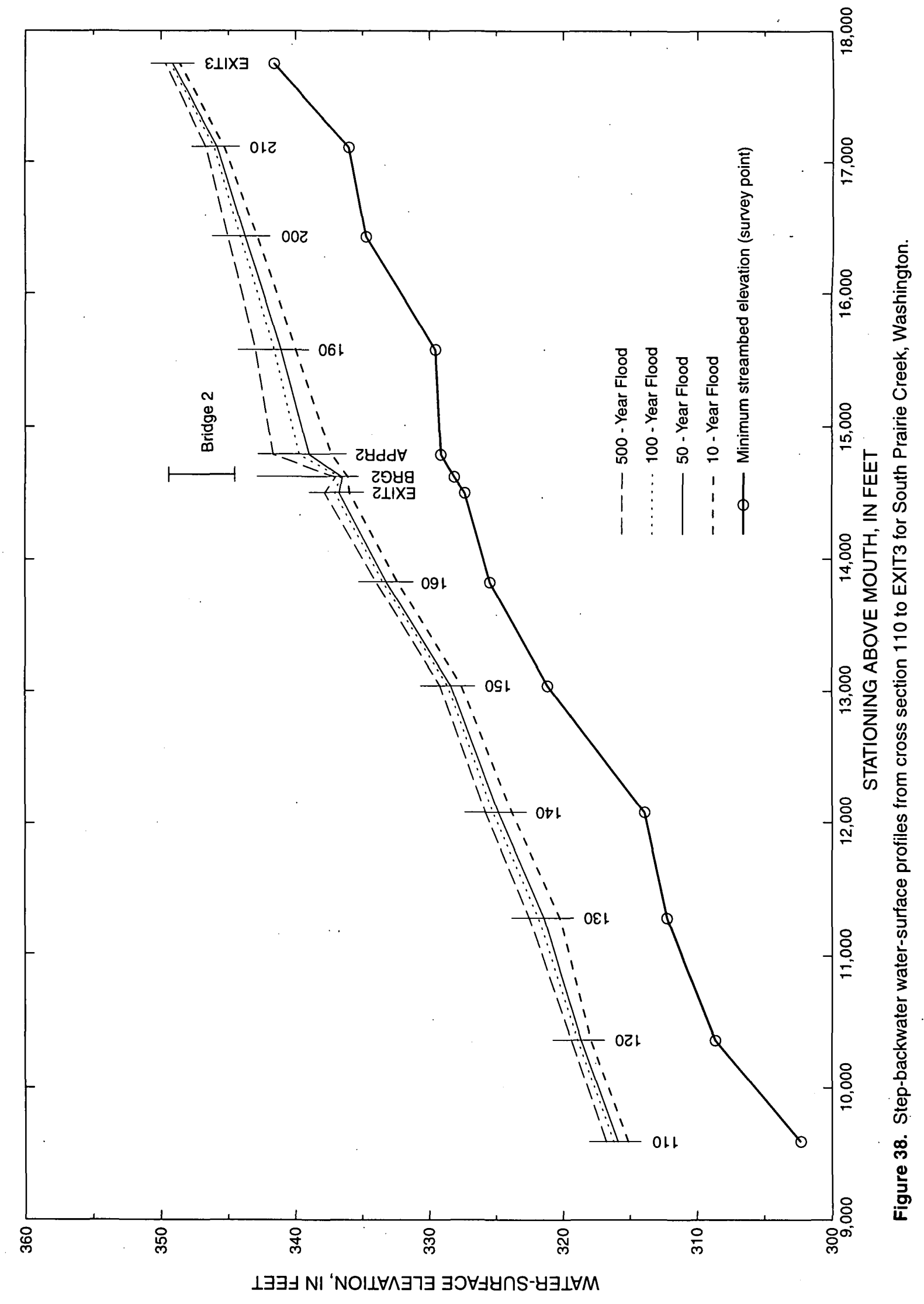




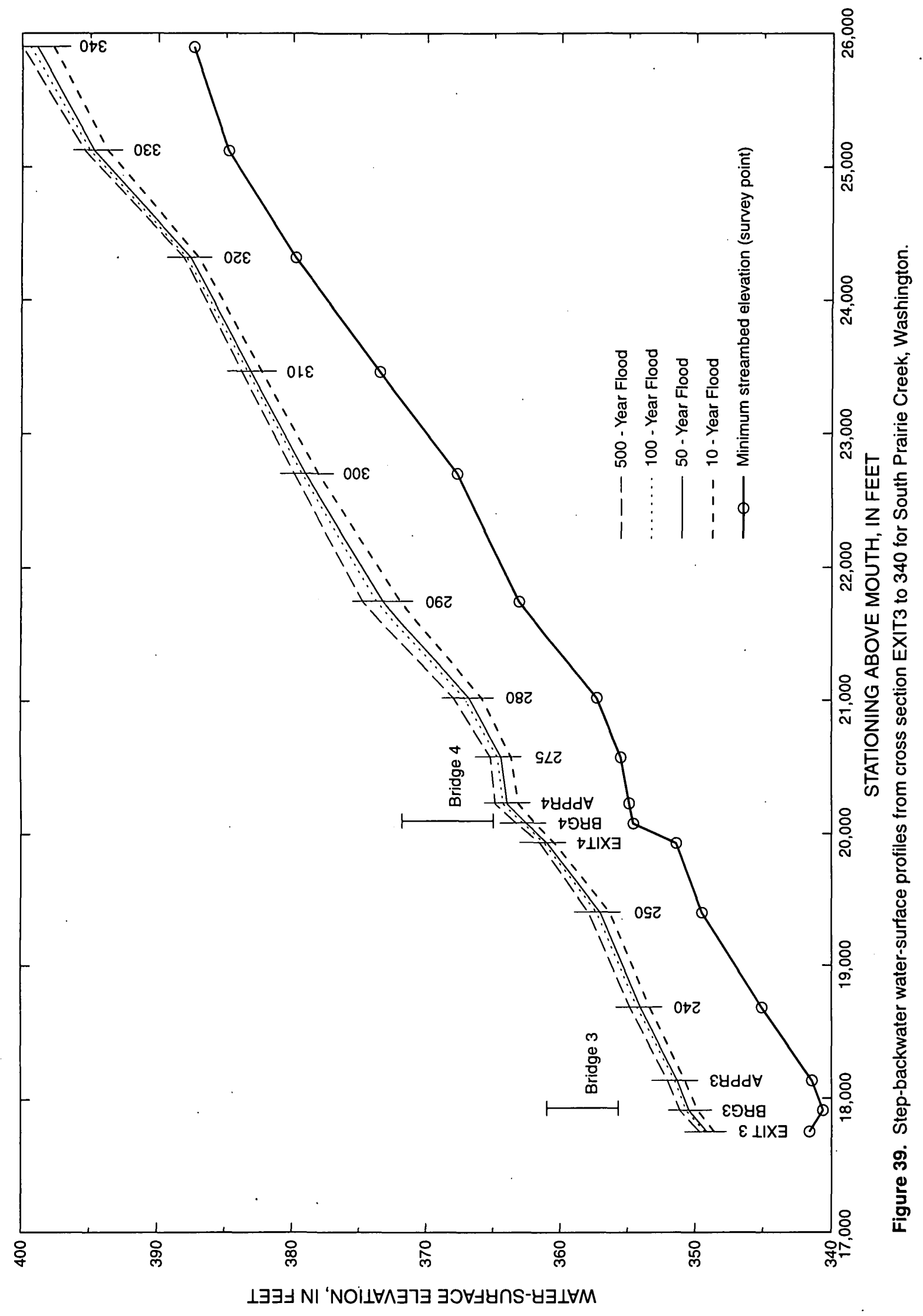




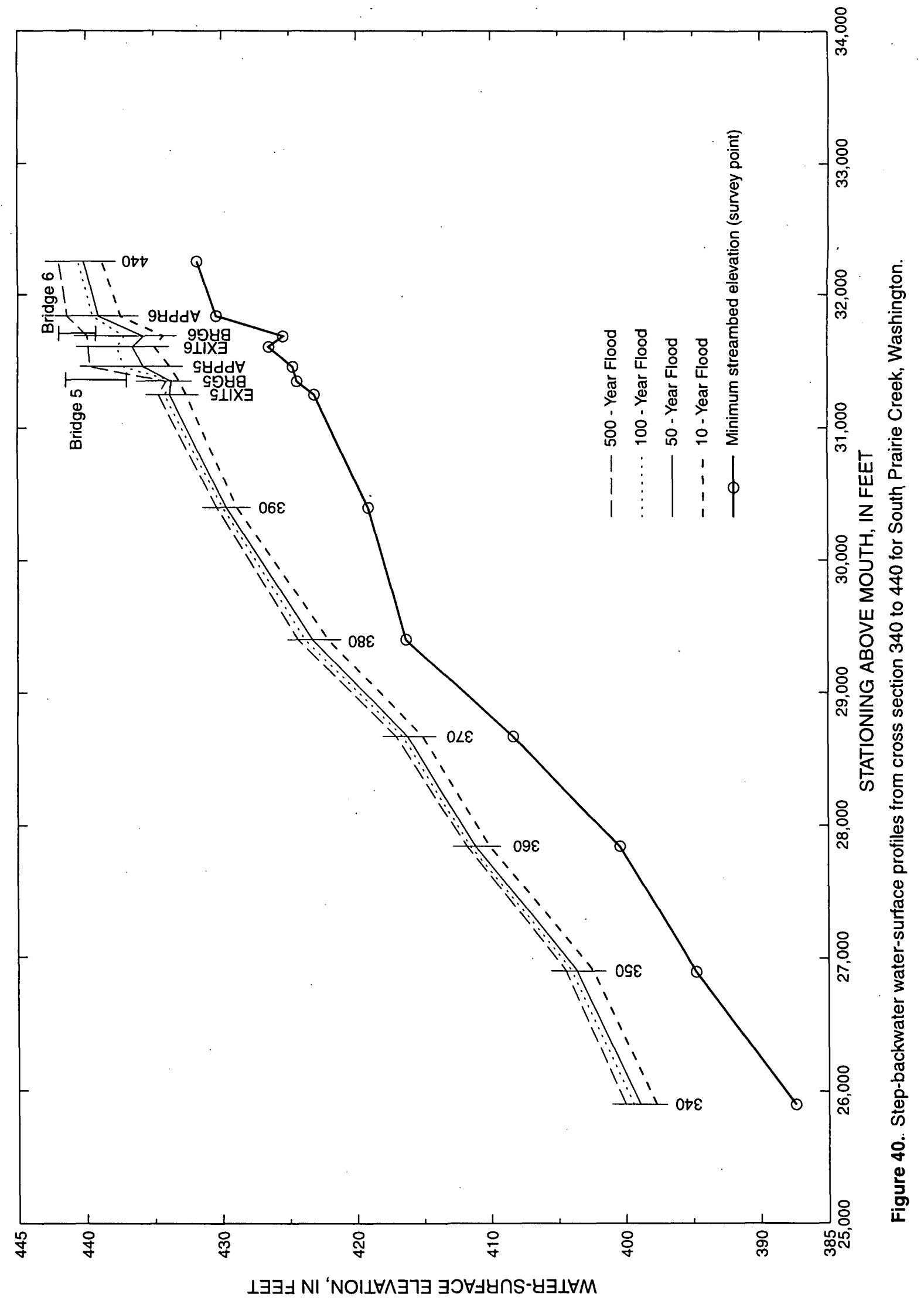




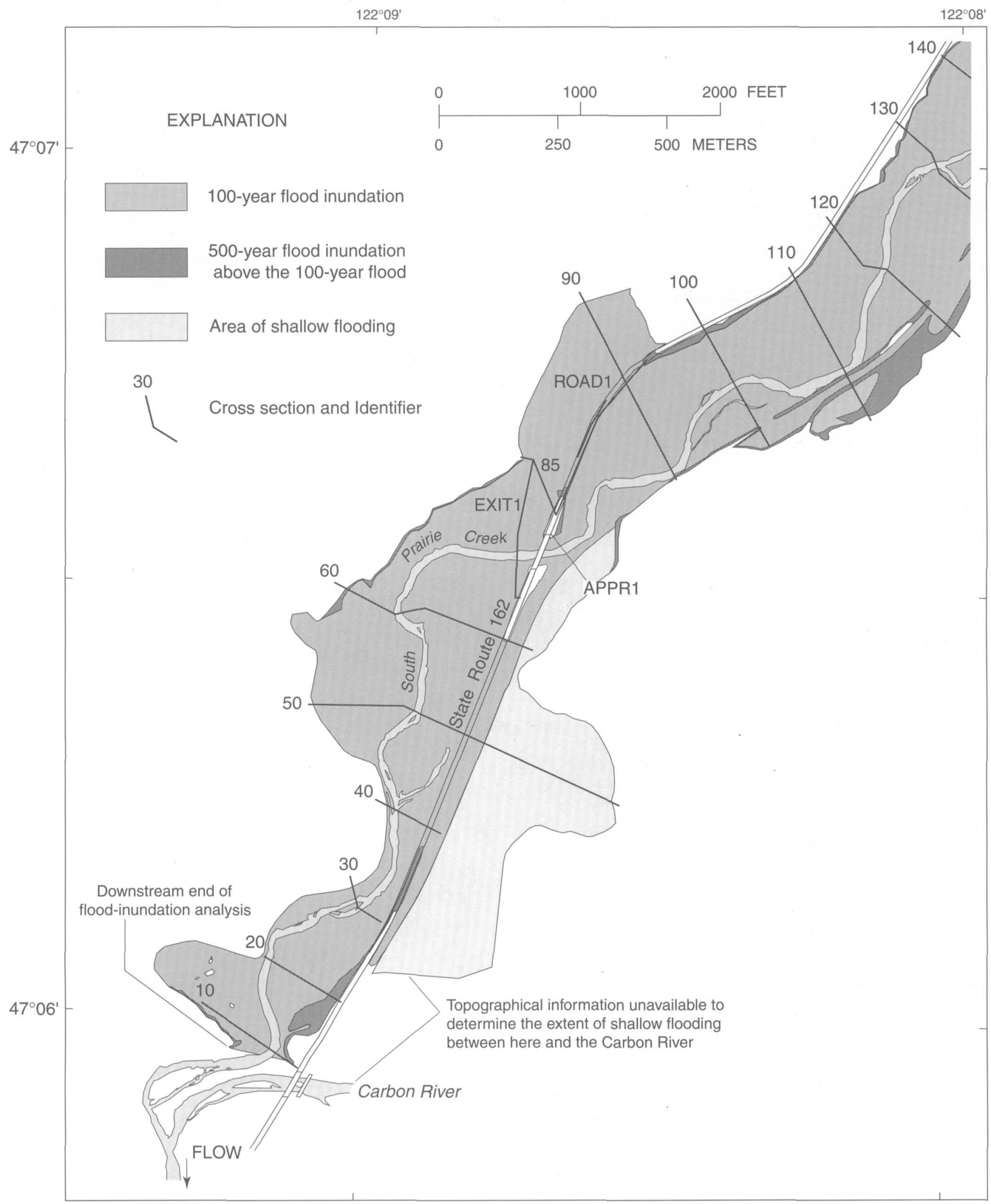

Figure 41. Lower South Prairie Creek, Washington showing area of inundation for the 100and 500-year floods, area of shallow flooding and cross section locations (Map 1 of 4 ). 


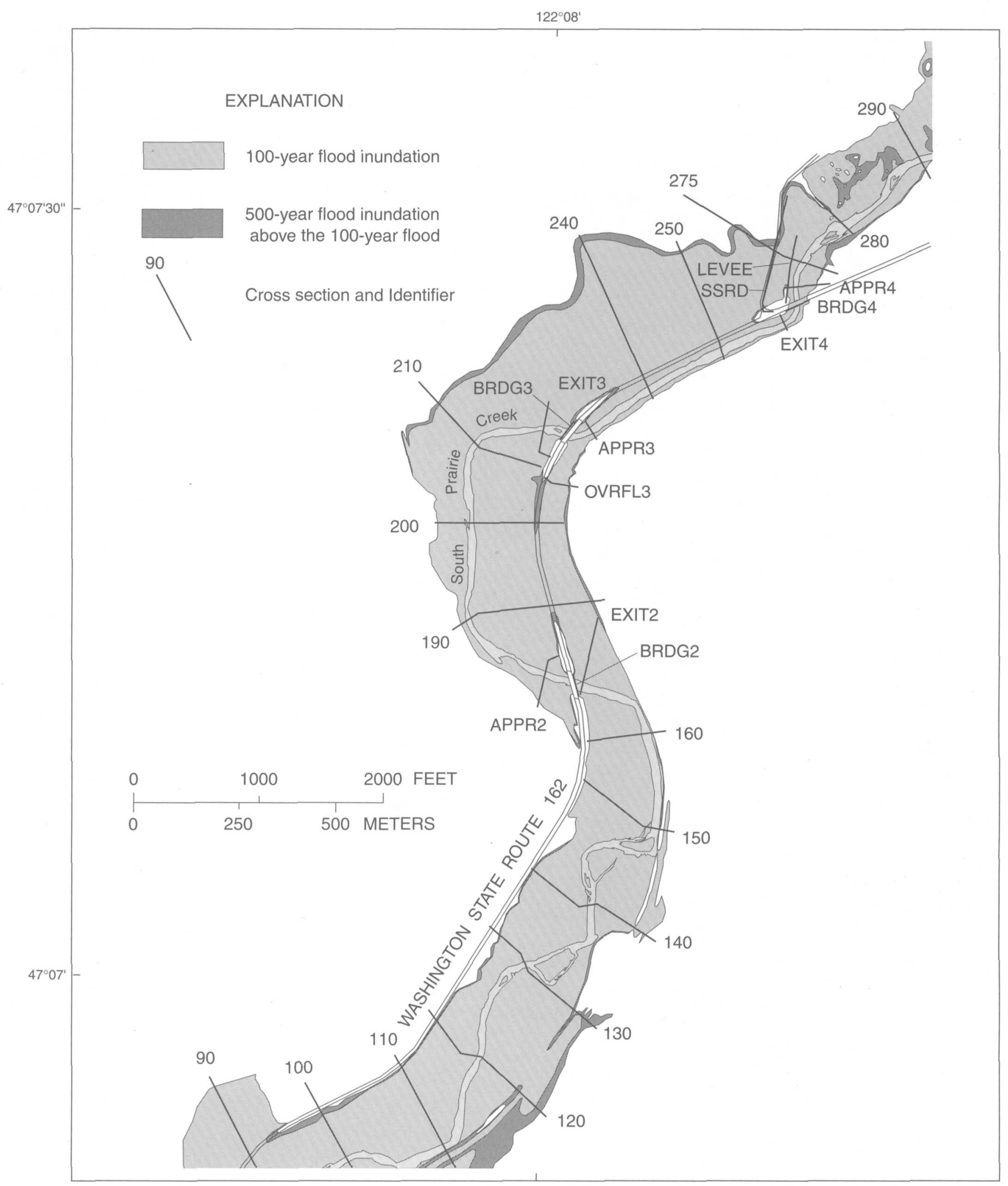

Figure 42. Lower South Prairie Creek, Washington, showing areas of inundation for the 100- and 500- year floods, and cross-section locations (Map 2 of 4). 
$122^{\circ} 07^{\prime}$

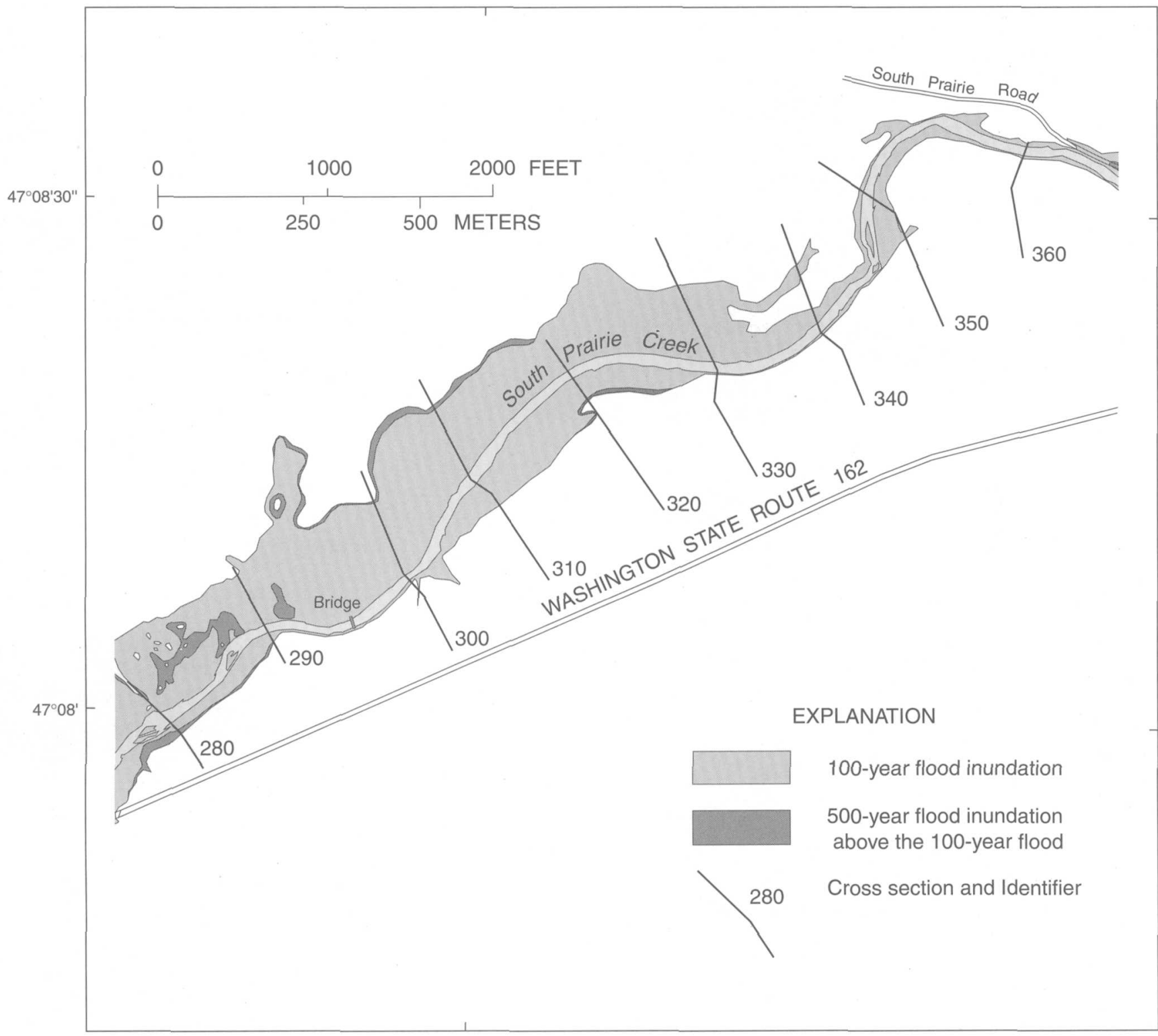

Figure 43. Lower South Prairie Creek, Washington showing area of inundation the 100- and 500-year floods and cross section location (Map 3 of 4). 


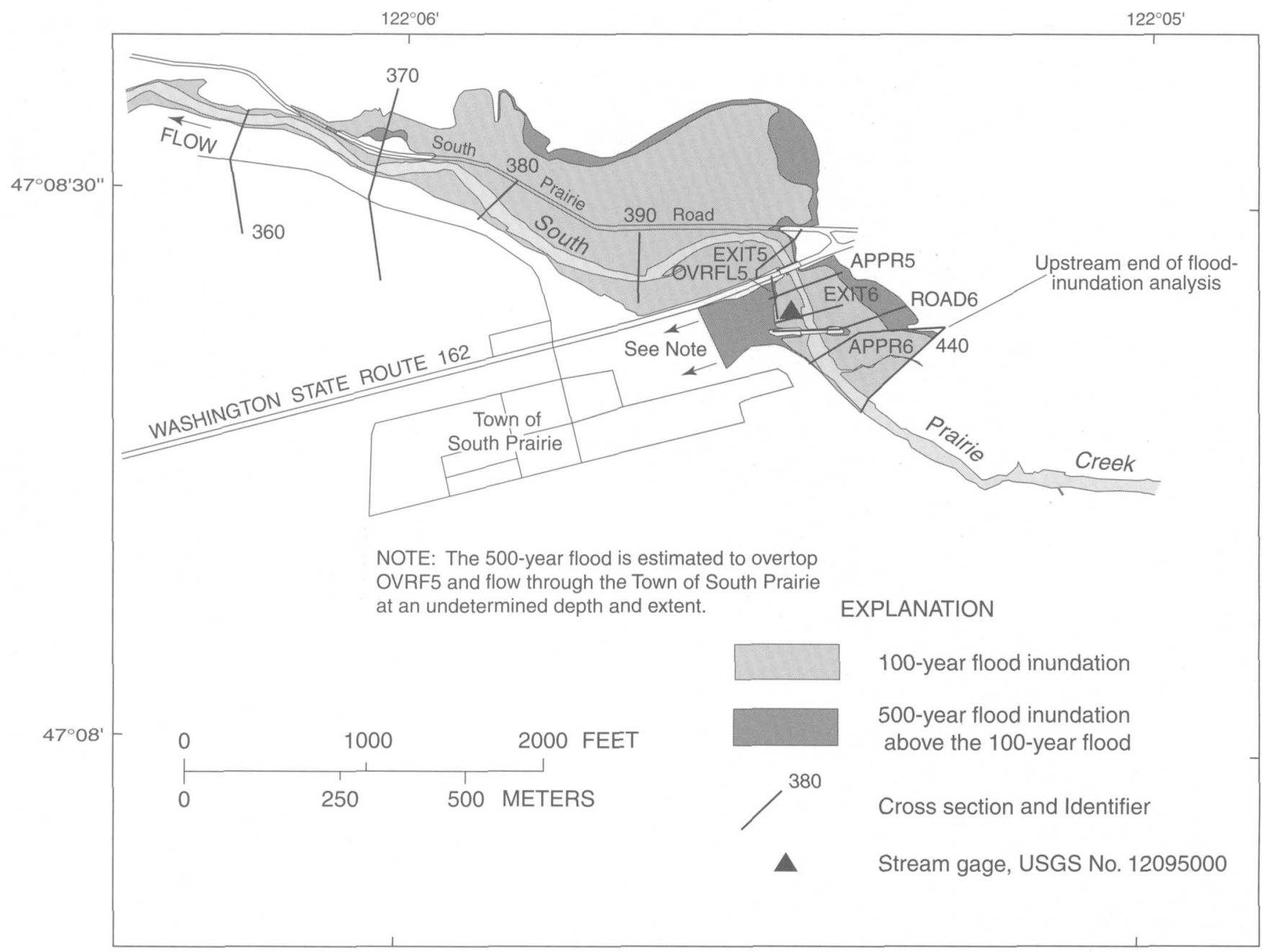

Figure 44. Lower South Prairie Creek, Washington showing area of inundation for the 100-and 500- year floods and cross section locations (Map 4 of 4 ). 


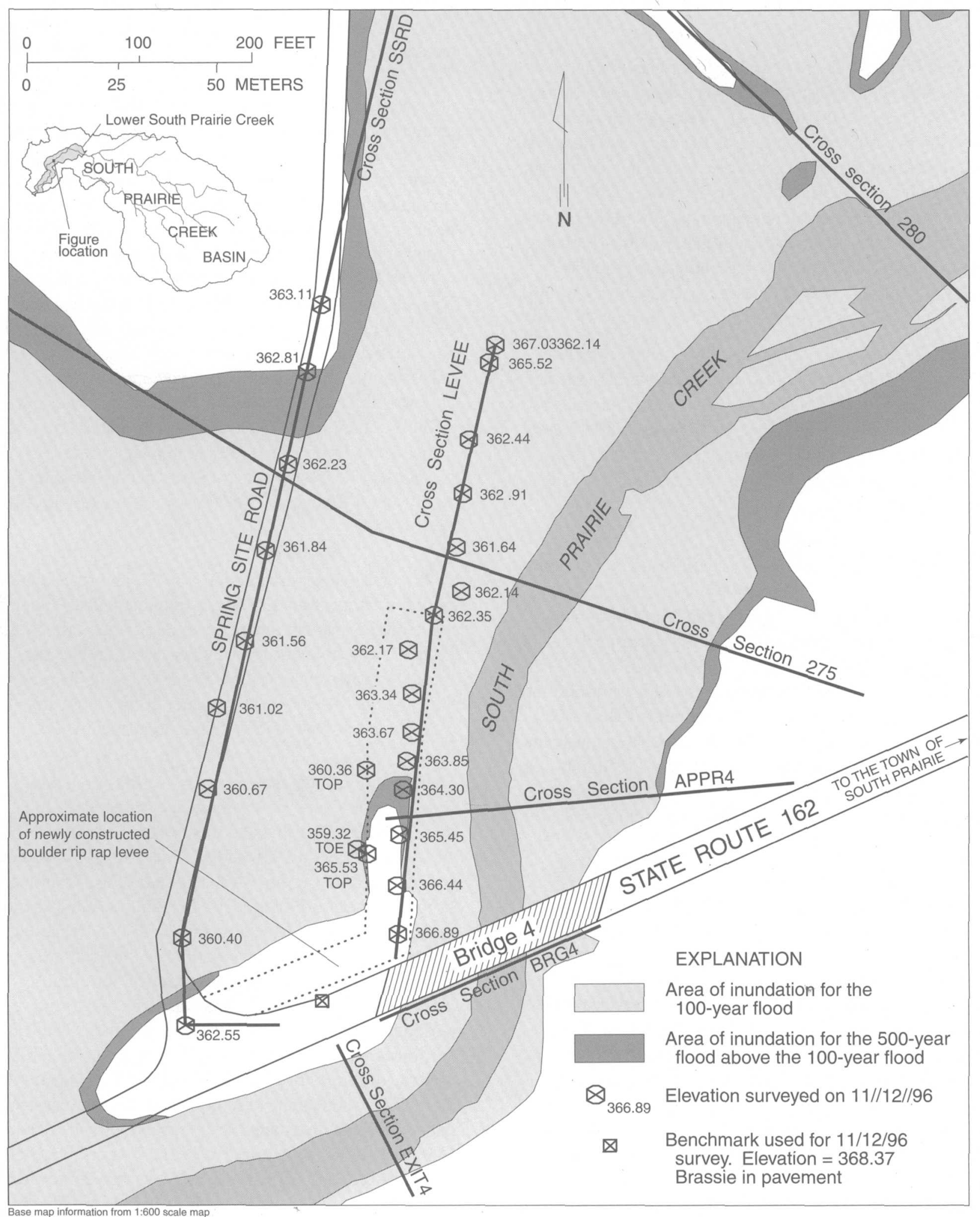

Figure 45. Vicinity of Spring Site Road showing cross sections used in the step-backwater model, the areas of inundation for the 100- and 500-year floods, and elevations surveyed on November 12, 1996. 


\section{SUMMARY}

South Prairie Creek has experienced several large floods in the last few years that have caused some farm, highway, and residential damage. Because of concern about the potential for flooding on the creek and the possibility that flood frequencies have increased in recent years, the U.S. Geological Survey, in cooperation with Pierce County Surface Water Management, reviewed the history of land use in the upper basin and the available discharge data to search for trends that may indicate an increasing potential for flooding in the basin.

Analysis of aerial photo data from 1965 to 1990 indicated that the amount of cleared area increased from 11.2 percent of the total area in 1965 to 34.5 percent in 1990. Road length, which was 119.6 miles in 1965 , grew to 237.0 miles by 1990 . As suggested by current literature, these increases in clearings and road length could increase peak runoff.

Floods in the South Prairie Creek Basin are predominantly caused by relatively long-duration rainfall storms that are often augmented by snowmelt contributions. About one quarter (10 of 39) of the simulated peak discharges had estimated 3-day snowmelt contributions that were at least 30 percent as much as the rain contributions. Most of the floods occurred in the months of December, January, and February after late fall and early winter rainfalls had replenished the soils with water. Precipitation in the basin increases dramatically with elevation, although the relationship varies with the local topography and from storm to storm.

A Mann-Kendall test for trends on the annual peak discharges uncorrected for weather variability showed no trend $($ tau $=-0.012)$. Several meteorological parameters were tested to reduce the variation in the annual peak discharge over time that is caused by the natural variability of weather so that if a trend existed, it could be detected. Precipitation totals at NWS stations, basin-weighted precipitation totals, degree-day indices, snow indices, and snowmelt indices for each of the 39 recorded annual peak discharges at the South Prairie Creek gaging station were regressed against peak discharge to search for a possible variable or combination of variables that would explain much of the natural variability. The best regression was a multiple regression using the basin-weighted precipitation totals and the degree-day index as the explanatory variables $\left(\mathrm{R}^{2}\right.$ adjusted $=0.446$ and Root MSE $\left.=1,240\right)$. The simulated annual peak discharge computed from a water- shed model using long-term meteorological inputs proved to be a better explanatory variable when regressed against annual peak discharge $\left(R^{2}=0.767\right.$ and Root MSE $\left.=814\right)$.

Several statistical trend tests of the annual peak discharges adjusted for natural weather variability showed no statistically significant trend. In a multiple linear regression equation of observed annual peak discharge against simulated annual peak discharge and time, the simulated peak discharge was a significant variable in the regression (p-value less than 0.0001 ), while time was not ( $\mathrm{p}$-value = 0.9141 ), indicating that there is no trend. The MannKendall test for trends was performed on the residuals of the LOWESS fit of observed annual peak discharges with simulated peak discharges (tau $=-0.020)$ and on the residuals from the regression of observed annual peak discharge with simulated annual peak discharge (tau $=$ -0.009). The mean annual number of peaks above a base discharge of $1,400 \mathrm{ft}^{3} / \mathrm{s}$ is greater in recent times (3.3) than in the past (2.5); however, a statistical analysis showed no significant difference at the 5-percent level between the two periods.

Because no significant trend in the record of annual peak discharges was detected, a frequency analysis on the available 39 years of annual peak discharge at the South Prairie Creek at South Prairie gaging station was performed to determine the 10-, 50-, 100-, and 500-year annual-peak discharges. The values computed were 5,$520 ; 7,910 ; 8,960$; and $11,500 \mathrm{ft}^{3} / \mathrm{s}$, respectively.

Floodplain and channel cross sections on lower South Prairie Creek were surveyed at three hydrologically distinct times. The first and most comprehensive survey was done in 1976 and 1977 as part of the Federal Emergency Management Act National Flood Insurance Program (Federal Emergency Managment Act, 1981 and Federal Emergency Managment Act, 1987). It included 51 cross sections from the mouth of South Prairie Creek to a location just upstream of the town of South Prairie. A second set of 28 cross sections was surveyed during the period from October 1994 to December 1995. These cross sections are located for the most part at the same locations as some of the 1976-77 cross sections. Comparison of the 1976-77 baseline data with the second set of cross-section data represents the change over approximately 2 decades. In a third survey soon after the peak of record flood on February 8, 1996,, 13 cross sections were resurveyed at some of the same locations as the 1994-95 surveys (3 more supplemental cross sections were also surveyed where water overflows the main channel banks). A comparison of channel and floodplain cross-section plots surveyed at these three different times from 1976 to 1996 
showed no evidence of significant channel fill that would increase the potential for flooding by reducing the channel flood-carrying capacity.

A step-backwater computer program WSPRO was used with channel cross-section information from surveys in 1976-77, 1995, and 1996 and from a series of topographic maps published in 1987 to determine water-surface profiles along lower South Prairie Creek. The model was calibrated by varying channel roughness parameters so that simulated water-surface elevations matched elevations of two sets of high water marks, one from the February 19, 1995, peak discharge that left marks near the top on the main channel and one from the February 8 , 1996 , peak discharge that left marks on the overbank portion of the cross sections. WSPRO was run for the 10-, 50-, 100-, and 500-year floods to estimate water-surface elevations at all cross sections for each of the discharges, which in turn were used to delineate areas inundated by the 100- and 500-year floods.

The 500-year flood is estimated to overtop its bank and flow around all of the five State Route 162 bridges and the abandoned railroad bridge of lower South Prairie Creek. Flow for the 10-year flood will overtop its bank and flow around three of the State Route 162 bridges. During the 500-year flood, water is expected to overflow the banks just upstream of the State Route 162 bridge in the Town of South Prairie, and anywhere from 1,200 to $2,200 \mathrm{ft}^{3} / \mathrm{s}$ will flow through the town and return to the creek 1.5 miles downstream. Water is expected to slightly overtop the abandoned railroad grade at a spot below the state highway bridge farthest downstream for the 100- and 500-year flood. The railroad grade defines the left bank of the floodplain, and the overflowing water is expected to. flow over a wide area of unknown depth to the Carbon River.

\section{REFERENCES CITED}

Benson, M.A., and Dalrymple, Tate, 1967, General field and office procedures for indirect discharge measurements: U.S. Geological Survey Techniques of Water-Resources Investigation Book 3, Ch. A1, $30 \mathrm{p}$.

Berris, S.N., and Harr, R.D., 1987, Comparative snow accumulation and melt during rainfall in forested and clear-cut plots in the western Cascades of Oregon: Water Resources Research, v.23, no. 1, p 135-142.
Brown, G.W., 1983, Forestry and water quality (2d ed.): Corvallis, Oreg., Oregon State University Book Stores, Inc., $142 \mathrm{p}$.

Burges, S.J., Stoker, B.A., Wigmosta, M.S., and Moeller, R.A., 1989, Hydrologic information and analyses required for mitigating hydrologic effects of urbanization: University of Washington Department of Civil Engineering Water Resources Series Technical Report No. 117, 131 p.

Ca'Zorzi, F., and Dalla Fontana, G., 1986, Improved utilization of maximum and minimum daily temperature in snowmelt modelling, in Morris, E.M., ed., Modelling snowmelt-induced processes, Budapest, Hungary, 1986, Proceedings: International Association of Hydrological Sciences, Publ. no. 155, p. 141-150.

Crandell D.R., 1963, Surficial geology and geomorphology of the Lake Tapps Quadrangle Washington: U.S. Geological Survey Professional Paper 388-A, 84p.

Davidian, Jacob, 1984, Computation of water-surface profiles in open channels: U.S. Geological Survey Techniques of Water-Resources Investigations, book 3, chap. A15, 48 p.

Dunne, Thomas, and Leopold, L.B., 1978, Water in environmental planning: San Francisco, W.H. Freeman and Company, $818 \mathrm{p}$.

Federal Emergency Management Agency, 1981, Town of South Prairie, Washington Pierce County: Washington, D.C., U.S. Federal Emergency Management Agency, 15 p.

1987, Pierce County, Washington unincorporated areas: Washington, D.C., U.S. Federal Emergency Management Agency. v. 1, 81 p.

Fredriksen, R.L., 1970, Erosion and sedimentation following road construction and timber harvest on unstable soils in three small western Oregon watersheds: U.S. Department of Agriculture Research Paper PNW-104,15 p.

Gard, L.M. Jr., 1968, Bedrock geology of the Lake Tapps Quadrangle[,] Pierce County[,] Washington: U.S. Geological Survey Professional Paper 388-B, 33 p. 
Harr, R.D., 1981, Some characteristics and consequences of snowmelt during rainfall in western Oregon: Journal of Hydrology, v. 53, p. 277-304.

1986, Effects of clearcutting on rain-on-snow runoff in western Oregon: A new look at old studies: Water Resources Research, v. 22, no. 7, p. 1095-1100.

Harr, R.D., Harper, W.C., and Krygier, J.T., 1975, Changes in storm hydrographs after road building and clear-cutting in the Oregon Coast Range: Water Resources Research, vol. 11, no. 3, p. 436-444.

Helsel D.R., and Hirsch, R.M., 1995, Statistical methods in water resources: Studies in Environmental Science, v. 49,529 p.

Hewlett, J.D., and Hibbert, A.R., 1967, Factors affecting the response of small watersheds to precipitation in humid regions, in Sopper, W.E., and Lull, H.W., ed., Forest hydrology: Oxford, Pergamon Press, p. 275-290.

Hulsing, Harry, 1984, Measurement of peak discharge at dams by indirect methods: U.S. Geological Survey Techniques of Water-Resources Investigations, book 3, chap. A5, 29 p.

Jones, J.A., and Grant, G.E., 1996, Peak flow responses to clear-cutting and roads in small and large basins, western Cascades, Oregon: Water Resources Research, v. 32, no. 4, p. 959-974.

Likens, G.E., Bormann, F.H., Johnson N.M., Fischer D.W., and Pierce R.S., 1970, Effects of forest cutting and herbicide treatment on nutrient budgets in the Hubbard Brook watershed-ecosystem in Ecological Monographs v. 40, no. 1, p.24-46.

Linsley, R.K., Kohler, M.A., and Paulhus, J.L., 1982, Hydrology for engineers: San Francisco, McGraw-Hill Book Company, 508 p.

Office of Financial Management, Washington State 1991 data book: Olympia, Wash., Washington State Office of Financial Management, $306 \mathrm{p}$.

Ott, Lyman, 1993, An introduction to statistical methods and data analysis: Belmont, California, Wadsworth Publishing Company, $1051 \mathrm{p}$.
Rosencrantz, S.D., Storck, Pascal, and Lettenmaier, D.P., 1996, Statistical analysis of logging effects on flooding in the Snoqualmie River basin, Washington: Seattle Wash., University of Washington, hydrology home page, on-line on the World Wide Web from URL http://www.ce.washington.edu/ hydro/ Lettenmaier/Publications/small_watershed/ poster.html, accessed August 14, 1996.

Rothacher, Jack, 1970, Increases in water yield following clear-cut logging in the Pacific Northwest: Water Resources Research, v.6, no. 2, p. 653-658.

Shearman, J.O., Kirby, W.H., Schneider, V.R., and Flippo, H.N., 1986, Bridge waterways analysis model-research report: U.S. Federal Highway Administration Report No. FHWA/RD-86/108, 112 p

Soil Conservation Service [now the National Resource Conservation Service], 1965, [Map of] Mean Annual Precipitation 1930-1957 State of Washington: Portland, Oregon, Soil Conservation Service, 1 p.

U.S. Army Corps of Engineers, 1956, Snow hydrology--summary report of the snow investigations: Portland, Oreg., North Pacific Division, U.S. Army Corps of Engineers, 437 p.

1991, User manual SSARR model streamflow synthesis and reservoir regulation: Portland, Oreg., North Pacific Division, U.S. Army Corps of Engineers.

U.S. Department of Commerce, 1973, Precipitationfrequency atlas of the western United States, volume D--Washington: Silver Spring, Md, National Oceanic and Atmospheric Administration, NOAA Atlas 2, $43 \mathrm{p}$.

U.S. Water Resources Council, 1981, Guidelines for determining floodflow frequency: U.S. Water Resources Council Bulletin 17B, 183 p.

van Heeswijk, M., Kimball, J.S., and Marks, Danny, 1996, Simulation of water available for runoff in clearcut forest openings during rain-on-snow events in the western Cascade Range of Oregon and Washington: U.S. Geological Survey Water-Resources Investigations Report 95-4219, 67p. 
Wright, K.A., Sendek, K.H., Rice, R.M., and Thomas, R.B., 1990, Logging effects on streamflow-- storm runoff at Caspar Creek in northwestern California: Water Resources Research, v. 26, no. 11, p. 1657-1667. 